INTER NATIONAL MONETARY FUND
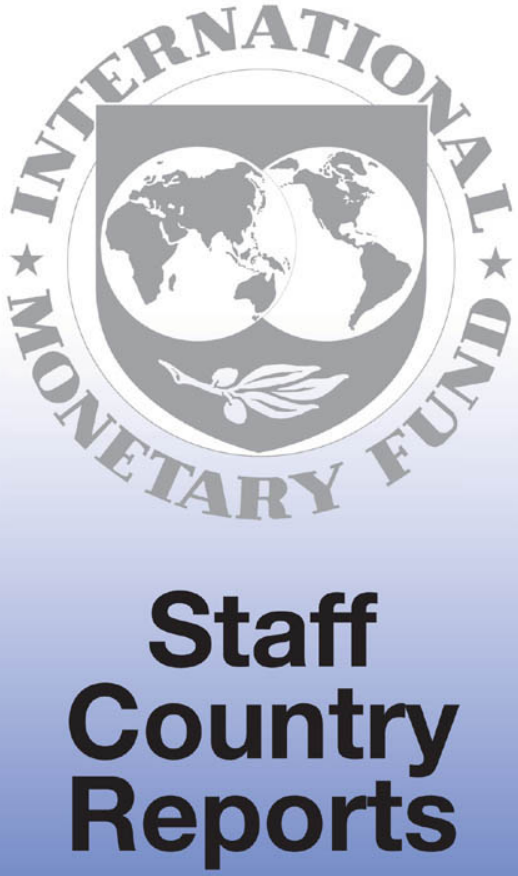


\title{
South Africa: 2008 Article IV Consultation-Staff Report; Staff Statement; Public Information Notice on the Executive Board Discussions; and Statement by the Executive Director for South Africa
}

Under Article IV of the IMF's Articles of Agreement, the IMF holds bilateral discussions with members, usually every year. In the context of the Article IV consultation with South Africa, the following documents have been released and are included in this package:

- The staff report for the 2008 Article IV consultation, prepared by a staff team of the IMF, following discussions that ended on July 1, 2008 with the officials of South Africa on economic developments and policies. Based on information available at the time of these discussions, the staff report was completed on August 15, 2008. The views expressed in the staff report are those of the staff team and do not necessarily reflect the views of the Executive Board of the IMF.

- $\quad$ A staff statement of September 8, 2008 updating information on recent developments.

- $\quad$ A Public Information Notice (PIN) summarizing the views of the Executive Board as expressed during its September 8, 2008 discussion of the staff report that concluded the Article IV consultation.

- $\quad$ A statement by the Executive Director for South Africa.

The documents listed below have been or will be separately released.

Selected Issues Paper

Financial System Stability Assessment

The policy of publication of staff reports and other documents allows for the deletion of market-sensitive information.

\author{
Copies of this report are available to the public from \\ International Monetary Fund $\bullet$ Publication Services \\ $70019^{\text {th }}$ Street, N.W. • Washington, D.C. 20431 \\ Telephone: (202) 623-7430 • Telefax: (202) 623-7201 \\ E-mail: publications@imf.org Internet: http://www.imf.org
}

Price: $\$ 18.00$ a copy

\section{International Monetary Fund Washington, D.C.}


This page intentionally left blank

CInternational Monetary Fund. Not for Redistribution 
INTERNATIONAL MONETARY FUND

SOUTH AFRICA

Staff Report for the 2008 Article IV Consultation

Prepared by Staff Representatives for the 2008 Consultation with South Africa

Approved by Saul Lizondo and Adnan Mazarei

August 15, 2008

\section{Executive Summary}

Background: After several years of relatively high growth, a number of shocks are slowing growth, while pushing inflation and the current account deficit up. Global increases in food and fuel prices have pushed inflation into double digits, while strong investment, including an ambitious public investment program, is contributing to a worrisome widening of the external current account deficit. Policies remain broadly appropriate, with substantial monetary tightening and a small fiscal surplus aiming to moderate domestic demand. The financial sector is sound and well regulated, but now faces a less benign environment.

Challenges: In the near term, it will be critical to preserve macroeconomic stability by containing inflation and addressing external vulnerabilities so that the push to accelerate growth and spur job creation will not be derailed. More fundamentally, higher output and employment growth are needed to reduce still high unemployment and inequality.

Staff views: Risks to macroeconomic stability have increased with rising inflation and the widening current account deficit, the financing of which has become less assured. Further monetary tightening may be needed to prevent second-round effects from the food and fuel price shocks. Given the large public infrastructure program and low private saving, a gradual increase in the structural fiscal balance would avoid exacerbating current account pressures and bolster confidence. In the medium term, increases in saving and investment, deficitneutral tax and spending policies to strengthen incentives to invest and work, and structural reforms to boost competitiveness and productivity could raise growth and employment.

Authorities' views: While broadly sharing staff's assessment, the authorities were more optimistic regarding risks to external stability as they consider markets to be willing to finance the investment-driven increase in the current account deficit, which they also expect to be somewhat lower than staff's projections. They felt they had little alternative but to increase public investment to address critical infrastructure bottlenecks and noted there was little leeway and support for increasing government saving. The SARB indicated its intention to tighten monetary policy as needed to anchor inflation expectations. 
Glossary

I. Background: Strong Macroeconomic Performance and Rising Challenges

II. Discussions on the Outlook: A Slowing Economy with Increasing Downside Risks ...........

III. Policy Discussions

A. Containing Inflation Pressures .....................................................................11

B. Addressing Vulnerabilities ...........................................................................

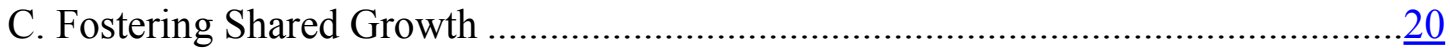

D. Regional Integration...................................................................................

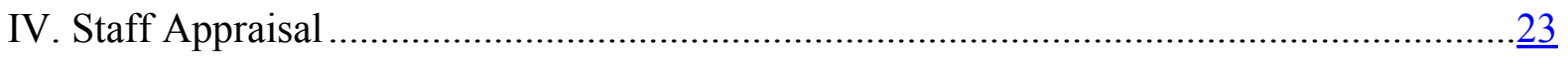

Tables

1. Selected Economic and Financial Indicators …………...............................................

2. Selected Economic and Financial Indicators in the Medium Term ...................................27

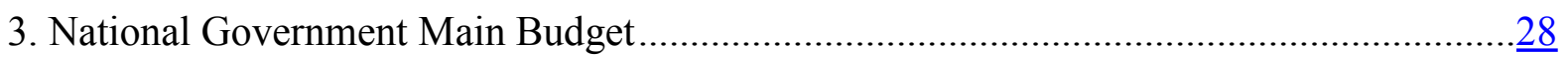

4. Nonfinancial Public Sector Operations..........................................................................29

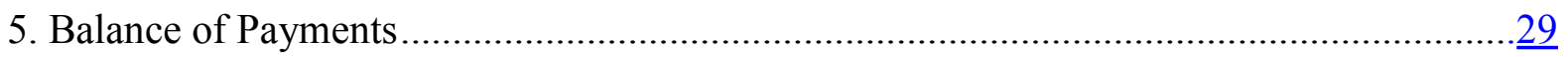

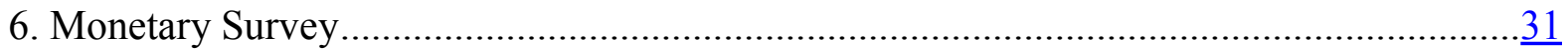

7. Indicators of External Vulnerability …………………..............................................

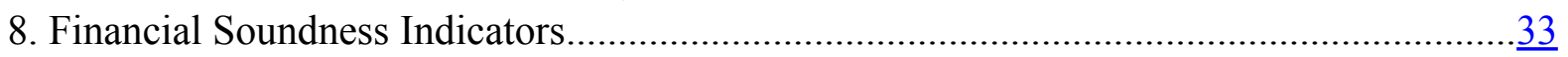

9. Social and Demographic Indicators ……...............................................................

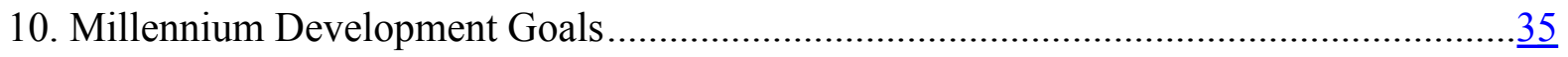

Figures

1. Real Sector Developments .......................................................................................

2. Exchange Rates, Asset Prices, and Spreads ……………..............................................

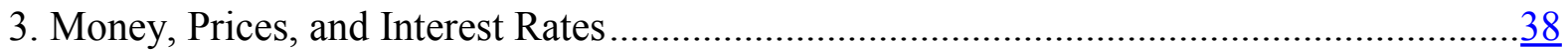

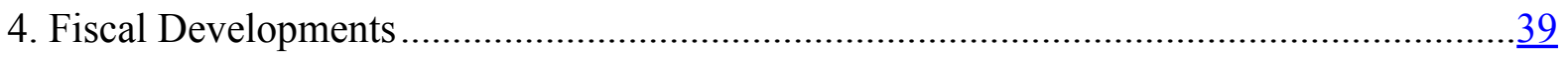

Boxes

1. South Africa's Power Crisis.............................................................................................

2. Current Account Vulnerabilities .................................................................................

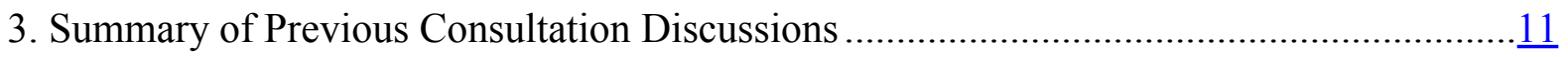

4. Risks from Rising Household Debt …………….......................................................

5. The Real Exchange Rate and Competitiveness ………………………….....................

Appendix

I. Debt Sustainability Analysis ....................................................................................... 


\section{GLOSSARY}

\begin{tabular}{ll} 
ANC & African National Congress \\
ASGISA & Accelerated and Shared Growth Initiative for South Africa \\
CAB & Current Account Balance \\
CAD & Current Account Deficit \\
CGER & Consultative Group on Exchange Rate Issues \\
CPI & Consumer Price Index \\
CPIX & CPI excluding the interest on mortgage loans \\
EMEs & Emerging Market Economies \\
EPA & Economic Partnership Agreement \\
EU & European Union \\
FDI & Foreign direct investment \\
FSAP & Financial Sector Assessment Program \\
FSSA & Financial Sector Stability Assessment \\
IFS & International Financial Statistics \\
MPC & Monetary Policy Committee \\
NPL & NonPerforming Loans \\
PSBR & Public Sector Borrowing Requirement \\
REER & Real Effective Exchange Rate \\
SACU & Southern African Customs Union \\
SADC & Southern African Development Community \\
SARB & South African Reserve Bank \\
SDDS & Special Data Dissemination Standard \\
SOEs & State-owned enterprises \\
TFP & Total Factor Productivity \\
WDI & World Development Indicators \\
WEO & World Economic Outlook \\
\hline
\end{tabular}




\section{Background: Strong Macroeconomic Performance and Rising Challenges ${ }^{1}$}

1. South Africa has made strong economic progress in the past several years. Good macroeconomic management and favorable external conditions raised growth to 5-51/2 percent in 2005-07, lowered inflation to mid-single digits until recently, strengthened the public finances, and improved the external reserve position (Figure 1). Employment grew steadily, allowing the unemployment rate to decline from over 30 percent in 2002 to 23 percent by 2007 . The expansion was led by strong domestic demand. Household consumption was driven by growing disposable income and wealth effects from rising housing and stock prices, while private investment was buoyed by strong business confidence and high commodity prices.

2. At the same time, South Africa has continued to face difficult challenges in overcoming its apartheid legacy and addressing high levels of unemployment and inequality. Unemployment is high in part because of the strong increase in labor force participation following the end of apartheid, and also because various factors, such as weak product market competition, have supported a two-tier labor market comprising relatively well-paid formal sector workers and others - particularly less-skilled black workers - who have been excluded from employment altogether. ${ }^{2}$ Nevertheless, labor force participation remains low by international comparison and growth, although rising, has trailed behind rates in dynamic emerging market economies (EMEs). Income inequality remains among the most acute in the world, highlighting the pressing need to ensure that growth is shared broadly, as underscored by the government.

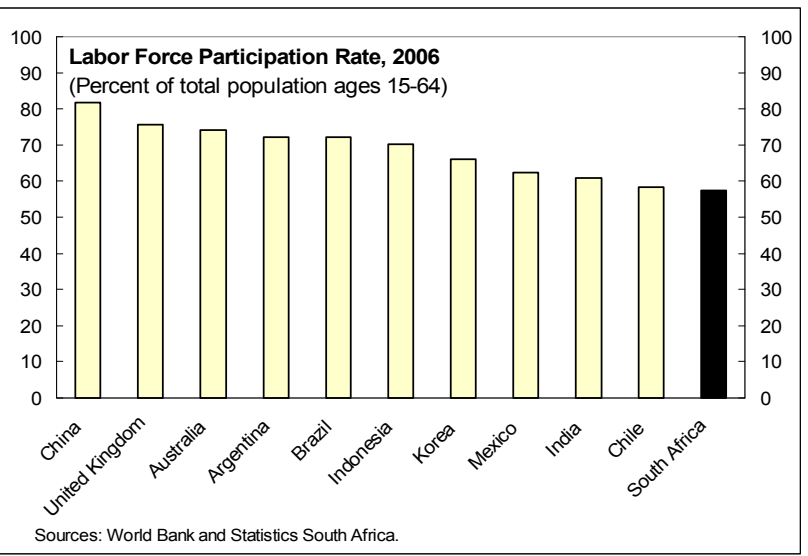

\begin{tabular}{|lccc|}
\hline \multicolumn{4}{|c|}{ Income Distribution, latest year } \\
\hline & \multirow{4}{*}{ Gini Index 1 } & Share of Income Held By: \\
\cline { 3 - 4 } & & Top 20\% & Bottom 20 \% \\
\hline South Africa & $\mathbf{5 8}$ & $\mathbf{6 2 . 2}$ & $\mathbf{3 . 5}$ \\
Brazil & 57 & 60.8 & 2.9 \\
Chile & 55 & 60.0 & 3.8 \\
Argentina & 51 & 55.4 & 3.1 \\
China & 47 & 51.9 & 4.3 \\
Mexico & 46 & 55.1 & 4.3 \\
Indonesia & 39 & 47.3 & 7.1 \\
India & 37 & 45.3 & 8.1 \\
United Kingdom & 36 & 44.0 & 6.1 \\
Australia & 35 & 41.3 & 7.9 \\
Korea & 32 & 37.5 \\
\hline \multicolumn{4}{|l}{} \\
Source: World Bank, World Development Indicators. \\
A measure of distribution of income or consumption, where 0 represents perfect equality \\
and 100 represents perfect inequality.
\end{tabular}

\footnotetext{
${ }^{1}$ The discussions were held during June 18-July 1, 2008. The mission met with the Minister of Finance, the Deputy Governor of the South African Reserve Bank, senior officials, and representatives from Parliament, the private sector, trade unions, and the academic community. The staff team comprised Ms. Corey (head), Messrs. Cuevas, Gueorguiev, and Eyraud (all AFR), and Ms. Nkusu (PDR). Messrs. Nolan and Burgess, resident representatives in Pretoria, participated in the mission. Mr. Wajid (MCM) joined the mission to discuss the conclusions of the FSAP Update. Mr. Aboobaker (OED) also attended the meetings.

${ }^{2}$ OECD, Economic Assessment of South Africa, July 2008.
} 
3. President Mbeki's government is in its final year in office, with national elections expected in April 2009. The leadership of the ruling African National Congress (ANC) experienced a major turnover in December 2007, with many incumbents losing office. The new leadership, headed by former Deputy President Jacob Zuma, has underscored the party's commitment to policy continuity in key areas.

4. Since the beginning of 2008, the South African economy has been buffetted by a series of shocks.

- In January, power cuts disrupted output and exports (particularly in mining), taking the public by surprise (Box 1). Continuing power rationing is expected to constrain output growth until additional generation capacity is brought on stream over several years.

- The global financial market turmoil in early 2008 heightened investors' sensitivity to South Africa-specific risk, reflecting concerns about the power crisis, the rising current account deficit (9 percent of GDP in 2008Q1), and the impending political transition. Risk premia on South African debt increased and portfolio inflows turned negative, weakening the stock market index and the rand, which depreciated by about 20 percent between end-2007 and mid-March, before recovering somewhat (Figure 2).

- Global food and fuel price shocks intensified, leading to sharp increases in consumer price inflation (11.6 percent in June) and inflation expectations.

\section{Recent indicators point to a} slowdown in activity reflecting the cumulative effect of power shortages, the global slowdown, and past monetary tightening. Growth of manufacturing and mining output has weakened; retail and vehicle sales have contracted; and residential property price growth has slowed to low single digits. Business and consumer confidence indices now point to
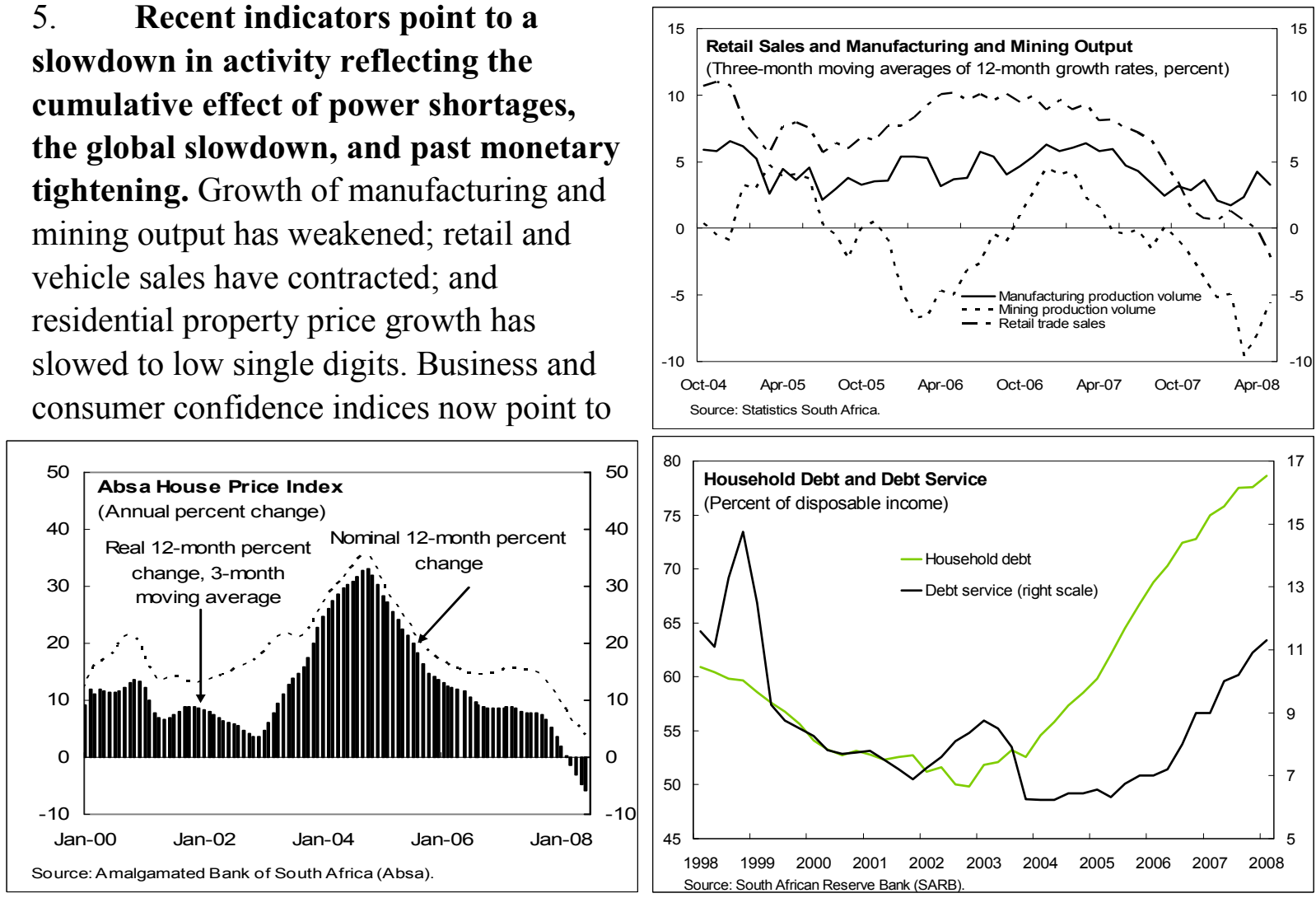
a weakening economy. The expansion in credit to the private sector has moderated somewhat, partly reflecting stricter lending standards introduced in June 2007. Households' debt has reached a record high, while the continued rise in debt service-largely reflecting the rise in mortgage interest rates - has dampened consumption. Investment, however, remains strong reflecting in part higher public infrastructure spending.

\section{Box 1. South Africa's Power Crisis}

South Africa has long produced low-cost electricity, reflecting its abundant coal reserves. Electricity prices have been among the lowest in the world, some 60 percent below the average price in major economies - a key factor in the development of energy-intensive mining and mineral processing sectors.
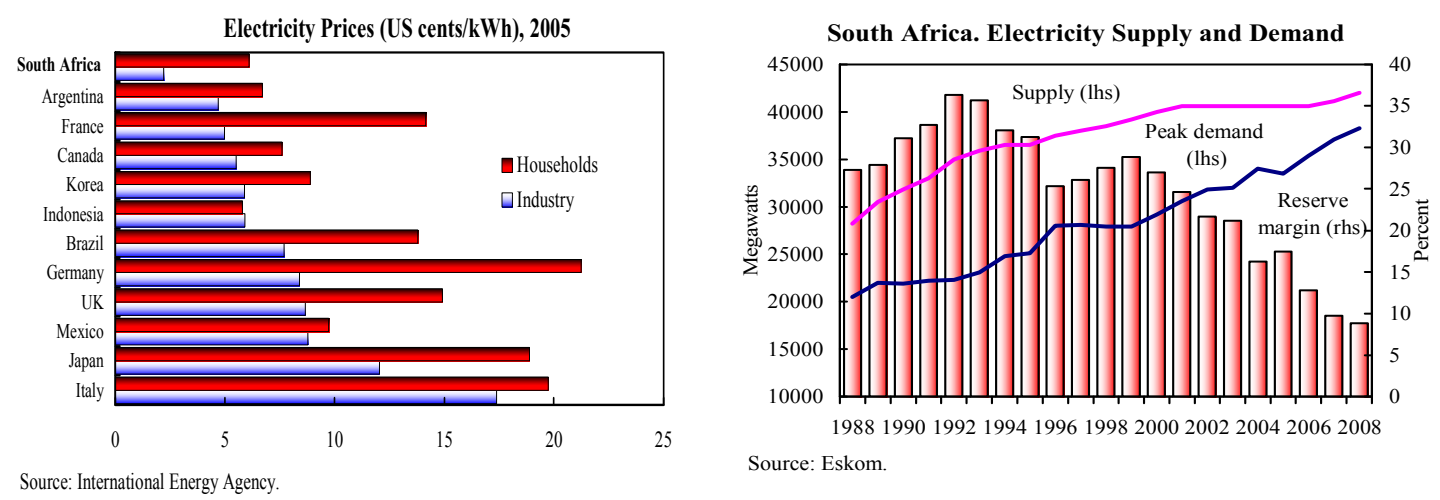

South Africa's electricity-generating capacity has stagnated in recent years while demand has continued to rise. Private investment in generation did not materialize, partly because electricity tariffs were set too low to provide the returns sought by investors, while investment by the state-owned electricity provider Eskom was delayed. As a result, the reserve margin in the system has declined, causing periodic power cuts. In January 2008, unplanned emergency maintenance and a drop in coal stocks forced power cuts to large industrial users for the first time, leading to a temporary shutdown of mining production.

The government's response to the crisis aims to reduce demand by about 10 percent until new capacity comes on stream. Most large mines and other industrial customers remain rationed to 90-95 percent of their normal electricity needs. Eskom's plans include an ambitious increase in its generating capacity by some 50 percent over the next $9-10$ years. Electricity prices have been raised by $271 / 2$ percent on average since July 1, 2008 and are set to increase substantially over the next several years to help finance rising costs of operation and investment, while promoting conservation. Nevertheless, the supply-demand balance is likely to remain tight for the next few years, with significant risk of power disruptions. 
6. A critical challenge in the period ahead will be to ensure that possible instability related to the current account deficit does not derail the push to accelerate growth and spur job creation. Within this overarching theme, discussions focused on:

- assessing the economic outlook and risks;

and policies to:

- contain inflation in the face of successive large global food and fuel price shocks and slowing growth;

- address vulnerabilities, including by ensuring the health of the financial sector, reflecting the Financial Sector Assessment Program (FSAP) Update; ${ }^{3}$ and

- foster shared growth by addressing the main constraints to growth.

\section{Discussions on the Outlook: A Slowing Economy With INCREASING DOWNSIDE RISKS}

7. The short-term outlook for South Africa has weakened over the last year. Staff projects output growth to moderate to below 4 percent in 2008 and 2009 due to power supply constraints, lower demand in partner countries, and the cumulative effect on consumption of previous monetary policy tightening. Inflation is expected to peak later this year and to remain above the target band for a significant period, reflecting the pass-through of higher food, fuel and electricity prices as well as second-round effects. Despite slowing private consumption growth, the current account deficit is projected to rise to $9-9 \frac{1}{2}$ percent of GDP in 2008-09 - provided external financing remains available — due to strong public investment, high oil prices, and output constraints in the mining sector.

8. Potential output growth is being affected by the constraints in the electricity sector, but investment should restore growth potential down the road. Emergency rationing schemes will constrain potential output in the short term, implying that pressures on the current account and inflation will persist despite the slowdown in demand and output growth. An ambitious public infrastructure investment program seeks to address the bottlenecks in electricity, rail, and ports, and as infrastructure constraints are eventually relaxed, potential growth should rise towards an estimated 5 percent in the medium term.

\footnotetext{
${ }^{3}$ See accompanying Financial System Stability Assessment report.
} 


\begin{tabular}{|c|c|c|c|c|c|c|}
\hline \multicolumn{7}{|c|}{ Key Macroeconomic Variables } \\
\hline & 2008 & 2009 & 2010 & 2011 & 2012 & 2013 \\
\hline GDP growth, percent & 3.8 & 3.7 & 4.4 & 4.8 & 5.0 & 5.0 \\
\hline Inflation (CPIX, eop), percent & 11.6 & 8.1 & 5.9 & 4.5 & 4.5 & 4.5 \\
\hline Current account balance, percent of GDP & -9.0 & -9.6 & -9.5 & -9.3 & -9.1 & -8.9 \\
\hline \multicolumn{7}{|c|}{ Electricity Supply and Potential Output } \\
\hline Electricity supply growth rate, percent & 2.1 & 2.9 & 3.9 & 4.1 & 4.1 & 4.1 \\
\hline Improvement in average energy intensity, percent & 1.6 & 1.0 & 1.0 & 1.0 & 1.0 & 1.0 \\
\hline Potential GDP growth rate, percent & 3.7 & 3.9 & 5.0 & 5.0 & 5.0 & 5.0 \\
\hline Output gap, percent & 1.1 & 0.9 & 0.3 & 0.1 & 0.1 & 0.0 \\
\hline
\end{tabular}

9. Downside risks have increased significantly:

- the large current account deficit, which leaves South Africa vulnerable to a loss in investor confidence and a sudden stop in capital inflows (Box 2) that would result in an abrupt adjustment in domestic demand and a sharp depreciation of the exchange rate, implying renewed inflationary pressures and necessitating further interest rate increases;

- further increases in global food and fuel prices, which would put direct additional pressure on the current account deficit and inflation, and would also slow down the economies of partner countries; and

- and, on the domestic side, elevated debt service burdens among households, which pose risks to consumption growth and possibly to pockets of the financial system as interest rates remain high or are raised further.

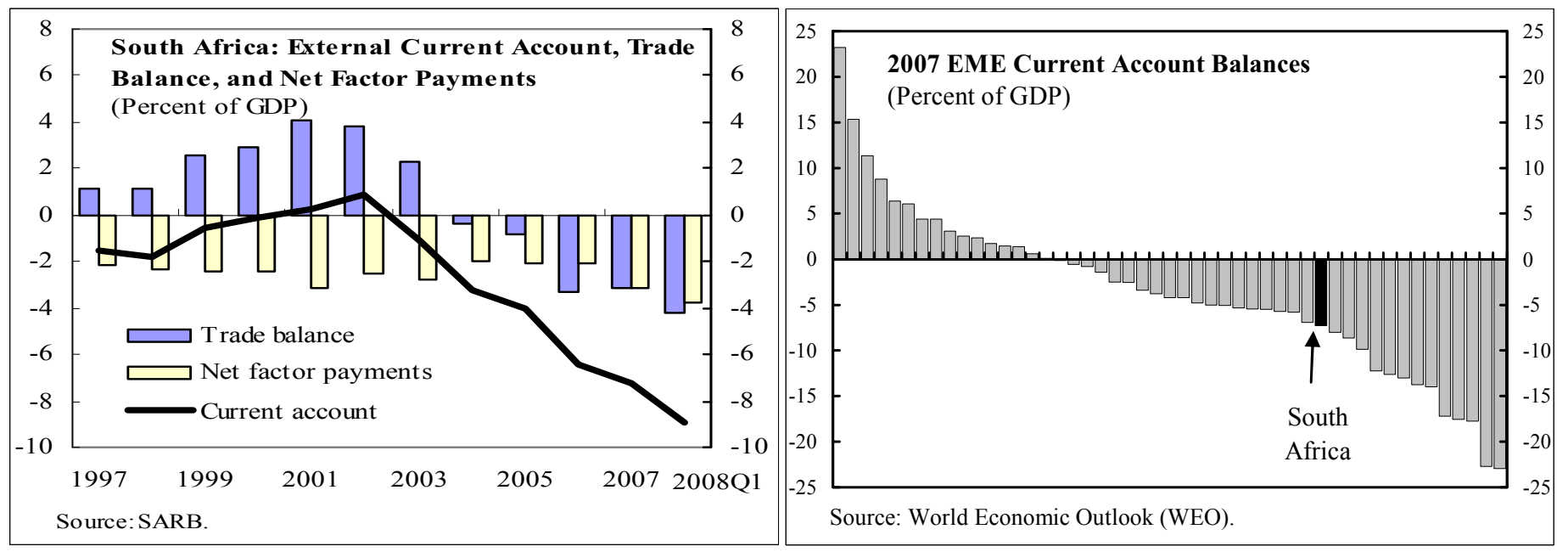




\section{Box 2. Current Account Vulnerabilities}

South Africa's current account deficit (CAD) is high relative to those of most EMEs and tends to be financed by potentially more volatile capital inflows. Compared with other EMEs, foreign direct investment (FDI) - which tends to be relatively stable - accounts for a smaller proportion of South Africa's CAD financing. Among countries with large CADs, South Africa remains an outlier in its heavy reliance on portfolio flows, reflecting its well-developed financial markets.
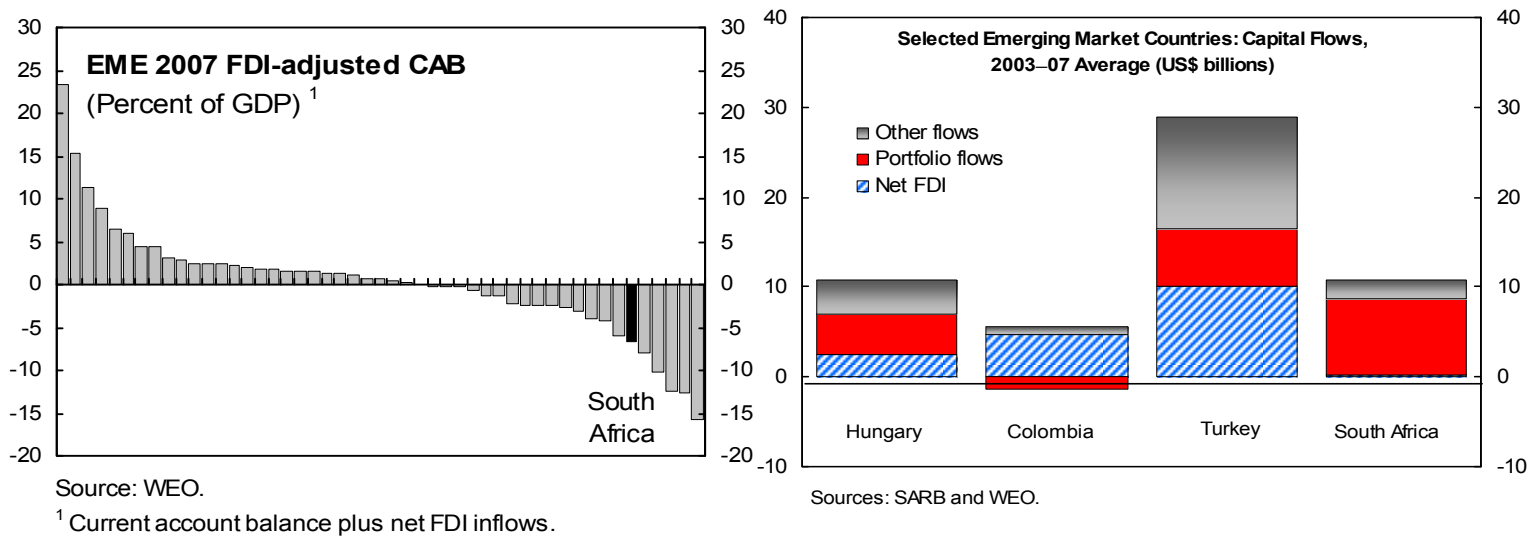

Capital inflows to South Africa have become more volatile lately. In late 2007 and early 2008, nonresidents' net purchases of South African equities and bonds shrank significantly and total portfolio flows turned negative. By end-March 2008, reflecting political uncertainty and power outages, South Africa's EMBIG spread widened more than those of other EMEs with large current account deficits, before receding somewhat by mid-year.

South Africa: CAD and Financing by Type of Identified Flows

Selected EMEs:

Change in EMBIG spreads vs. end-October 2007

\begin{tabular}{lrrr}
\hline & \multicolumn{3}{c}{ Basis point change as of } \\
\cline { 2 - 4 } & $1 / 31 / 2008$ & $3 / 31 / 2008$ & $6 / 30 / 2008$ \\
\hline South Africa & $\mathbf{1 1 1}$ & $\mathbf{1 5 7}$ & $\mathbf{1 1 8}$ \\
EMBIG & 79 & 112 & 98 \\
Colombia & 99 & 96 & 60 \\
Turkey & 66 & 140 & 176 \\
Hungary & 29 & 49 & 63 \\
\hline
\end{tabular}

Source: IMF, Global Markets Monitor.
(US\$ billions)

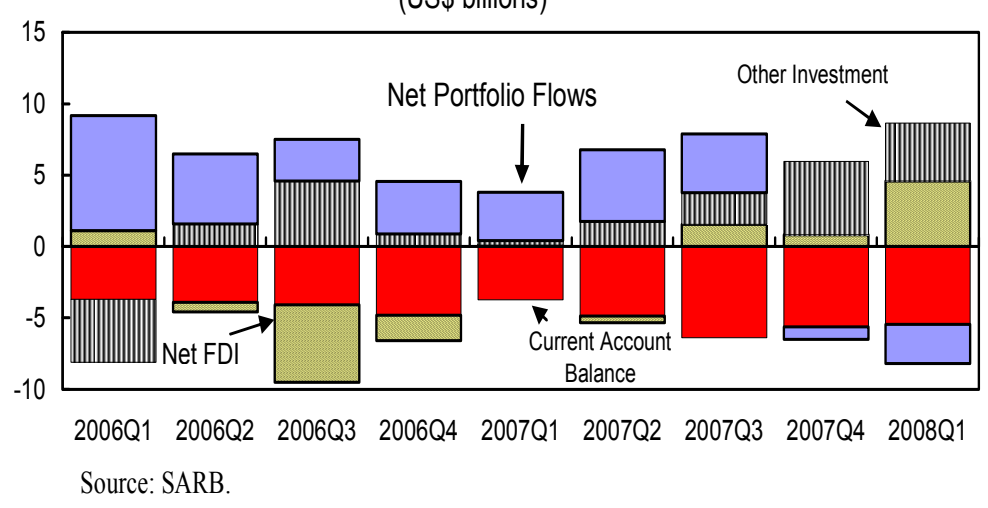

Financing of the current account deficit has become less reliable. In 2007Q4, widening interest rate differentials vis-à-vis mature markets appeared to have encouraged banks to repatriate foreign assets to the tune of US\$3.5 billion. In 2008Q1 a one-off deal- the purchase of a 20 percent stake in Standard Bank by ICBC, a major Chinese bank-led to a large net FDI inflow (US $\$ 4.5$ billion). In addition, nonresidents increased deposits with South African banks by some US $\$ 2.5$ billion, possibly reflecting a shift in the composition of inflows in response to higher interest rates. These flows could be volatile and thus not a reliable source of financing for the current account deficit in the longer run. 
10. The authorities broadly agreed with the staff's macroeconomic projections, the principal difference being their more optimistic outlook for the current account. They envisage a current account deficit in 2008-09 of 7-8 percent of GDP mainly reflecting lower oil price assumptions (by 19 percent on average in 2008-09) and lower projections for net factor payments abroad, compared with the staff's projection.

\section{The authorities concurred that risks have sharpened, particularly with regard} to the current account deficit, but underscored that the outlook remains positive on the whole, and the risks manageable. They stressed that the widening of the current account deficit reflects in part the ongoing investment drive to address infrastructure constraintswhich the staff agreed was essential for South Africa to maintain its growth momentum over the medium term. They were confident that nonresident investors would continue to fund the current account deficit, as they would recognize that these resources were being channeled to productive investments that would yield a globally competitive rate of return.

\section{The authorities also emphasized that South Africa's fundamentals prepare it to} weather possible shocks. The country still has a low level of external debt $\left(26 \frac{1}{2}\right.$ percent of GDP at end-2007), over 40 percent of which is denominated in rand. Gross reserves exceed short-term foreign currency debt by a comfortable margin. The banking sector is sound, and corporate and financial sector balance sheet exposures to exchange rate and interest rate shocks are limited, even if pockets of weakness exist among over-extended households. The authorities underscored their continued commitment to the current stability-oriented macroeconomic policy framework, which would bolster investor confidence. Should sentiment change anyway, foreign investors would share in the adjustment due to the flexible exchange regime and the high proportion of their investments held in rand, particularly in the form of equity.

\section{Staff agreed that South Africa's fundamentals remain strong, but emphasized} that the size and relatively rapid expansion of the current account deficit itself posed risks. Staff analysis suggests that South Africa's external and government debt is sustainable under a variety of shocks, remaining below 43 percent of GDP in stress tests (Appendix I). However, international experience shows that sharp adjustments in the current account have occurred even when external and public debt were at relatively moderate levels. Moreover, although the widening current account deficit reflected mainly the rise in investment, long-term solvency did not preclude the possibility of a liquidity crisis should investor sentiment turn negative.

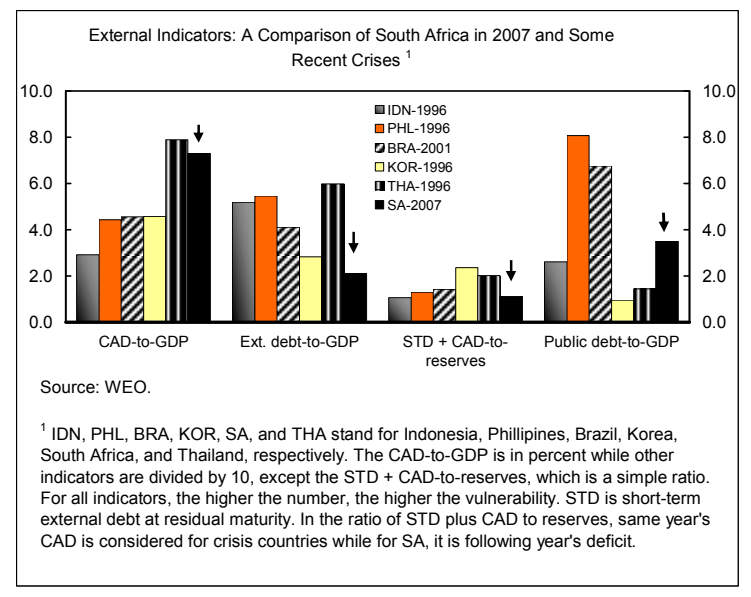




\section{Policy Discussions}

\section{Box 3. Summary of Previous Consultation Discussions}

There has been broad agreement on policies, as the Fund has generally supported the authorities' choices on fiscal policy, inflation targeting, exchange rate policies, international reserves accumulation, and exchange control liberalization. On structural policies, the Fund has supported South Africa's fiscal and financial sector reforms, and trade liberalization. It has encouraged identifying and revising aspects of labor legislation and institutions that constrain job creation. The Fund has also recommended further liberalization and simplification of the trade regime; the authorities have indicated that actions in this area depend on the outcome of multilateral negotiations.

\section{A. Containing Inflation Pressures}

\section{Monetary tightening to limit second-round effects}

\section{Like in other countries, inflation in South Africa has been rising strongly owing} in part to global shocks to fuel and food prices. The direct first-round effects from such shocks have been large since food represents a sizable fraction of the consumption basket and world oil price changes are fully and quickly passed through to domestic prices. ${ }^{4}$ Second-round effects from those shocks are in train as reflected, for example, by recent doubledigit wage settlements and the sharp increase in inflation expectations. The

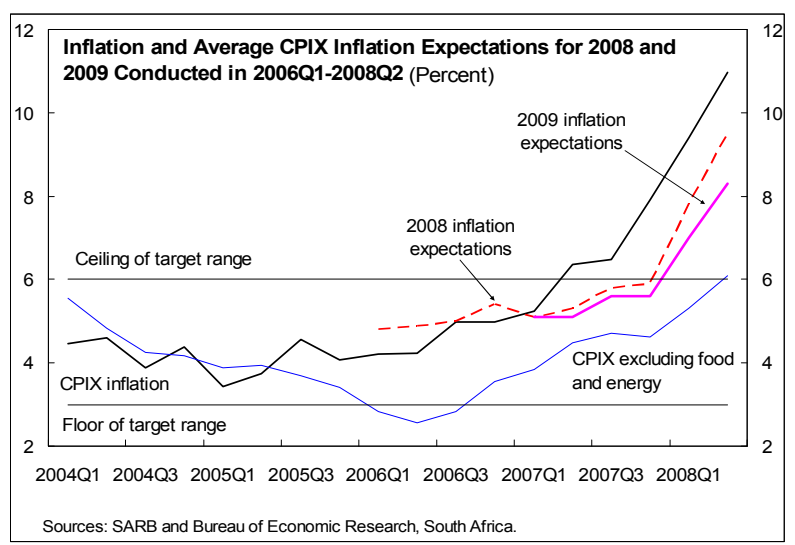
CPIX excluding food and energy has also broken through the top end of the inflation target range, although it is too early to say whether this is limited to the pass-through of higher energy input prices or includes second-round effects.

\section{SARB officials stressed the challenges of addressing the most recent wave of} global food and fuel price increases, which has caught South Africa late in a monetary tightening cycle launched initially to address domestic demand pressures. The SARB has raised its policy rate by a cumulative 300 basis points since June 2007, on top of the 200 basis point increase in 2006 (Figure 3). It has faced a sharp increase in inflation and inflation expectations since the beginning of this year, at a time when its tightening cycle would have been expected to end as activity slowed. The SARB has noted that it will tighten as needed to

\footnotetext{
${ }^{4}$ Food items account for 26 percent of the CPIX basket, and gasoline for about 5 percent. These weights will, however, decline to about 18 percent and 31/2 percent, respectively, from January 2009, based on weights from the 2005-06 household survey.
} 
anchor inflation expectations and contain the second-round effects of global price shocks. Even as it has continued to tighten its policy stance, the SARB has implicitly accepted a lengthening of the time horizon within which inflation is forecast to return to the target band. Officials explained that this reflected their preference for raising the policy rate at an even pace (usually 50 basis points) to avoid the risk of policy volatility, given the uncertainty surrounding the

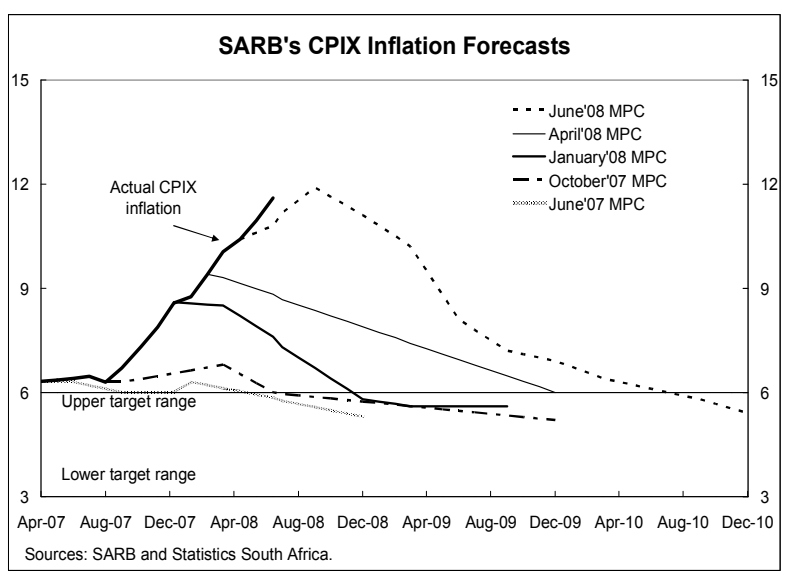
inflation forecast.

\section{Staff supported the tightening of monetary policy and suggested that further} rate increases are likely to be needed to bring inflation down. The SARB's actions are in line with those of many other central banks facing similar shocks and the professional consensus on the appropriate response. ${ }^{5}$ In staff's view, further tightening is likely to be needed for inflation to fall within the target band in a reasonable time period, provided supply shocks do not reverse and the output slowdown does not exert stronger-than-expected downward pressure on inflation. Staff also supported the effective lengthening of the monetary policy horizon given the large size of the shocks - the full effects of which are still working their way through the price system - and the unusual degree of uncertainty surrounding both their future path and the inflation forecast.

\section{High levels of household debt pose a risk of unintended side effects from} monetary policy tightening. The average household debt service ratio is approaching levels last seen in the second half of 1998, when an interest rate spike caused a noticeable deterioration in loan quality. Practically all household loans in South Africa carry a floating interest rate that tracks the policy rate closely. As the distribution of debt by household income is not reliably known, monetary tightening could have a larger-than-expected effect on household consumption and, eventually, the output gap. Given the strength of the financial system (see paragraphs 28-32), the risk is mainly macroeconomic, rather than systemic, in nature (Box 4). SARB officials noted that they keep a close watch on the average ratio of households' debt service to disposable income and felt that there was room for some additional tightening. Staff suggested that monetary policy deliberations ought to be informed by the collection and regular analysis of data on the distribution of household debt and debt service by income category since averages can mask tail risks. Assessments of financial system stability should also feed in to ensure - particularly at this stage of an extended tightening cycle - that cyclical and financial system effects of policy rate increases are assessed correctly.

\footnotetext{
${ }^{5}$ See Selected Issues paper, "Monetary Policy and Large Shocks to Relative Prices: Issues and Implications for South Africa."
} 


\section{Box 4. Risks from Rising Household Debt}

Mortgage nonperforming loan (NPL) ratios are rising, most likely as a result of the increase in interest rates. Rising mortgage rates seem to affect NPL ratios with a lag of 4-6 months. This impact could be accelerated and amplified by the slowdown in housing prices and real disposable income since late 2007.

The increase in mortgage NPL ratios has been steeper than in the previous cycle in 2002. Since the interest rate tightening cycle started in June 2006, mortgage debt repayments have expanded by some 36 percent. Each 100 basis points increase in mortgage rates has been associated with a rise in the mortgage NPL ratio of 0.5 percent — an impact four times larger than during the previous tightening cycle in 2002. This effect may be due in part to the much higher household indebtedness in June 2006 relative to the start of the previous tightening cycle. It could also indicate that a new class of borrowers - middle-income households - is being disproportionately affected by rising interest rates. Recent surveys (Credit Suisse Standard Securities, 2007 and 2008) show that most of the expansion in debt has occurred among the middle class, while higher-income households' debt exposure has remained constant or even declined. Still, the risk of large-scale foreclosures appears limited, as the "originate and hold" mortgage model prevails and banks tend to engage in debt workouts with troubled borrowers.

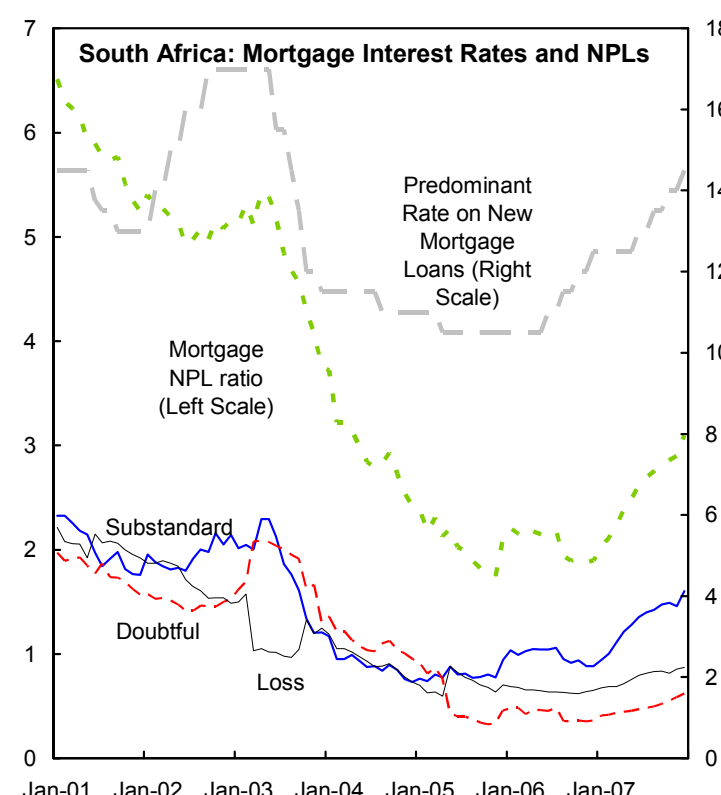

Jan-01 Jan-02 Jan-03 Jan-04 Jan-05 Jan-06 Jan-07

Source: SARB

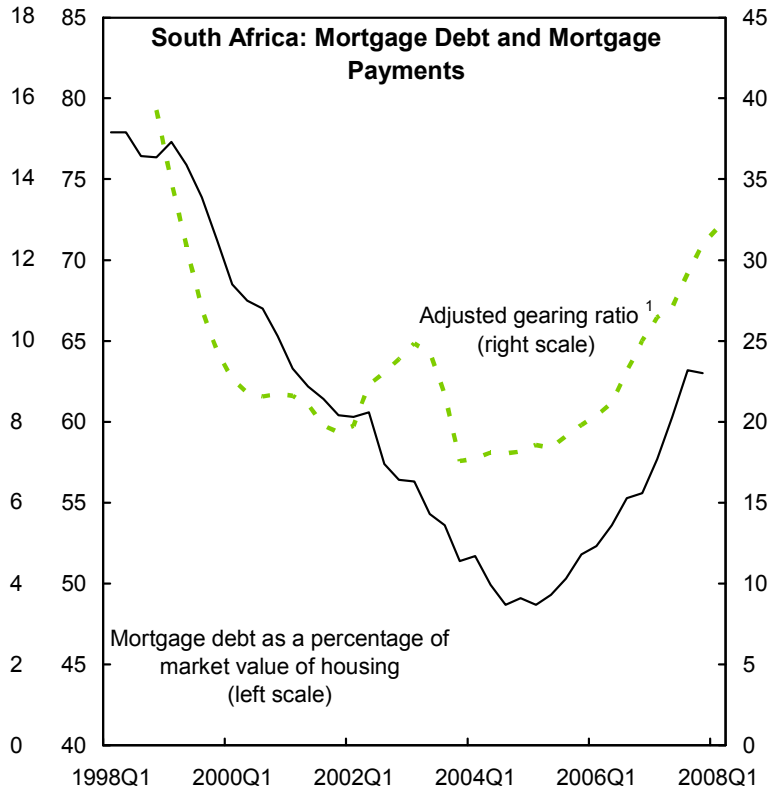

Source: SARB

${ }^{1}$ Debt serice as a percentage of disposable income of households with mortgages.

The banking system appears to be resilient to a deterioration in asset quality. FSAP Update stress tests suggest that banks could easily withstand a variety of large shocks. Specifically, basic stress tests assuming a default of all counterparties with a probability of default greater than 10 percent indicate that the impact would be limited to below $33 / 4$ percentage points of bank capital for each large bank. 


\section{Clear communications to contain inflation expectations}

18. Staff noted that the ongoing supply shocks and rising inflation expectations heighten the importance of clear communication, a key part of the inflation targeting regime. The quality of the SARB's written communications is high, with analysis of economic risks and rationale for policy decisions clearly laid out. At the same time, to help contain the rise in inflation expectations and discourage backward-looking wage indexation, additional efforts could be made — both by the SARB and the government - to educate the public about the nature of the current shocks and the absence of a long-run tradeoff between inflation and growth. As also noted by some market analysts, the SARB could also improve communication at the margin, for instance, by having the inflation fan chart reflect the Monetary Policy Committee's (MPC's) assessment of the inflation outlook and risks and publishing it and the quantitative outlook each time the MPC's decision is announced. It may also be useful to explore the possibility of communicating in broad terms the MPC's future policy intentions in the statement issued after MPC meetings, as is the practice among some inflation targeting central banks.

19. The authorities agreed on the importance of a careful communications strategy. Their efforts have been geared at explaining their actions to the public, both through their publications and through public fora held all over the country on a semi-annual basis. They have set out to explain the global nature of recent shocks and to offer context by discussing the actions of other central banks around the world. The authorities also felt that they convey sufficient information on their outlook for inflation, and that attempting to provide additional or more structured signals of their possible future actions to diverse audiences would be risky, as such signals would be easy to misinterpret as commitments.

\section{B. Addressing Vulnerabilities}

\section{Tighter fiscal policy to avoid exacerbating current account pressures}

20. South Africa's large current account deficit reflects a somewhat overvalued exchange rate (see paragraph 26) and a rising rate of investment that is funded by foreign saving. External stability therefore depends closely on maintaining foreign investors' confidence in South Africa's continued stable macroeconomic policies and good growth prospects. The inflation targeting framework, including the operational independence of the SARB, and prudent fiscal policy are both critical to investor perceptions of stable macroeconomic policies.

21. The steady strengthening of the public finances has been a positive factor in maintaining investor confidence even as the current account deficit has widened (Figure 4). For the second year running, the national government posted a fiscal surplus in $2007 / 2008$. Revenue was boosted beyond budgeted levels by strong income growth and commodity prices, as well as improved efficiency in tax collection. On the expenditure side, 
an increase in social spending and transfers to municipalities and public corporations more than offset a decline in interest payments. The public sector borrowing requirement (PSBR) was broadly balanced, which allowed public sector debt to decline to 35.4 percent of GDP by end-2007.

\section{The authorities indicated their} intention-which the staff supported-to maintain a broadly neutral stance in FY 2008/9 as envisaged in the budget. In nominal terms, revenue is projected to be higher than originally budgeted given higher-than-expected inflation this year.

\begin{tabular}{|c|c|c|c|}
\hline \multicolumn{4}{|c|}{ National Government Main Budget $^{1}$} \\
\hline & $2005 / 06$ & $2006 / 07$ & $2007 / 08$ \\
\hline & \multicolumn{3}{|c|}{ (Percent of GDP) } \\
\hline $\begin{array}{l}\text { Total revenue and grants } \\
\text { of which: }\end{array}$ & 26.0 & 26.6 & 27.3 \\
\hline Tax revenue & 25.4 & 26.0 & 26.7 \\
\hline Income tax & 14.5 & 15.5 & 16.1 \\
\hline Indirect taxes & 9.5 & 9.7 & 9.5 \\
\hline Trade and other & 1.3 & 0.9 & 1.0 \\
\hline $\begin{array}{l}\text { Total expenditure } \\
\text { of which: }\end{array}$ & 26.3 & 26.0 & 26.3 \\
\hline Interest expenditure & 3.2 & 2.9 & 2.6 \\
\hline Social expenditure ${ }^{2}$ & 14.4 & 14.6 & 14.9 \\
\hline Budget Balance & -0.3 & 0.6 & 0.9 \\
\hline \multicolumn{4}{|l|}{ Memorandum items: } \\
\hline Public sector borrowing requirement & -0.7 & -0.3 & -0.3 \\
\hline National government debt & 33.3 & 30.5 & 27.9 \\
\hline Domestic & 29.1 & 26.0 & 23.2 \\
\hline Foreign & 4.2 & 4.6 & 4.7 \\
\hline \multicolumn{3}{|c|}{ Sources: South African authorities and IMF staff estimates. } & \\
\hline
\end{tabular}
Together with likely underspending in certain areas, this would provide room for some additional targeted social expenditure in response to high food prices, despite higher-thanbudgeted wage expenditure reflecting the recent 10.5 percent public sector wage increase.

\begin{tabular}{|c|c|c|c|c|c|c|}
\hline \multicolumn{7}{|c|}{ Main fiscal balances, 2005/6 - 2010/11, percent of GDP } \\
\hline & $2005 / 06$ & $2006 / 07$ & $2007 / 08$ & $2008 / 09$ & $2009 / 10$ & $2010 / 11$ \\
\hline \multicolumn{7}{|l|}{ National government: } \\
\hline Overall balance ${ }^{1}$ & -0.3 & 0.6 & 0.9 & 0.3 & -0.3 & 0.4 \\
\hline Primary balance ${ }^{1}$ & 2.9 & 3.5 & 3.5 & 2.5 & 1.7 & 2.2 \\
\hline Cyclically adjusted primary balance ${ }^{2}$ & 3.1 & 3.2 & 3.0 & 2.4 & 1.7 & 2.0 \\
\hline Cyclically adjusted overall balance ${ }^{2,3}$ & -0.1 & 0.3 & 0.5 & 0.3 & -0.3 & 0.3 \\
\hline Extrabudgetary funds and institutions & 0.8 & 0.5 & 0.5 & 0.3 & 0.4 & 0.4 \\
\hline Provincial and local governments & -0.5 & -0.4 & -0.4 & -0.5 & -0.4 & -0.3 \\
\hline Nonfinancial public enterprises & 0.8 & -0.5 & -0.7 & -1.6 & -1.7 & -1.9 \\
\hline Cyclically adjusted public sector borrowing requirement & -1.0 & 0.0 & 0.2 & 1.5 & 2.1 & 1.5 \\
\hline \multicolumn{7}{|c|}{$\begin{array}{l}\text { Sources: National Treasury and IMF staff estimates. } \\
{ }^{1} \text { According to staff's fiscal and GDP projections. } \\
2 \text { IMF staff's cyclical adjustments using tax-specific elasticities to tax-specific base gaps (see IMF Country Report 06/328). } \\
{ }^{3} \text { Cyclically adjusted primary balance less interest expenditure. }\end{array}$} \\
\hline
\end{tabular}

23. In view of the risks from the large current account deficit, the already high burden on monetary policy, and plans to raise public investment significantly, staff suggested that government saving could be increased gradually to bring the structural PSBR to zero over the medium term. With existing government and public enterprise investment plans treated as a given, this would imply increasing the government's cyclicallyadjusted overall balance by $1 \frac{1 / 2}{2}-2$ percentage points of GDP over the next three years starting in FY2009/10. Such an increase in government saving would help assure markets and foreign investors that the government is taking firm action to ensure that the public sector does not add to the rising external imbalance. As the offsetting decline in private saving for a given increase in public saving tends to be greater for tax increases than for expenditure cuts, the 
fiscal strengthening would be more effective if achieved by containing the growth in current spending.

24. While agreeing that the current account deficit posed risks, the authorities indicated that there was little leeway to increase government saving given the rising demand for public services. South Africa's comparatively weak outcomes in education and health, and high crime rate limited the scope for containing current spending. With little prospect of raising national saving, they had no choice but to rely on foreign saving to fund the higher public investment needed to relieve the constraint on growth from electricity and other infrastructure bottlenecks. That said, the authorities stressed their commitment to a prudent budget policy and their expectation that these policies would continue after the political transition next year as well. The authorities also noted that they had taken advantage of the strong growth over the last several years to reduce government and public debt to moderate levels, and hence a modest widening of the PSBR to fund investment needs posed limited risks. Staff recognized the constraints faced by the authorities, but felt there was some scope for increasing saving by seeking better value for money and placing more emphasis on policy reform, rather than additional spending - especially since spending in areas such as education was not low by international comparison (see paragraph 36).

\section{External policies geared to cushioning shocks}

25. South Africa maintains a flexible exchange rate system. The rand is a relatively volatile currency - partly reflecting the relatively high proportion of off-shore trading. Officials noted that, in line with its published policy, the SARB purchases foreign exchange in the market to build up gradually its reserve position, without seeking to influence the value of the exchange rate. They emphasized their commitment to a freely floating exchange rate, and indicated that the rand would be allowed to depreciate in the event of capital outflows, as in early 2008. Staff agreed that the exchange rate should be allowed to adjust flexibly, including in the event of an adverse shock.

26. The Fund's methodology for assessing the level of the exchange rate suggests that the rand may be moderately overvalued, although considerable uncertainty surrounds this estimate. Staff's assessment, based on two methodologies, suggests that the rand's overvaluation was about 13-16 percent in mid-2008, reflecting the projected large current account deficits (Box 5). However, a third methodology suggests undervaluation of about 12 percent, indicating the range of uncertainty surrounding the estimates. The authorities view the exchange rate as the outcome of market forces and in line with fundamentals. They dismissed as counterproductive - and the staff agreed — calls from some quarters to try to influence the level of the real exchange rate through intervention. 


\section{Box 5. The Real Exchange Rate and Competitiveness}

Staff's assessment of South Africa's exchange rate is based on the IMF's CGER methodology, using data as of mid-2008. ${ }^{1}$ Two of the methods - the macroeconomic balance approach and the external sustainability approach, which compare the medium-term current account deficit to a "norm" derived from cross-country analysis - yielded an overvaluation of about 13 and 16 percent, respectively, reflecting the substantial projected current account deficits, even after adjusting for the temporary rise in public investment. ${ }^{2}$ Under the third method - the equilibrium REER approach (a single-equation method relating the real effective exchange rate to its fundamental determinants) - the rand appeared undervalued by 12 percent, mainly reflecting high commodity export prices.

South Africa's export performance has been somewhat lackluster. In value terms, South Africa's market share has been rising gently since 2002, in line with the upward trend in world commodity prices. In real terms, however, market share has been on a declining trend reflecting in part the falling volume of gold exports. Export performance has varied across the four largest destinations.

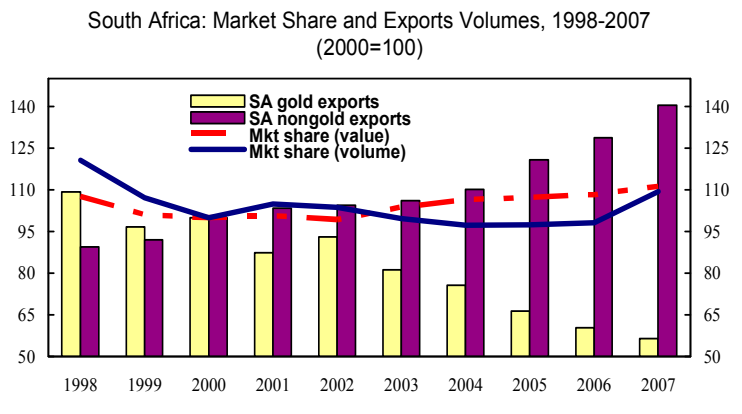

Source: IMF, Direction of Trade and WEO.

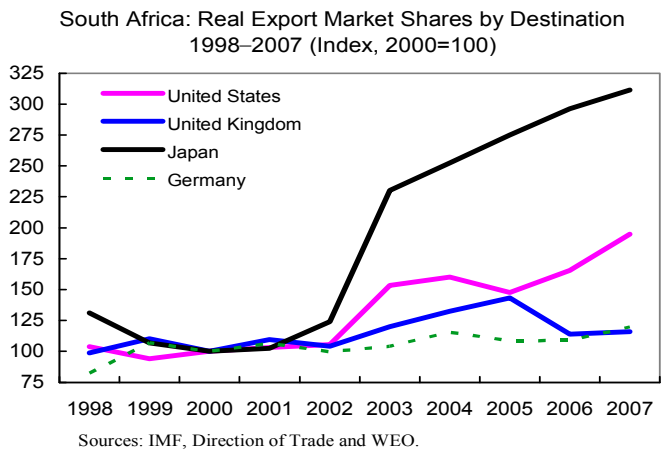

Sources: IMF, Direction of Trade and WEO

Survey-based evidence suggests that South Africa has room for improving competitiveness in some areas. It scores relatively weakly on economic performance (reflecting its large current account deficit and high unemployment) and infrastructure, and comparatively well on government efficiency. Overall, among selected EMEs, South Africa ranks close to Brazil and Mexico, but not as high as Chile and the more dynamic Asian economies.

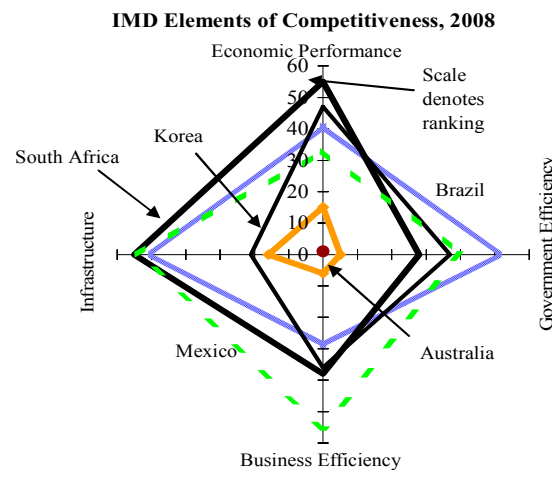

Source: IMD World Competitiveness Yearbook (2008)

\begin{tabular}{lrrrr}
\multicolumn{4}{c}{ World Competitiveness Ranking $^{1}$} \\
\cline { 2 - 5 } & \multicolumn{3}{c}{ WEF } & \multicolumn{3}{c}{ IMD } \\
\cline { 2 - 5 } & 2006 & 2007 & 2007 & 2008 \\
\hline Australia & 18 & 19 & 12 & 7 \\
Brazil & 66 & 66 & 49 & 43 \\
Chile & 27 & 26 & 26 & 26 \\
China & 54 & 34 & 15 & 17 \\
India & 43 & 48 & 27 & 29 \\
Korea & 24 & 11 & 29 & 31 \\
Mexico & 58 & 52 & 47 & 50 \\
South Africa & 45 & 44 & 50 & 53 \\
Memorandum items & & & & \\
$\quad$ Number of countries ranked & 125 & 131 & 55 & 55 \\
$\quad$ South Africa's rank on infrastructure & 49 & 43 & 55 & 55 \\
\hline
\end{tabular}

Sources: World Economic Forum (WEF) and International Institute for Management Development (IMD).

The years mentioned refer to the timing of the surveys.

${ }^{1}$ The methodology uses three approaches, which the staff has adapted to South Africa's circumstances. Using comparisons with other EMEs, staff estimates South Africa's current account norm at about 3.3-4.1 percent of GDP, although estimates are sensitive to assumptions (see IMF Country Report 07/274). The medium-term (2013) current account deficit, stripped of temporary factors, is projected at 7.2 percent of GDP.

${ }^{2}$ Temporary factors should be excluded from the assessment of the equilibrium exchange rate. Including the surge in public investment, the estimated overvaluation would rise to 20 and 24 percent, respectively. 
27. The authorities indicated that they intend to continue strengthening gradually their gross international reserves, which rose to US\$34.9 billion at end-June 2008. They noted that reserves were still insufficient to cover the sum of the current account deficit and short-term debt and were also low compared with levels in other EMEs. As in the past, they noted that they did not have a specific timetable, nor a particular target level of reserves in mind. Staff agreed with this approach, observing that a larger reserve cushion would mitigate the risks from the widening current account.

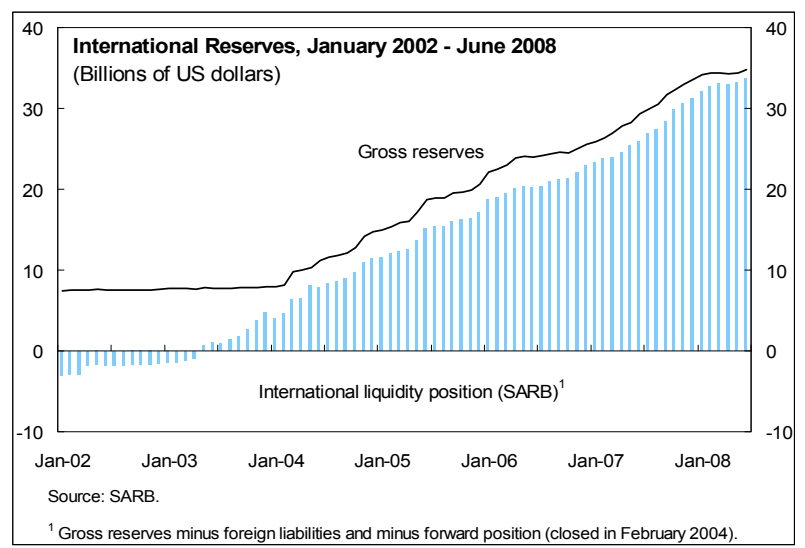

South Africa: Indicators of Reserve Adequacy at end-2007

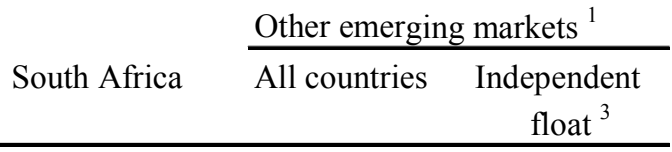

Ratio of international reserves to:

(In percent, unless otherwise indicated)

Short-term debt ${ }^{2}$

177.6

140.9

141.1

Short-term debt plus current account deficit ${ }^{2}$

70.9

89.7

111.8

GDP

11.7

17.4

Imports of goods and services (in months)

3.2

4.1

3.5

Broad money

14.0

31.3

28.9

Source: South African authorities and IMF staff estimates.

${ }^{1}$ Median values for a group of almost 48 emerging market countries.

${ }^{2}$ Short-term debt at remaining maturity.

${ }^{3}$ Countries with independently floating exchange rate regime as defined by the IMF Annual Report on Exchange Arrangements and Exchange Restrictions (2007).

\section{Enhancing the resilience of the financial system}

28. A robust financial system is critical for maintaining macroeconomic stability and increasing the economy's resilience to shocks. The FSAP Update found that South Africa's financial system is sound, underpinned by a well-established legal and financial infrastructure and a generally effective regulatory framework. Financial institutions have enjoyed good profitability, capitalization levels and reserves, and the system so far has weathered the global financial market turmoil without major pressures. The implementation 
of Basel II at the start of 2008 has proceeded smoothly and is largely capital-neutral for the largest banks.

29. Financial institutions are now, however, facing a less benign environment and are beginning to see the effects of slowing economic activity and rising interest rates on asset quality and returns. With households' indebtedness at record levels and their debt service burden rising, the banking system is facing elevated credit risk in its household loan portfolio. Also, the concentration of banks' deposits on relatively few large corporations makes their balance sheets sensitive to changes in sentiment about the relative strength of individual banks. In such an environment, staff recommended that the SARB should continue its forward-looking proactive engagement with banks and use the scope available under Basel II to ensure that capital buffers in banks are adequate to cope with increasing risks. In addition, it would be important to closely monitor emerging risks through robust financial stability analysis, particularly regular offsite integrated top-down and bottom-up stress testing, including of adverse macroeconomic scenarios. Such tests of systemic stability based on individual bank data would allow the identification of tail risks that may not be evident in aggregate top down exercises. Staff also recommended that bank liquidity and funding risks should also be monitored closely.

30. Staff welcomed the strengthening of the framework for contingency planning and emergency liquidity assistance as a bulwark for mitigating the fallout, should an adverse event occur. The Financial Sector Contingency Forum aims to facilitate interagency coordination and preparedness for addressing crises. Staff suggested that the arrangements should be periodically tested and the authorities should consider undertaking a crisis simulation exercise relating to a macrofinancial shock such as a capital outflow or distress in a large financial sector institution.

31. The FSAP Update also found that South Africa's regulatory framework for the financial sector is modern and generally effective and suggested some areas for further strengthening, including:

- Consolidated supervision of financial conglomerates. This should be possible within existing organizational arrangements by combining strong sectoral supervision with a focus on risks that cut across intermediaries within a financial group. Coordination among regulators and policy makers could be strengthened, with gaps and overlaps minimized, and respective responsibilities clearly delineated;

- $\quad$ Risk management, corporate governance, internal controls in the nonbank sector. Continue efforts by the Financial Services Board to develop standards for corporate governance, risk management, and internal controls and harmonize its risk-based models for different sectors. Further measures are also needed to encourage the consolidation of pension funds and to strengthen their governance and risk management;

- $\quad$ Furthering the reach of financial services. Fostering greater competition and innovation in developing affordable, flexible, and appropriate financial products for the low- 
income market. This will require a regulatory environment that provides space for innovation while maintaining financial stability.

\section{The authorities broadly agreed with the findings and recommendations of the}

FSAP Update. They indicated that they would continue to enhance their risk analysis, including by exploring ways to conduct systemic stress testing while protecting the confidentiality of individual bank data. Staff encouraged the authorities to explore mechanisms used by other countries to overcome this hurdle. The authorities noted that their crisis management systems had been tested to some extent by several actual (nonsystemic) crises, but agreed to consider a simulation of the sort suggested by staff, provided they could ensure that the simulation itself does not become a source of risk. The authorities indicated that they were exploring possibilities for consolidating supervision of financial conglomerates, for instance, by establishing supervisory "colleges" (comprising supervisors from different agencies) for each conglomerate. The authorities also indicated that they would consider the various detailed recommendations of the FSAP Update, including those pertaining to insurance, pensions, and securities markets. They planned to convene an interagency forum to discuss the detailed findings and to develop proposals for addressing them.

\section{Fostering Shared Growth}

33. The authorities' medium-term growth strategy (ASGISA) aims to raise growth from $4 \frac{1}{2}$ percent in 200509 to 6 percent in $2010-14$ by addressing six key constraints on growth: (i) inadequate infrastructure and logistics; (ii) skills shortages; (iii) barriers to entry and competition in several key economic sectors; (iv) the regulatory environment; (v) capacity limitations within the government; and (vi) the volatility of the exchange rate. ${ }^{6}$ However, structural reforms to address these constraints have lagged, in part because of the complexities of addressing problems inherited from the apartheid era and resistance by vested interests.

Increasing investment by raising national saving

34. Staff's work suggests that the main constraint on growth has been South Africa's comparatively low investment and saving rates and, to a lesser extent,



\footnotetext{
${ }^{6}$ Previous staff analysis found that while exchange rate volatility could pose certain problems, mostly related to long-term investment, the overall evidence on its harmful effects was inconclusive (see IMF Country Report $06 / 328)$.
} 
lower total factor productivity growth. ${ }^{7}$ While a number of factors have affected investment, low national saving seems to be the most important one. South Africa's national saving rate has fallen sharply since the mid-1980s and is now low compared with that of other EMEs. While the household saving rate is very low, it is mainly the decline in corporate saving (which comprised 97 percent of nongovernment saving in 1997-2007) that has driven the national ratio downward. Closer analysis suggests that private saving has evolved in line with the structural (e.g., urbanization, demographics) and economic fundamentals of the economy, which would be difficult to reverse. Higher public saving appears to be the main option available to raise national savings over the medium term, even with a partial offset from the private sector. To the extent that it is politically infeasible to increase public saving by an adequately large amount, staff argued that more emphasis would need to be placed on (i) modifying government revenue and expenditure policies to support growth and employment; and (ii) implementing structural reforms to boost total factor productivity growth.
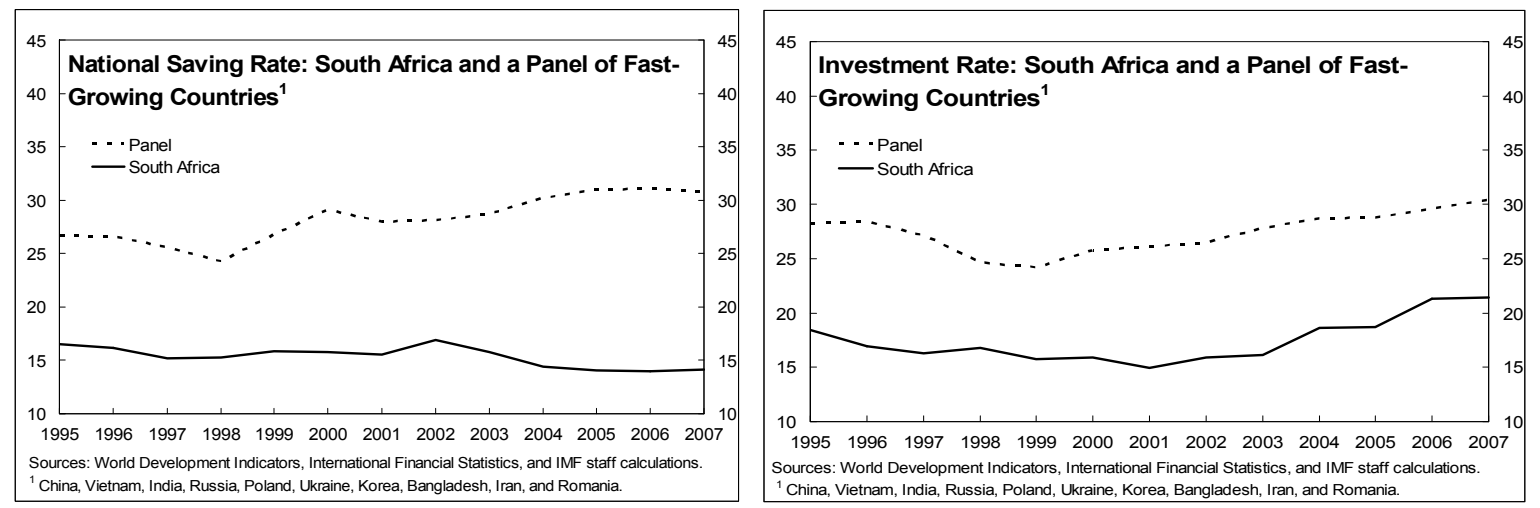

35. Growth and employment could be strengthened by continuing to rebalance the government's revenue-expenditure policies within a given overall fiscal stance. For instance, combining the increase in public infrastructure investment with cuts in the corporate income tax could boost growth. ${ }^{8}$ Cuts in the personal income tax-aimed at benefiting the middle income range of skilled workers and small business — or a wage subsidy could raise employment, although the gains may be modest. Such a package could be financed by the planned introduction of mining royalties - capturing some of the economic rents provided by high mineral prices - environment-friendly levies, or property taxes, and slower growth in government consumption than currently planned. Adverse distribution consequences could be addressed by appropriate adjustments in the transfer system. In a similar vein, staff noted that it will be important over the medium term to make sure that the

\footnotetext{
${ }^{7}$ See Selected Issues paper, “Constraints on Growth in South Africa: Lessons from a Cross-country Comparison."

${ }^{8}$ See Selected Issues paper. "Can Fiscal Policy Boost Growth and Employment in South Africa?”
} 
planned social security reform is designed to avoid negative effects on labor costs, competitiveness, the fiscal balance, and national saving.

36. Structural reforms, particularly in labor and product markets, are critical for improving total factor productivity and employment growth. The ASGISA framework has already identified limited competition, skill shortages, and implementation capacity within government among the factors constraining growth. While efforts are being made to address these issues, much remains to be done. Staff suggested that:

- $\quad$ opening up the economy to greater international competition is critical for efficiency. The overall level of protection could be further reduced and the MFN import tariff structure simplified, including by reducing the number of tariff bands and lines;

- $\quad$ lowering administrative and regulatory burdens in product and labor markets could also help foster labor-intensive growth in tradables; ${ }^{9}$

- $\quad$ involving the private sector in public service provision could improve efficiency, including through greater competition in electricity generation and distribution, port services, and rail transport; ${ }^{10}$ and

- improving educational attainment is important for ensuring labor productivity gains in the long term. Since South Africa already spends comparatively generously on education, efforts need to focus on improving results within the existing budget envelope and raising student achievement towards international standards.

\section{The authorities agreed that growth would benefit from further structural} reforms, but had different views on the potential for reform in certain areas. They were skeptical of the growth dividend from additional cuts in the corporate tax rate. While they agreed that further opening the economy to external competition would increase efficiency, their preference was to take decisions in this area in the context of multilateral negotiations. They pointed to efforts to identify interventions to raise the productivity of education

\footnotetext{
${ }^{9}$ A recent OECD report links weak product market competition and low labor utilization in South Africa, noting that the former has enabled "large incumbent firms to set high prices and make excess returns, which in turn makes possible for them to pay wages above...the market clearing wage rate". The report stresses the complementarities between measures to strengthen product market competition and policies to facilitate mobility in labor markets, which would permit more job-rich, equitable growth. OECD, Economic Assessment of South Africa, July 2008, pp. 5-6.

${ }^{10}$ The OECD report also finds that "the overall burden of regulation is relatively heavy by OECD standards and ...state ownership and interference impose high barriers to entry in many areas. In particular, the lack of competition and uncertain decision-making processes in network industries impede their efficient development in terms of productivity and innovation, with negative spillover effects for the whole economy." OECD, Economic Assessment of South Africa, July 2008, Summary, p.2.
} 
spending — which they considered unsatisfactory — but noted that improvements in quality may require additional public spending.

\section{Regional Integration}

38. South Africa attaches high importance to efforts to promote regional economic integration within the framework of the Southern African Development Community (SADC). SADC is scheduled to initiate a free trade agreement (FTA) at its annual summit meeting in mid-August, although not all fourteen members of SADC will participate. The FTA was to be a stepping stone towards implementing a SADC customs union in 2010, but South African officials noted that this timetable was no longer achievable. In their view, a realistic plan for a regional customs union would likely have to be based on some form of gradual expansion of the existing Southern Africa Customs Union (SACU).

39. Seven SADC countries have been negotiating an Economic Partnership Agreement (EPA) with the European Union. Four of the five members of SACU (Botswana, Namibia, Lesotho, and Swaziland), along with Mozambique, initialed an Interim EPA with the EU in late 2007, and discussions on elements of a full EPA with the EU are ongoing. South Africa did not sign the Interim EPA, but is continuing negotiations with the EU on trade and market access issues.

\section{Staff APPRAisal}

40. South Africa has made significant economic strides over the past several years. Output and income have expanded steadily, while inflation has remained moderate until recently. Strong employment growth has reduced unemployment despite a sustained increase in labor force participation. These achievements can be attributed in no small measure to sound macroeconomic policies, implemented in the context of a transparent policy framework, which have provided a stable environment for private sector activity.

41. The short-term outlook has deteriorated and downside risks have increased significantly. Growth is expected to be constrained for some time until the infrastructure investment program bears fruit, while inflation stays elevated due to global price shocks and the external current account deficit remains high, underscoring the dependence on potentially volatile capital inflows. The main risks stem from a possible loss in investor confidence and sudden stop in capital inflows; a possible further deterioration in the global economic environment, especially a significant increase in the world oil price; and high levels of household indebtedness, particularly as interest rates are raised to combat inflation and income growth slows. The impact of any shocks would be mitigated to some extent by South Africa's strong fundamentals, which include a sound macroeconomic policy framework, a low level of short-term external debt, and strong financial system balance sheets.

42. The SARB's tightening of monetary policy and effective lengthening of the policy horizon have been appropriate responses to the successive supply shocks from 
food and energy prices. Further monetary policy tightening may be needed to anchor inflation expectations and contain second-round effects, if supply shocks do not reverse and the downward pressure on inflation from slowing activity does not turn out to be larger than expected. It will be important, in this context, to monitor closely the impact of high interest rates on overextended households. Clear and consistent communications to the markets and public will also be important in influencing inflation expectations and containing secondround effects.

43. Fiscal policy could be geared to addressing vulnerabilities by not adding to the rising external imbalance and bolstering investor confidence. Given plans to raise public investment, government saving could be increased starting next fiscal year to reduce the structural public sector borrowing requirement to zero over the next three years. Maintaining a broadly unchanged cyclically-adjusted overall government balance this year would help safeguard macroeconomic stability by allowing the full play of automatic stabilizers in response to cyclical conditions. Beyond that, taking public sector investment plans as a given, the PSBR could be reduced to zero by increasing the cyclically-adjusted general government balance by $1 \frac{1}{2}-2$ percent of GDP over the next three years. Containing current expenditure, rather than raising taxes, may be more effective as offsetting behavior by the private sector is likely to be less pronounced for spending than for taxes.

\section{South Africa's floating exchange rate regime provides an important buffer} against external risks. The flexibility of the rand has contributed to limiting foreign exchange exposure in corporate and financial sector balance sheets and discourages speculative inflows when interest rate differentials vis-à-vis the rest of the world widen. Moreover, in the event of a sudden stop in capital inflows, the flexible rate implies that foreign investors would share in the adjustment burden. The exchange rate appears moderately overvalued, but is driven by private sector behavior rather than public policies.

\section{The government's policy of gradually building up international reserves} remains appropriate. An adequate reserve cover is also an important cushion against current account vulnerabilities. Although reserves are comfortable in relation to short-term debt, they are less so when measured against other indicators.

\section{The FSAP Update found that South Africa's sophisticated financial system is} broadly sound, well capitalized, and well regulated, but now faces a less benign environment as activity slows and interest rates rise. In this context, the SARB should continue its forward-looking proactive engagement with banks and use the scope available under Basel II to ensure that capital buffers in banks are adequate to cope with increasing risks. In addition, it would be important to closely monitor emerging risks, particularly related to high levels of household debt, through integrated, forward-looking financial stability analysis based on bank-level data. The strengthening of the framework for financial contingency planning and emergency liquidity assistance is welcome and periodic testing, including through crisis simulations, may be useful. The regulatory framework could be 
further strengthened by consolidating the supervision of financial conglomerates; continuing efforts to strengthen insurance and pension supervision; and fostering greater competition and innovation in meeting the needs of the low-income market.

47. The pressing need to accelerate growth and employment over the medium term is clear, the question is how to do this without jeopardizing macroeconomic and financial stability. South Africa's low national saving rate is a constraint on raising investment on a sustained basis to levels seen in comparable emerging market countries. Raising public savings should be the first step in boosting national savings. If the scope for raising public saving, and hence investment, is limited, more emphasis needs to be placed on other policies to boost productivity and employment growth. Modifying government revenue and expenditure policies within a given overall fiscal stance to strengthen incentives to invest and work is an option. Possibilities could be explored - for instance, further cuts in corporate taxes or well-targeted wage subsidies financed by the planned introduction of mining royalties or property taxes, or a slowdown in government consumption.

48. Structural reforms, particularly in labor and product markets are also critical for improving productivity and employment growth. More focus could be given to:

(i) opening up the economy to greater international competition by reducing and simplifying tariffs; (ii) strengthening product and labor market competition by lowering administrative and regulatory burdens; (iii) improving efficiency in public service provision by greater private sector involvement, particularly in electricity generation and distribution, port and rail transport; and (iv) reforms to improve education outcomes for given public spending.

49. It is expected that the next Article IV consultation will be held on the standard 12-month cycle. 
Table 1. South Africa: Selected Economic and Financial Indicators, 2003-09

Nominal GDP (2007): US\$282.6 billion

Population (2007): 47.9 million

GDP per capita (2007): US\$ 5,907

\begin{tabular}{lllllll}
2003 & 2004 & 2005 & 2006 & 2007 & 2008 & 2009 \\
\hline
\end{tabular}

\section{National income and prices}

Real GDP

Real GDP per capita

Real domestic demand

GDP deflator

$\mathrm{CPI}$ (annual average)

CPIX (end of period) ${ }^{1}$

\section{Labor market}

Unemployment rate (percent)

Average remuneration (formal nonagricultural sector)

Labor productivity (formal nonagricultural sector)

Nominal unit labor costs (formal nonagricultural sector)

\section{External sector}

Merchandise exports, f.o.b. ${ }^{2}$

Merchandise imports, f.o.b. ${ }^{2}$

Export (goods and services) volume

Import (goods and services) volume

Terms of trade

Nominal effective exchange rate (period average) ${ }^{3}$

Real effective exchange rate (period average) ${ }^{3}$

\section{Money and credit}

Net domestic assets ${ }^{4}$

Broad money (including foreign exchange deposits)

Velocity (GDP/average broad money)

Bank rate/repurchase rate (end of period, percent) ${ }^{5}$

\section{Investment and saving}

Investment (including inventories)

Of which: public fixed investment (including public enterprises) private fixed investment

Gross national saving

Public (including public enterprises)

Private

National government budget ${ }^{6}$

Revenue, including grants

Expenditure and net lending

Overall balance

National government debt

Borrowing requirement of the nonfinancial public sector

\section{External sector}

Current account balance

Overall balance of payments

Total external debt

Gross reserves (SARB, billions of U.S. dollars)

(months of next year's total imports)

(Annual percent change, unless otherwise indicated)

$\begin{array}{rrrrrrr}3.1 & 4.9 & 5.0 & 5.4 & 5.1 & 3.8 & 3.7 \\ 2.1 & 3.8 & 4.0 & 4.3 & 4.1 & 2.8 & 2.7 \\ 5.2 & 7.9 & 5.7 & 9.2 & 6.0 & 4.2 & 4.1 \\ 4.6 & 5.5 & 5.2 & 7.2 & 8.9 & 11.6 & 9.7 \\ 5.8 & 1.4 & 3.4 & 4.7 & 7.1 & 11.3 & 9.2 \\ 4.0 & 4.3 & 4.0 & 5.0 & 8.6 & 11.6 & 8.1\end{array}$

$\begin{array}{rrrrrrr}28.0 & 26.2 & 26.7 & 25.5 & 23.0 & 22.9 & 22.9 \\ 8.4 & 9.1 & 7.1 & 7.5 & 6.7 & 11.2 & 11.2 \\ 5.0 & 2.7 & 3.9 & 2.7 & 2.5 & 2.7 & 2.8 \\ 3.2 & 6.2 & 3.2 & 4.7 & 4.0 & 8.2 & 8.1\end{array}$

$\begin{array}{rrrrrrr}21.6 & 25.0 & 15.0 & 16.0 & 18.3 & 20.5 & 5.0 \\ 30.1 & 38.1 & 16.6 & 25.0 & 15.9 & 28.3 & 8.0 \\ 0.1 & 2.9 & 8.0 & 5.6 & 8.3 & 3.5 & 5.0 \\ 8.1 & 14.5 & 10.3 & 18.8 & 10.4 & 4.9 & 5.8 \\ 3.8 & 0.8 & 0.6 & 4.3 & 3.3 & -2.2 & -1.6 \\ 25.1 & 9.1 & 1.1 & -5.6 & -9.7 & -16.3 & \ldots \\ 25.1 & 6.7 & 0.5 & -2.5 & -3.4 & -12.7 & \ldots\end{array}$

$\begin{array}{rrrrrrr}7.2 & 11.3 & 14.6 & 15.4 & 21.4 & 21.9 & 19.0 \\ 12.9 & 13.1 & 20.5 & 22.5 & 23.6 & 26.3 & 20.8 \\ 1.6 & 1.6 & 1.5 & 1.4 & 1.3 & 1.2 & 1.1 \\ 8.0 & 7.5 & 7.0 & 9.0 & 11.0 & 12.0 & \ldots\end{array}$

(Percent of GDP, unless otherwise indicated)

$\begin{array}{rrrrrrr}16.9 & 17.7 & 18.1 & 20.4 & 21.4 & 22.4 & 23.1 \\ 4.4 & 4.3 & 4.3 & 4.9 & 5.5 & 5.8 & 6.7 \\ 11.5 & 11.9 & 12.5 & 13.7 & 15.1 & 15.9 & 16.0 \\ 15.8 & 14.5 & 14.0 & 14.0 & 14.1 & 13.4 & 13.4 \\ 1.8 & 1.5 & 3.1 & 3.8 & 4.4 & 4.0 & 4.1 \\ 14.0 & 12.9 & 11.0 & 10.1 & 9.8 & 9.4 & 9.4\end{array}$

$\begin{array}{rrrrrrr}23.2 & 24.1 & 25.6 & 26.5 & 27.1 & 27.0 & 26.8 \\ 25.2 & 25.7 & 26.2 & 26.1 & 26.3 & 26.5 & 27.0 \\ -2.0 & -1.6 & -0.6 & 0.4 & 0.9 & 0.5 & -0.2 \\ 37.3 & 36.4 & 35.3 & 33.1 & 28.6 & 25.6 & 22.8 \\ 2.0 & 1.7 & -0.2 & -0.4 & -0.3 & 1.0 & 1.9\end{array}$

\begin{tabular}{rrrrrrr}
-1.1 & -3.2 & -4.0 & -6.5 & -7.3 & -9.0 & -9.6 \\
-0.4 & 2.7 & 2.2 & 1.7 & 2.4 & 1.2 & 0.9 \\
23.6 & 20.8 & 19.1 & 22.2 & 26.6 & 29.6 & 31.2 \\
8.0 & 14.7 & 20.6 & 25.6 & 33.0 & 36.6 & 39.6 \\
1.6 & 2.6 & 2.9 & 3.1 & 3.2 & 3.3 & 3.3 \\
\hline
\end{tabular}

Sources: South African Reserve Bank (SARB); IMF, International Financial Statistics; and IMF staff projections.

${ }^{1} \mathrm{CPIX}$ is the consumer price index (CPI) excluding the interest on mortgage loans. It is the targeted definition of inflation.

${ }^{2}$ In U.S. dollars; annual percent change.

${ }^{3}$ For 2008, April relative to December 2007

${ }^{4}$ Contribution (in percentage points) to the growth of broad money.

${ }^{5}$ For 2008 , as of July 31 .

${ }^{6}$ Calendar-year figures, based on staff's fiscal and GDP projections for 2008 and 2009.

\section{CInternational Monetary Fund. Not for Redistribution}


Table 2. South Africa: Selected Economic and Financial Indicators in the Medium Term, 2006-13

\begin{tabular}{|c|c|c|c|c|c|c|c|c|}
\hline & 2006 & 2007 & $\begin{array}{c}2008 \\
\text { Proj. }\end{array}$ & $\begin{array}{c}2009 \\
\text { Proj. }\end{array}$ & $\begin{array}{l}2010 \\
\text { Proj. }\end{array}$ & $\begin{array}{l}2011 \\
\text { Proj. }\end{array}$ & $\begin{array}{c}2012 \\
\text { Proj. }\end{array}$ & $\begin{array}{r}2013 \\
\text { Proj. }\end{array}$ \\
\hline & \multicolumn{8}{|c|}{ (Annual percent change, unless otherwise indicated) } \\
\hline \multicolumn{9}{|l|}{ National income and prices } \\
\hline Real GDP & 5.4 & 5.1 & 3.8 & 3.7 & 4.4 & 4.8 & 5.0 & 5.0 \\
\hline Real GDP per capita & 4.3 & 4.1 & 2.8 & 2.7 & 3.4 & 3.7 & 3.9 & 4.0 \\
\hline Real domestic demand & 9.2 & 6.0 & 4.2 & 4.1 & 5.0 & 4.9 & 5.1 & 5.0 \\
\hline GDP deflator & 7.2 & 8.9 & 11.6 & 9.7 & 7.4 & 5.5 & 4.9 & 4.8 \\
\hline CPI (annual average) & 4.7 & 7.1 & 11.3 & 9.2 & 6.5 & 4.8 & 4.5 & 4.5 \\
\hline CPIX (end of period) ${ }^{1}$ & 5.0 & 8.6 & 11.6 & 8.1 & 5.9 & 4.5 & 4.5 & 4.5 \\
\hline \multicolumn{9}{|l|}{ Labor market } \\
\hline Unemployment rate (percent) & 25.5 & 23.0 & 22.9 & 22.9 & 22.0 & 20.6 & 19.3 & 18.0 \\
\hline Average remuneration (formal nonagricultural sector) & 7.5 & 6.7 & 11.2 & 11.2 & 9.9 & 8.1 & 7.6 & 7.6 \\
\hline Labor productivity (formal nonagricultural sector) & 2.7 & 2.5 & 2.7 & 2.8 & 2.9 & 2.8 & 3.0 & 3.0 \\
\hline Nominal unit labor costs (formal nonagricultural sector) & 4.7 & 4.0 & 8.2 & 8.1 & 6.8 & 5.2 & 4.6 & 4.5 \\
\hline \multicolumn{9}{|l|}{ External sector } \\
\hline Merchandise exports, f.o.b. ${ }^{2}$ & 16.0 & 18.3 & 20.5 & 5.0 & 5.9 & 6.9 & 7.1 & 7.0 \\
\hline Merchandise imports, f.o.b. ${ }^{2}$ & 25.0 & 15.9 & 28.3 & 8.0 & 7.7 & 7.2 & 7.4 & 7.2 \\
\hline Export (goods and services) volume & 5.6 & 8.3 & 3.5 & 5.0 & 5.3 & 6.0 & 6.0 & 6.1 \\
\hline Import (goods and services) volume & 18.8 & 10.4 & 4.9 & 5.8 & 6.9 & 6.1 & 6.2 & 5.9 \\
\hline Terms of trade & 4.3 & 3.3 & -2.2 & -1.6 & 1.5 & 0.8 & 0.7 & 0.5 \\
\hline Nominal effective exchange rate ${ }^{3}$ & -5.6 & -9.7 & $\ldots$ & $\ldots$ & $\ldots$ & $\ldots$ & $\ldots$ & $\ldots$ \\
\hline Real effective exchange rate ${ }^{3}$ & -2.5 & -3.4 & $\ldots$ & $\ldots$ & $\ldots$ & $\ldots$ & $\ldots$ & $\ldots$ \\
\hline \multicolumn{9}{|l|}{ Money and credit } \\
\hline Net domestic assets ${ }^{4}$ & 15.4 & 21.4 & 21.9 & 19.0 & 17.7 & 16.5 & 16.2 & 16.0 \\
\hline Broad money (including foreign exchange deposits) & 22.5 & 23.6 & 26.3 & 20.8 & 18.9 & 17.7 & 17.2 & 16.9 \\
\hline Velocity (GDP/average broad money) & 1.4 & 1.3 & 1.2 & 1.1 & 1.1 & 1.0 & 0.9 & 0.9 \\
\hline Bank rate/repurchase rate (period end, in percent) & 9.0 & 11.0 & $\ldots$ & $\ldots$ & $\cdots$ & $\ldots$ & $\ldots$ & $\ldots$ \\
\hline & \multicolumn{8}{|c|}{ (Percent of GDP, unless otherwise indicated) } \\
\hline \multicolumn{9}{|l|}{ Investment and saving } \\
\hline Investment (including inventories) & 20.4 & 21.4 & 22.4 & 23.1 & 23.5 & 23.7 & 23.9 & 23.9 \\
\hline Of which: public fixed investment (including public enterprises) & 4.9 & 5.5 & 5.8 & 6.7 & 6.8 & 6.8 & 6.8 & 6.8 \\
\hline private fixed investment & 13.7 & 15.1 & 15.9 & 16.0 & 16.1 & 16.3 & 16.4 & 16.6 \\
\hline Gross national saving & 14.0 & 14.1 & 13.4 & 13.4 & 14.1 & 14.4 & 14.8 & 14.9 \\
\hline Public (including public enterprises) & 3.8 & 4.4 & 4.0 & 4.1 & 4.3 & 4.4 & 4.4 & 4.4 \\
\hline Private & 10.1 & 9.8 & 9.4 & 9.4 & 9.7 & 10.0 & 10.4 & 10.5 \\
\hline \multicolumn{9}{|l|}{ National government budget ${ }^{5}$} \\
\hline Revenue, including grants & 26.5 & 27.1 & 27.0 & 26.8 & 26.9 & 26.8 & 26.8 & 26.8 \\
\hline Expenditure and net lending & 26.1 & 26.3 & 26.5 & 27.0 & 26.7 & 26.4 & 26.4 & 26.4 \\
\hline Overall balance & 0.4 & 0.9 & 0.5 & -0.2 & 0.2 & 0.4 & 0.4 & 0.4 \\
\hline National government debt & 33.1 & 28.6 & 25.6 & 22.8 & 20.7 & 18.8 & 17.2 & 15.7 \\
\hline Borrowing requirement of the nonfinancial public sector & -0.4 & -0.3 & 1.0 & 1.9 & 1.5 & 1.4 & 1.4 & 1.4 \\
\hline \multicolumn{9}{|l|}{ External sector } \\
\hline Current account balance & -6.5 & -7.3 & -9.0 & -9.6 & -9.5 & -9.3 & -9.1 & -8.9 \\
\hline Overall balance of payments & 1.7 & 2.4 & 1.2 & 0.9 & 0.8 & 0.8 & 0.7 & 0.7 \\
\hline Total external debt & 22.2 & 26.6 & 29.6 & 31.2 & 32.8 & 35.0 & 34.7 & 34.9 \\
\hline Gross reserves (SARB, billions of U.S. dollars) & 25.6 & 33.0 & 36.6 & 39.6 & 42.6 & 45.6 & 48.6 & 51.6 \\
\hline (months of next year's total imports) & 3.1 & 3.2 & 3.3 & 3.3 & 3.3 & 3.3 & 3.3 & 3.3 \\
\hline
\end{tabular}

Sources: South African Reserve Bank (SARB); IMF, International Financial Statistics; and IMF staff projections.

${ }^{1} \mathrm{CPIX}$ is the consumer price index (CPI) excluding the interest on mortgage loans. It is the targeted definition of inflation.

${ }^{2}$ In U.S. dollars; annual percent change.

${ }^{3}$ Annual average, South African Reserve Bank.

${ }^{4}$ Contribution (in percentage points) to the growth of broad money.

${ }^{5}$ Calendar-year figures, based on staff's fiscal and GDP projections. 
Table 3. South Africa: National Government Main Budget, 2004/05-2010/11 ${ }^{1}$

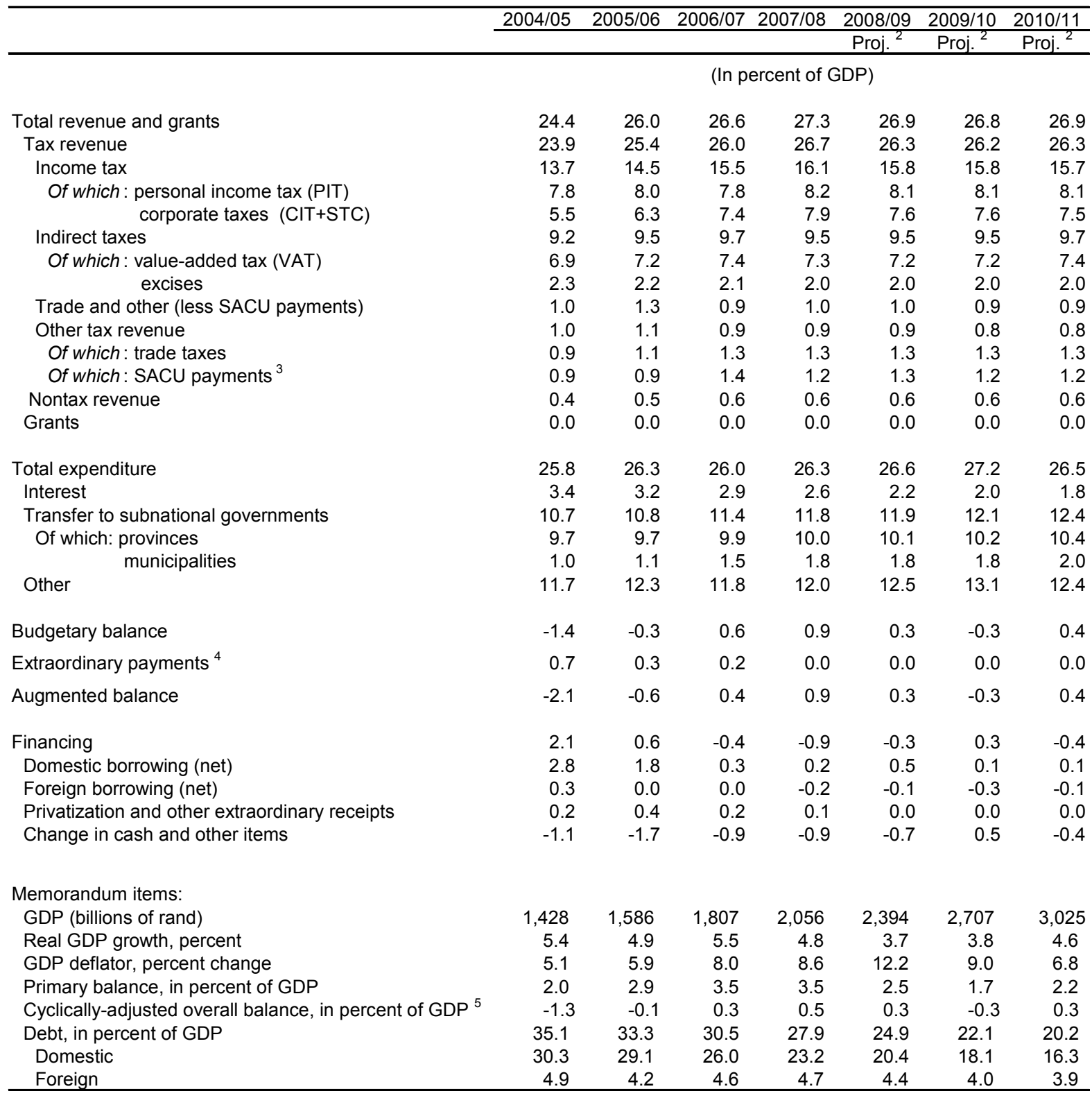

Sources: South African authorities; and IMF staff estimates and projections.

${ }^{1}$ For fiscal year beginning April 1. National government comprises the central government and subnational spending financed by transfers from the national revenue fund.

${ }^{2}$ Staff projections based on the 2008 Budget Review, discussions with the authorities, and staff estimates.

${ }^{3}$ Southern African Customs Union (SACU) payments are based on a revenue-sharing formula.

${ }^{4}$ Provision of bonds to the South African Reserve Bank in settlement of the Gold and Foreign Exchange Contingency Account.

${ }^{5}$ Before extraordinary payments. 
Table 4. South Africa: Nonfinancial Public Sector Operations, 2004/05-2010/11 ${ }^{1}$

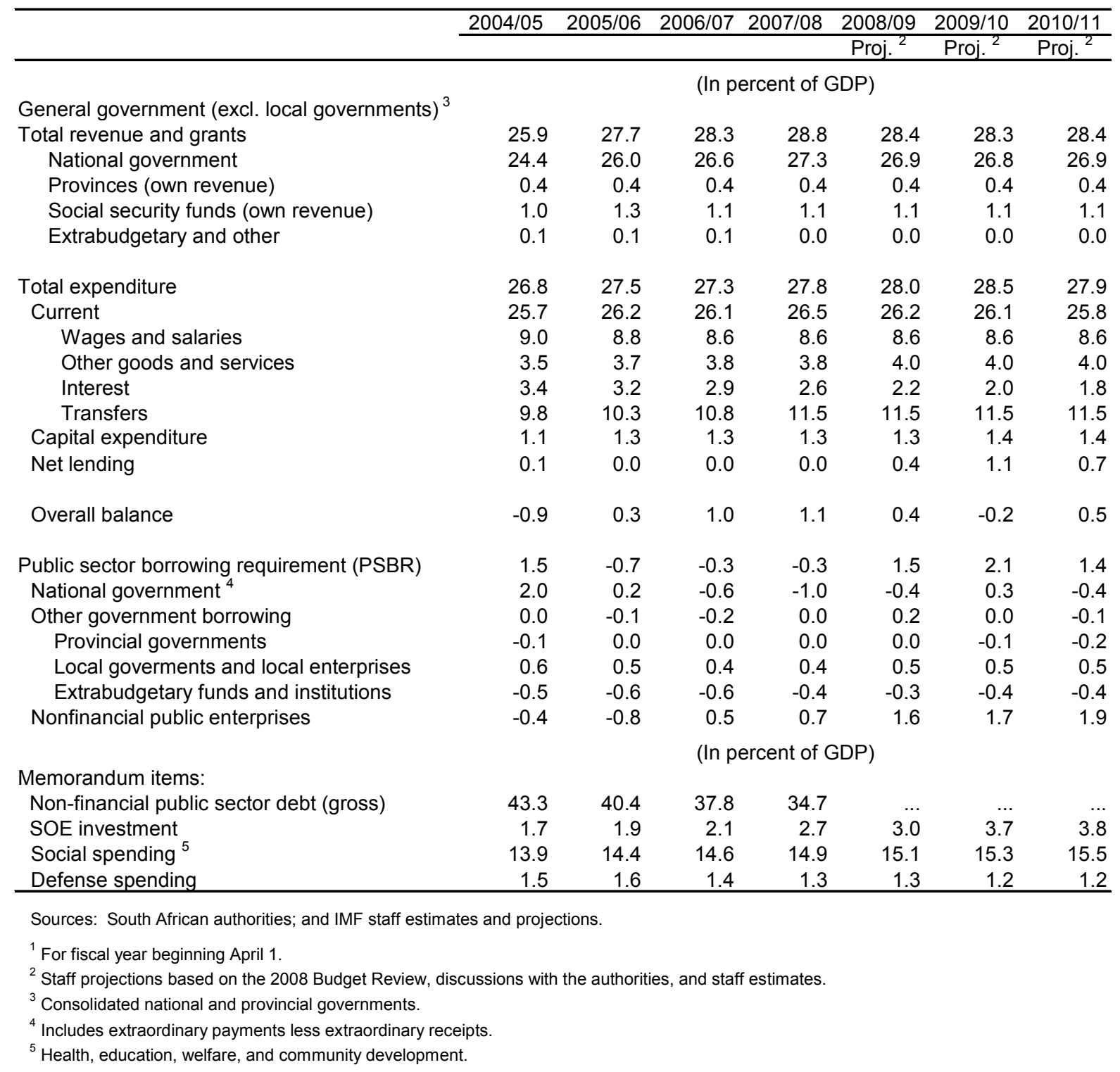


Table 5. South Africa: Balance of Payments, 2006-13

\begin{tabular}{|c|c|c|c|c|c|c|c|c|}
\hline & 2006 & 2007 & 2008 & 2009 & 2010 & 2011 & 2012 & 2013 \\
\hline & & & Proj. & Proj. & Proj. & Proj. & Proj. & Proj. \\
\hline & \multicolumn{8}{|c|}{ (Billions of U.S. dollars) } \\
\hline Balance on current account & -16.6 & -20.6 & -26.9 & -31.7 & -34.0 & -35.9 & -38.0 & -40.2 \\
\hline Balance on goods and services & -8.5 & -8.8 & -14.9 & -18.8 & -20.2 & -20.7 & -21.3 & -21.8 \\
\hline Exports of goods and services & 76.2 & 89.5 & 108.6 & 114.3 & 122.6 & 131.9 & 142.0 & 152.7 \\
\hline Exports of goods & 64.2 & 75.9 & 91.5 & 96.1 & 101.8 & 108.8 & 116.5 & 124.7 \\
\hline Nongold & 59.0 & 70.3 & 84.5 & 89.4 & 95.0 & 102.0 & 109.6 & 117.8 \\
\hline Gold & 5.2 & 5.7 & 7.0 & 6.7 & 6.7 & 6.9 & 7.0 & 7.0 \\
\hline Exports of services & 12.0 & 13.5 & 17.1 & 18.2 & 20.9 & 23.1 & 25.4 & 28.0 \\
\hline Imports of goods and services & -84.7 & -98.2 & -123.5 & -133.1 & -142.8 & -152.5 & -163.3 & -174.5 \\
\hline Imports of goods & -70.4 & -81.6 & -104.7 & -113.1 & -121.8 & -130.5 & -140.1 & -150.2 \\
\hline Imports of services & -14.3 & -16.6 & -18.7 & -20.0 & -21.0 & -22.0 & -23.2 & -24.3 \\
\hline Balance on income & -5.3 & -8.9 & -8.8 & -9.7 & -10.2 & -11.5 & -12.8 & -14.3 \\
\hline Income receipts & 5.9 & 6.5 & 7.5 & 8.4 & 9.4 & 9.8 & 10.6 & 11.4 \\
\hline Income payments & -11.2 & -15.4 & -16.3 & -18.0 & -19.7 & -21.3 & -23.4 & -25.7 \\
\hline Balance on transfers & -2.8 & -2.9 & -3.3 & -3.3 & -3.5 & -3.7 & -3.9 & -4.1 \\
\hline Capital flows (including errors and omissions) & 21.0 & 27.3 & 30.5 & 34.7 & 37.0 & 38.9 & 41.0 & 43.2 \\
\hline Balance on capital and financial account & 15.1 & 23.1 & 30.5 & 34.7 & 37.0 & 38.9 & 41.0 & 43.2 \\
\hline Balance on capital account & 0.0 & 0.0 & 0.0 & 0.0 & 0.0 & 0.0 & 0.0 & 0.0 \\
\hline Balance on financial account & 15.1 & 23.1 & 30.5 & 34.7 & 36.9 & 38.9 & 41.0 & 43.1 \\
\hline Direct investment & -7.3 & 2.0 & 4.5 & 2.4 & 2.6 & 2.9 & 3.1 & 3.4 \\
\hline Liabilities & -0.5 & 5.7 & 8.3 & 6.3 & 6.6 & 6.9 & 7.2 & 7.6 \\
\hline Assets & -6.7 & -3.7 & -3.8 & -3.9 & -4.0 & -4.0 & -4.1 & -4.2 \\
\hline Portfolio investment & 19.1 & 11.8 & 12.5 & 13.8 & 15.0 & 16.1 & 17.4 & 18.8 \\
\hline Liabilities & 21.3 & 15.2 & 16.2 & 17.8 & 19.3 & 20.8 & 22.5 & 24.2 \\
\hline Assets & -2.2 & -3.4 & -3.6 & -4.0 & -4.3 & -4.7 & -5.1 & -5.4 \\
\hline Other investment & 3.2 & 9.3 & 13.5 & 18.6 & 19.3 & 19.8 & 20.4 & 21.0 \\
\hline Liabilities & 9.5 & 8.2 & 8.7 & 9.6 & 10.5 & 11.3 & 12.2 & 13.1 \\
\hline Assets & -6.2 & 1.1 & 4.8 & 8.9 & 8.9 & 8.6 & 8.3 & 7.9 \\
\hline Errors and omissions & 5.9 & 4.2 & 0.0 & 0.0 & 0.0 & 0.0 & 0.0 & 0.0 \\
\hline Overall balance of payments & 4.4 & 6.8 & 3.6 & 3.0 & 3.0 & 3.0 & 3.0 & 3.0 \\
\hline Gross reserves (SARB) ${ }^{1}$ & 25.6 & 33.0 & 36.6 & 39.6 & 42.6 & 45.6 & 48.6 & 51.6 \\
\hline \multirow[t]{2}{*}{ International liquidity position of the SARB ${ }^{1,2}$} & 23.0 & 31.3 & 34.9 & 37.9 & 40.9 & 43.9 & 46.9 & 49.9 \\
\hline & \multicolumn{8}{|c|}{ (Percent of GDP, unless otherwise indicated) } \\
\hline Balance on current account & -6.5 & -7.3 & -9.0 & -9.6 & -9.5 & -9.3 & -9.1 & -8.9 \\
\hline Balance on goods and services & -3.3 & -3.1 & -5.0 & -5.7 & -5.6 & -5.3 & -5.1 & -4.9 \\
\hline Exports of goods and services & 29.6 & 31.6 & 36.2 & 34.6 & 34.2 & 34.1 & 34.0 & 34.0 \\
\hline Imports of goods and services & -32.9 & -34.7 & -41.2 & -40.3 & -39.8 & -39.4 & -39.2 & -38.8 \\
\hline Capital flows (including errors and omissions) & 8.2 & 9.7 & 10.2 & 10.5 & 10.3 & 10.0 & 9.8 & 9.6 \\
\hline Balance on capital and financial account & 5.9 & 8.2 & 10.2 & 10.5 & 10.3 & 10.0 & 9.8 & 9.6 \\
\hline Errors and omissions & 2.3 & 1.5 & 0.0 & 0.0 & 0.0 & 0.0 & 0.0 & 0.0 \\
\hline Overall balance of payments & 1.7 & 2.4 & 1.2 & 0.9 & 0.8 & 0.8 & 0.7 & 0.7 \\
\hline Gross reserves (SARB) $^{1}$ & 10.0 & 11.7 & 12.2 & 12.0 & 11.9 & 11.8 & 11.7 & 11.5 \\
\hline International liquidity position of the SARB ${ }^{1,2}$ & 8.9 & 11.1 & 11.6 & 11.5 & 11.4 & 11.3 & 11.2 & 11.1 \\
\hline \multicolumn{9}{|l|}{ Memorandum items: } \\
\hline Total external debt & 22.2 & 26.6 & 29.6 & 31.2 & 32.8 & 35.0 & 34.7 & 34.9 \\
\hline Foreign currency debt & 13.9 & 15.4 & 16.4 & 16.6 & 17.0 & 17.3 & 16.7 & 16.3 \\
\hline Of which: Short-term debt (at remaining maturity) & 6.6 & 6.6 & 7.5 & 7.4 & 7.4 & 7.5 & 7.0 & 6.7 \\
\hline Total external debt service (billions of U.S. dollars) & 6.3 & 7.9 & 8.8 & 10.1 & 10.6 & 11.7 & 17.5 & 17.8 \\
\hline Gold price (period average; U.S. dollar per ounce) & 604 & 697 & 910 & 895 & 935 & 980 & 1,025 & 1,050 \\
\hline Crude oil price (period average; U.S. dollar per barrel) & 64.3 & 71.1 & 116.5 & 125.0 & 123.5 & 123.5 & 123.5 & 123.8 \\
\hline
\end{tabular}

Sources: South African Reserve Bank (SARB) and IMF staff estimates and projections.

${ }^{1}$ End of period.

${ }^{2}$ Gross reserves minus foreign loans and minus forward position. The SARB's open position in the forward market was closed in February 2004. 
Table 6. South Africa: Monetary Survey, 2003-07

\begin{tabular}{|c|c|c|c|c|c|}
\hline & 2003 & 2004 & 2005 & 2006 & 2007 \\
\hline & Dec. & Dec. & Dec. & Dec. & Dec \\
\hline & \multicolumn{5}{|c|}{ (Billions of rand) } \\
\hline Net foreign assets & 126.7 & 141.4 & 195.2 & 274.3 & 304.5 \\
\hline Gross reserves & 214.5 & 229.6 & 297.8 & 409.8 & 561.7 \\
\hline SARB & 52.9 & 82.8 & 130.5 & 178.3 & 224.3 \\
\hline Other monetary institutions & 161.6 & 146.7 & 167.3 & 231.5 & 337.4 \\
\hline Liabilities & 87.8 & 88.2 & 102.6 & 135.5 & 257.2 \\
\hline SARB & 20.0 & 19.8 & 22.2 & 19.3 & $12 . c$ \\
\hline Other monetary institutions & 67.8 & 68.4 & 80.4 & 116.2 & 245.2 \\
\hline Net domestic assets & 681.4 & 772.8 & 906.0 & $1,075.0$ & $1,363.8$ \\
\hline Credit to government, net & 45.8 & 42.6 & 0.8 & -29.5 & -32.5 \\
\hline Claims on government & 104.2 & 116.1 & 107.4 & 112.4 & 116.5 \\
\hline Government deposits & 58.4 & 73.4 & 106.6 & 141.8 & 149.0 \\
\hline Credit to private sector ${ }^{1}$ & 838.3 & 954.0 & $1,140.0$ & $1,434.7$ & $1,744.2$ \\
\hline Other items, net & -202.7 & -223.9 & -234.8 & -330.2 & -347.9 \\
\hline Broad money (M3) & 808.0 & 914.2 & $1,101.1$ & $1,349.3$ & $1,668.3$ \\
\hline \multirow[t]{2}{*}{ Of which: M1 } & 387.8 & 421.5 & 503.1 & 605.7 & 739.1 \\
\hline & \multicolumn{5}{|c|}{ (Annual percentage change) } \\
\hline Net foreign assets & 46.8 & 11.6 & 38.0 & 40.5 & 11.0 \\
\hline Net domestic assets & 8.2 & 13.4 & 17.2 & 18.7 & 26.9 \\
\hline Credit to private sector & 19.2 & 13.8 & 19.5 & 25.8 & 21.6 \\
\hline \multirow[t]{2}{*}{ Broad money (M3) } & 12.9 & 13.1 & 20.5 & 22.5 & 23.6 \\
\hline & \multicolumn{5}{|c|}{ (Contribution to growth of M3, unless otherwise specified) } \\
\hline Net foreign assets & 5.6 & 1.8 & 5.9 & 7.2 & 2.2 \\
\hline Net domestic assets & 7.2 & 11.3 & 14.6 & 15.4 & 21.4 \\
\hline Credit to government, net & -1.7 & -0.4 & -4.6 & -2.7 & 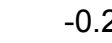 \\
\hline Credit to private sector ${ }^{1}$ & 18.8 & 14.3 & 20.3 & 26.8 & $22 . c$ \\
\hline Other items, net & -9.9 & -2.6 & -1.2 & -8.7 & -1.3 \\
\hline \multicolumn{6}{|l|}{ Memorandum item: } \\
\hline Income velocity of M3 & 1.65 & 1.61 & 1.52 & 1.40 & 1.30 \\
\hline
\end{tabular}

Source: South African Reserve Bank (SARB).

${ }^{1}$ Part of the increase in private sector credit in 2003 is due to a change in accounting rules for derivatives. 
Table 7. South Africa: Indicators of External Vulnerability, 2003-08

\begin{tabular}{|c|c|c|c|c|c|c|c|}
\hline & 2003 & 2004 & 2005 & 2006 & 2007 & 2008 & date \\
\hline & \multicolumn{7}{|c|}{ (Percent of GDP, unless otherwise specified) } \\
\hline \multicolumn{8}{|l|}{ Financial indicators } \\
\hline Government debt ${ }^{1}$ & 37.3 & 36.4 & 35.3 & 33.1 & 28.6 & & \\
\hline Broad money (percent change; 12-month basis) & 12.9 & 13.1 & 20.5 & 22.5 & 23.6 & 20.1 & June \\
\hline Private sector credit (percent change; 12-month basis) & 19.2 & 13.8 & 19.5 & 25.8 & 21.6 & 20.3 & June \\
\hline Repurchase rate (percent) ${ }^{2}$ & 8.0 & 7.5 & 7.0 & 9.0 & 11.0 & 12.0 & July \\
\hline Repurchase rate (percent; real) ${ }^{2,3}$ & 3.8 & 3.1 & 2.9 & 3.8 & 2.2 & 0.4 & June \\
\hline \multicolumn{8}{|l|}{ External indicators } \\
\hline Exports of goods and services (percent change; US\$ value) & 27.5 & 23.6 & 15.1 & 14.6 & 17.4 & $\ldots$ & \\
\hline Imports of goods and services (percent change; US\$ value) & 32.7 & 36.5 & 16.9 & 23.7 & 15.9 & $\ldots$ & \\
\hline Terms of trade (percent change) & 3.8 & 0.8 & 0.6 & 4.3 & 3.3 & $\ldots$ & \\
\hline Current account balance & -1.1 & -3.2 & -4.0 & -6.5 & -7.3 & $\ldots$ & \\
\hline Capital and financial account balance & -1.1 & 3.3 & 4.9 & 5.9 & 8.2 & & \\
\hline${\text { Gross official reserves (US\$ billion) }{ }^{2}}^{2}$ & 8.0 & 14.7 & 20.6 & 25.6 & 33.0 & 35.0 & July \\
\hline Short-term foreign liabilities of SARB (US\$ billion) ${ }^{2}$ & 0.5 & 0.4 & 0.7 & 2.6 & 1.7 & 0.8 & July \\
\hline International liquidity position of SARB (US\$ billion) ${ }^{2,4}$ & 4.8 & 11.4 & 17.2 & 23.0 & 31.3 & 34.2 & July \\
\hline Short-term external debt plus open forward position (US\$ billion) & 11.7 & 10.4 & 14.1 & 17.0 & 18.6 & $\ldots$ & \\
\hline Gross official reserves as a percent of the above & 68.0 & 141.2 & 145.9 & 150.5 & 177.5 & $\ldots$ & \\
\hline Foreign currency-denominated external debt (US\$ billion) & 27.3 & 27.9 & 28.1 & 35.8 & 43.6 & $\ldots$ & \\
\hline As a percent of total exports & 58.5 & 48.3 & 42.2 & 46.9 & 48.8 & $\ldots$ & \\
\hline External interest payments (as a percent of total exports) & 4.6 & 3.8 & 3.8 & 3.5 & 3.8 & $\ldots$ & \\
\hline Exchange rate (per U.S. dollar; period average) ${ }^{5}$ & 7.56 & 6.45 & 6.36 & 6.77 & 7.05 & 7.64 & July \\
\hline Real effective exchange rate appreciation (period average; percent) ${ }^{6}$ & 25.1 & 6.7 & 0.5 & -2.5 & -3.4 &. & \\
\hline \multicolumn{8}{|l|}{ Financial market indicators ${ }^{2}$} \\
\hline Stock market index $(1994=100)^{5}$ & 175 & 213 & 303 & 419 & 487 & 466 & July \\
\hline Percent change $^{5}$ & 12.0 & 21.9 & 42.6 & 38.0 & 16.2 & -4.3 & July \\
\hline Foreign currency debt rating-Standard \& Poor's & BBB & BBB & BBB + & BBB + & BBB+ & $\mathrm{BBB}+$ & July \\
\hline Foreign currency debt rating-Moody's & Baa2 & Baa2 & Baa1 & Baa1 & Baa1 & Baa1 & July \\
\hline Spread of benchmark bonds (basis points) ${ }^{7}$ & 149 & 101 & 84 & 87 & 166 & 227 & July \\
\hline \multicolumn{8}{|l|}{ Sources: South African Reserve Bank (SARB) and IMF staff estimates. } \\
\hline \multicolumn{8}{|l|}{${ }^{1}$ National government debt, end of period. } \\
\hline \multicolumn{8}{|l|}{${ }^{2}$ End of period. } \\
\hline \multicolumn{8}{|c|}{${ }^{3}$ Deflated by the percent change in end-period CPIX (consumer price index less interest on mortgage loans). } \\
\hline \multirow{2}{*}{\multicolumn{8}{|c|}{$\begin{array}{l}{ }^{4} \text { Gross reserves minus foreign loans and minus forward position. The SARB's open position in the forward market was closed } \\
\text { in February } 2004 .\end{array}$}} \\
\hline & & & & & & & \\
\hline \multicolumn{8}{|l|}{${ }^{6}$ SARB. } \\
\hline \multicolumn{8}{|c|}{${ }^{7}$ Until end-2005: a 2017 US $\$$ denominated bond vs. a comparable synthetic U.S. bond from Merrill Lynch; } \\
\hline
\end{tabular}


Table 8: South Africa: Financial Soundness Indicators, 2002-07

\begin{tabular}{|c|c|c|c|c|c|c|}
\hline & 2002 & 2003 & 2004 & 2005 & 2006 & 2007 \\
\hline & \multicolumn{6}{|c|}{ (Percent, unless otherwise indicated) } \\
\hline \multicolumn{7}{|l|}{ Capital adequacy: } \\
\hline Regulatory capital to risk-weighted assets ${ }^{1}$ & 12.6 & 12.4 & 14.0 & 12.7 & 12.3 & 12.8 \\
\hline Regulatory tier 1 capital to risk-weighted assets ${ }^{1}$ & 8.7 & 8.9 & 10.5 & 9.7 & 9.0 & 9.5 \\
\hline \multicolumn{7}{|l|}{ Asset quality: } \\
\hline Nonperforming loans to total gross loans ${ }^{2}$ & 2.9 & 2.4 & 1.8 & 1.5 & 1.1 & 1.4 \\
\hline Nonperforming loans net of provisions to capital ${ }^{2}$ & 13.2 & 8.5 & 6.2 & 6.4 & 5.6 & 8.2 \\
\hline Share of mortgage advances in domestic private credit $^{3}$ & 40.7 & 39.6 & 43.3 & 46.2 & 47.7 & 48.9 \\
\hline \multicolumn{7}{|l|}{ Earnings and profitability: } \\
\hline Return on assets (average) & 0.4 & 0.8 & 1.3 & 1.2 & 1.4 & 1.4 \\
\hline Return on equity (average) & 5.4 & 11.6 & 16.2 & 15.2 & 18.3 & 18.1 \\
\hline Interest margin to gross income & 52.3 & 38.3 & 41.6 & 38.2 & 43.8 & 58.5 \\
\hline Noninterest expenses to gross income & 60.4 & 74.8 & 68.5 & 61.5 & 48.5 & 48.9 \\
\hline \multicolumn{7}{|l|}{ Liquidity: } \\
\hline Liquid assets to total assets & 4.7 & 4.7 & 4.7 & 4.8 & 4.6 & 4.6 \\
\hline Share of short-term deposits in total deposits & 47.9 & 45.7 & 43.7 & 43.5 & 42.8 & 42.5 \\
\hline \multicolumn{7}{|l|}{ Exposure to FX risk: } \\
\hline Maximum effective net open FX position to capital & 3.6 & 1.3 & 0.8 & 1.9 & 1.4 & 0.7 \\
\hline Share of foreign currency loans in total lending & 13.6 & 11.9 & 10.9 & 11.1 & 11.4 & 9.3 \\
\hline Share of foreign currency deposits in total deposits ${ }^{4}$ & 4.4 & 2.7 & 2.7 & 2.7 & 3.3 & 3.0 \\
\hline Share of foreign liabilities in total liabilities ${ }^{5}$ & 6.3 & 3.8 & 4.0 & 4.2 & 5.3 & 6.0 \\
\hline
\end{tabular}

Source: South African Reserve Bank.

${ }^{1}$ Total (banking and trading book).

${ }^{2}$ The official definition of nonperforming loans comprises doubtful and loss loans. Doubtful are loans overdue for 180 days unless well secured, or with a timely realization of the collateral.

${ }^{3}$ Domestic private credit not seasonally adjusted.

${ }^{4}$ Foreign funding to total funding.

${ }^{5}$ Foreign funding to total liabilities (including capital). 
Table 9. South Africa: Social and Demographic Indicators

(2007, unless otherwise specified)

\section{Area}

1.22 million square kilometers

Population characteristics

Population density

Urban population

(percentage of total, 2005)

Proportion in capital city as a percentage of urban population (census 2001)

Population age structure (percent)

$$
0-14 \text { years }
$$

$15-64$

65 and above

Population below $\$ 2$ a day, PPP basis

(percent of population, 2000)

GDP per capita at current prices

In U.S. dollars

\section{Nutrition (1999)}

Per capita calorie intake per day

Mean

Median
5,907

2,424

2,358

32

63

5

34.1

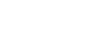

\section{Population}

Total (September 2007)

47.9 million

Annual rate of growth

1.0 percent

Health

Life expectancy at birth

Total (years, 2005)

58

8

Infant mortality per thousand

live births (2005)

54

\section{Labor force}

Female (percentage of labor force)

46
Percentage of employment

(September 2007)

Agriculture

Mining

Industry ${ }^{1}$

3.4

Trade

22.5

Other services

22.3

43.0

\section{Education}

Adult literacy $(15+$, percentage)

Male

Female

81

Total

82

Sources: World Bank, World Development Indicators; UNDP, Human Development Report; Statistics South Africa; and IMF staff estimates.

${ }^{1}$ Comprises the manufacturing, construction, and utilities sectors. 
Table 10. South Africa: Millennium Development Goals, 1990-2006 ${ }^{1}$

1. Eradicate extreme poverty and hunger
Population below $\$ 1$ a day ( $\%)$
Poverty gap at $\$ 1$ a day (\%)
Percentage share of income or consumption held by poorest $20 \%$
Prevalence of child malnutrition ( $\%$ of children under 5 )
Population below minimum level of dietary energy consumption (\%)

\section{Achieve universal primary education}

Net primary enrollment ratio (\% of relevant age group)

Youth literacy rate (\% ages 15-24)

\section{Promote gender equality}

Ratio of girls to boys in primary and secondary education (\%)

Ratio of young literate females to males (\% ages 15-24)

Share of women employed in the nonagricultural sector (\%)

Proportion of seats held by women in national parliament (\%)

990

1995

2000

2003

2006

2015 target $=$ halve $1990 \$ 1$ a day poverty and malnutrition rates

$\begin{array}{rrrrr}\ldots & 6.3 & 10.7 & \ldots & \ldots \\ \ldots & 0.6 & 1.7 & \ldots & \ldots \\ \ldots & 3.6 & 3.5 & \ldots & \ldots \\ \ldots & 9.2 & \ldots & \ldots & \ldots \\ \ldots & 3.0 & \ldots & \ldots & 3.0\end{array}$

\section{Reduce child mortality}

Under 5 mortality rate (per 1,000)

Infant mortality rate (per 1,000 live births)

Immunization, measles (\% of children under 12 months)

\section{Improve maternal health}

Maternal mortality ratio (modeled estimate, per 100,000 live births)

Births attended by skilled health staff ( $\%$ of total)

\section{Combat HIVIAIDS, malaria and other diseases}

Prevalence of HIV (\% ages 15-49)

Contraceptive prevalence rate (\% of women ages 15-49)

Number of children orphaned by HIVIAIDS (thousands)

Incidence of tuberculosis (per 100,000 people)

Tuberculosis cases detected under DOTS (\%)

\section{Ensure environmental sustainability}

Forest area (\% of total land area)

Nationally protected areas (\% of total land area)

GDP per unit of energy use (2000 PPP \$ per kg oil equivalent)

$\mathrm{CO} 2$ emissions (metric tons per capita)

Access to an improved water source (\% of population)

Access to improved sanitation (\% of population)

\section{Develop a Global Partnership for Development}

Youth unemployment rate (\% of total labor force ages 15-24)

Fixed line and mobile telephones (per 1,000 people) ${ }^{2}$

Personal computers (per 1,000 people) ${ }^{2}$

\section{General indicators}

Adult literacy rate (\% of people ages 15 and over)

Total fertility rate (births per woman) ${ }^{2}$

Life expectancy at birth (years) ${ }^{2}$

2015 target $=$ reduce 1990 under 5 mortality by two-thirds

$\begin{array}{lllll}60.0 & 59.0 & 63.0 & 66.0 & 69.0 \\ 45.0 & 45.0 & 50.0 & 53.0 & 56.0 \\ 79.0 & 76.0 & 77.0 & 83.0 & 85.0\end{array}$

2015 target $=$ reduce 1990 maternal mortality by three-fourths

$$
\begin{array}{rrrrr}
\ldots & \ldots & 230.0 & \ldots & 400.0 \\
\ldots & 82.0 & 84.0 & \ldots & \ldots
\end{array}
$$

2015 target $=$ halt and begin to reverse prevalence of diseases

$\begin{array}{lllll}\ldots & \ldots & \ldots & 19.0 & 18.8\end{array}$

$\begin{array}{lllll}57.0 & \ldots & \ldots & \ldots & 14.8\end{array}$

$\begin{array}{rrrrr}\ldots & \ldots & \ldots & \ldots & \ldots \\ 224.0 & 392.4 & 465.0 & 536.4 & 940.0\end{array}$

$\begin{array}{rrrrr}\ldots & 6.0 & 58.0 & \ldots & 71.0\end{array}$

\begin{tabular}{ccccc}
\multicolumn{7}{c}{2015 target $=$} & various & & \\
& & & \\
7.6 & 8.0 & 7.3 & $\ldots$ & 8.0
\end{tabular}

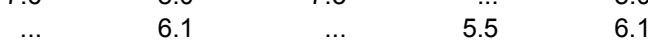

$\begin{array}{rrrrr}\ldots & \ldots & 3.8 & 3.9 & \ldots \\ 9.4 & \ldots & 9.0 & & 9.4\end{array}$

$\begin{array}{rrrrr}83.0 & 8 & \ldots & \\ 64.0 & \ldots & 87.0 & 88.0\end{array}$

$\begin{array}{llll}69.0 & 68.0 & 66.0 & 67.0\end{array}$

\begin{tabular}{rrrrr}
\multicolumn{5}{c}{2015 target $=$ various ${ }^{1}$} \\
$\ldots$ & $\ldots$ & 44.2 & 60.1 & $\ldots$ \\
94.3 & 116.0 & 302.3 & 473.1 & 825.1 \\
7.1 & 28.1 & 66.4 & 72.6 & 84.6
\end{tabular}

Sources: World Bank and Statistics South Africa.

Note: In some cases the data are for earlier or later years than those stated.

${ }^{1}$ For definitions of Goal 7 and 8 targets, see http://ddp-ext.worldbank.org/ext/GMIS/gdmis.do.

2005 figures. 
Figure 1. South Africa: Real Sector Developments
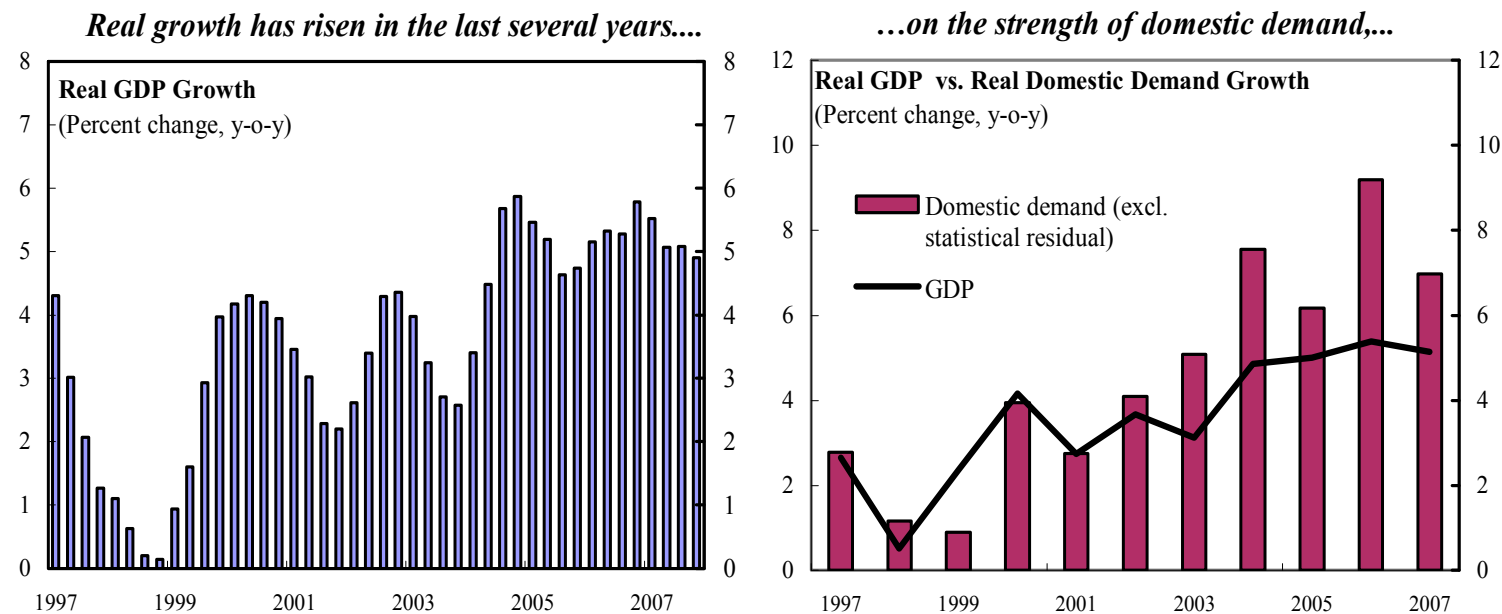

... remaining, however, moderate relative to the fast-growing emerging markets.
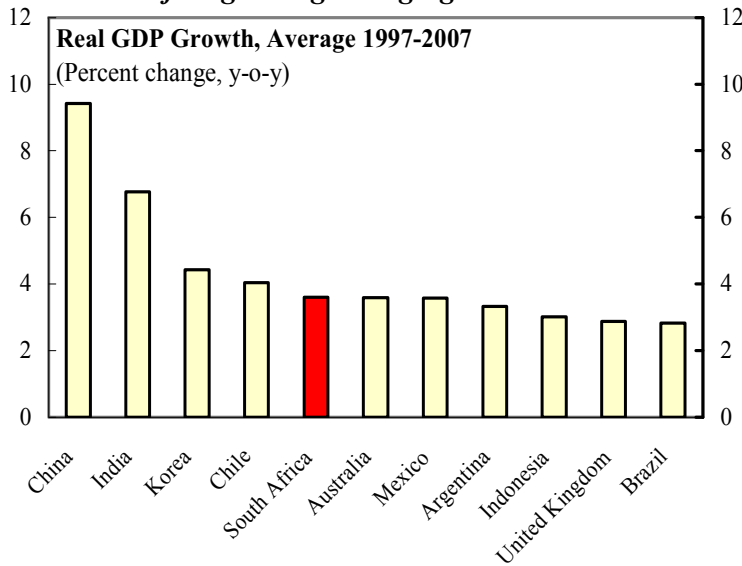

Employment has been growing...

Investment sped up, but saving declined.

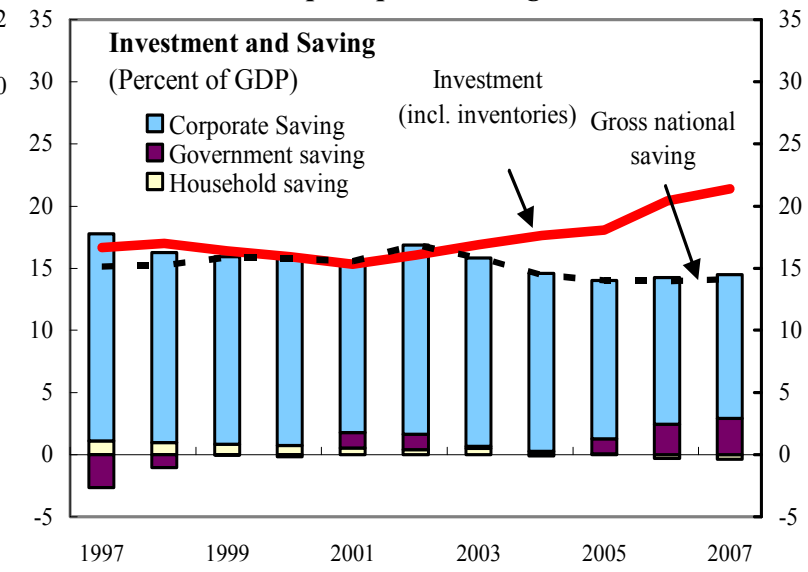

...and unemployment started declining, but still remains high.
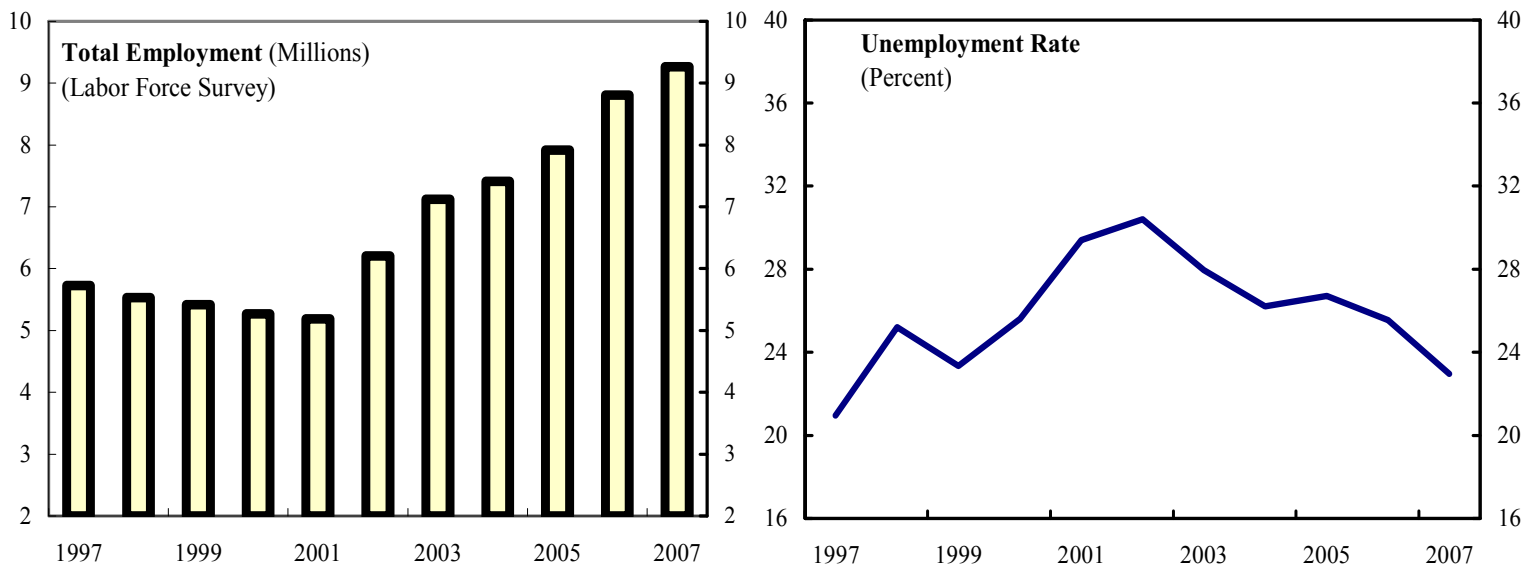

Sources: SARB and IMF. 
Figure 2. South Africa: Exchange Rates, Asset Prices and Spreads

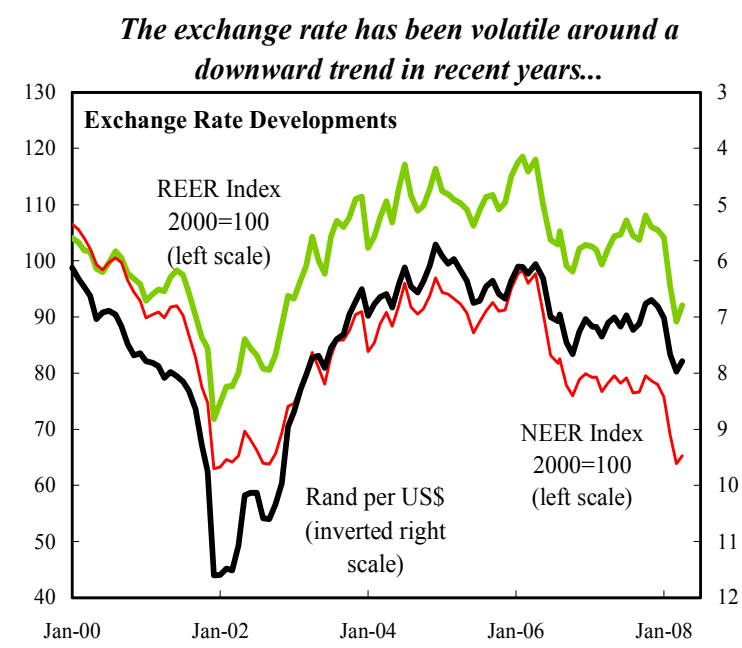

...despite sharp rises in the prices of main export commodities.

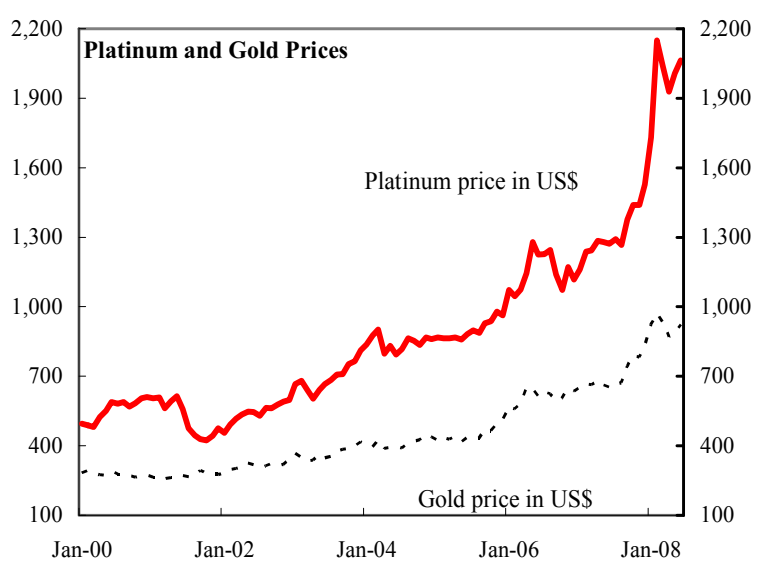

...and sovereign spreads have widened...

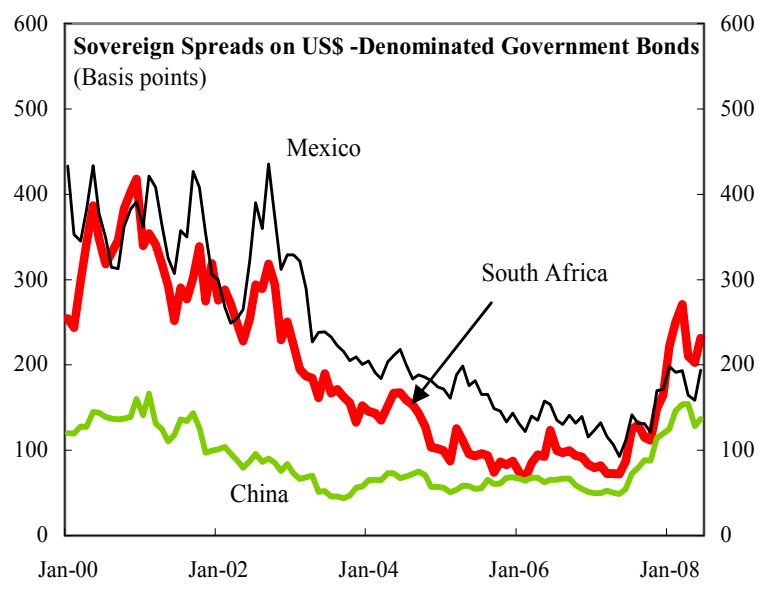

Sources: SARB, Datastream, Absa, and IMF. ...and the REER has depreciated relative to currencies of other commodity exporters...

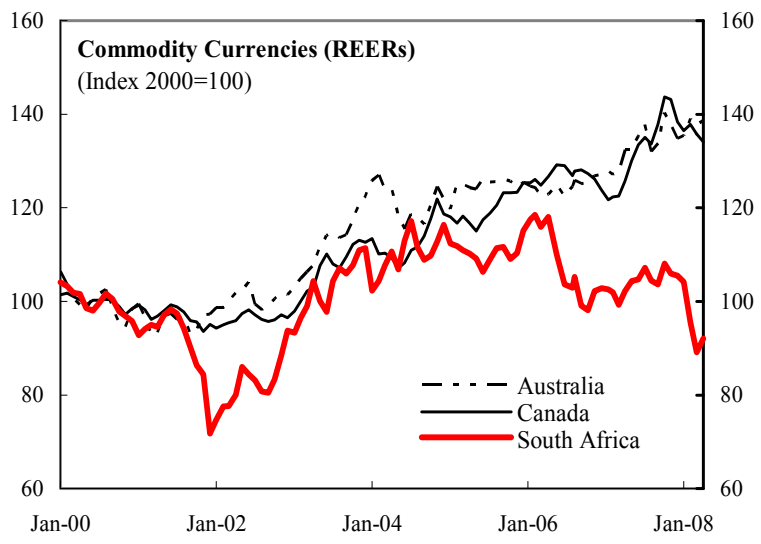

Equities prices have been volatile lately..

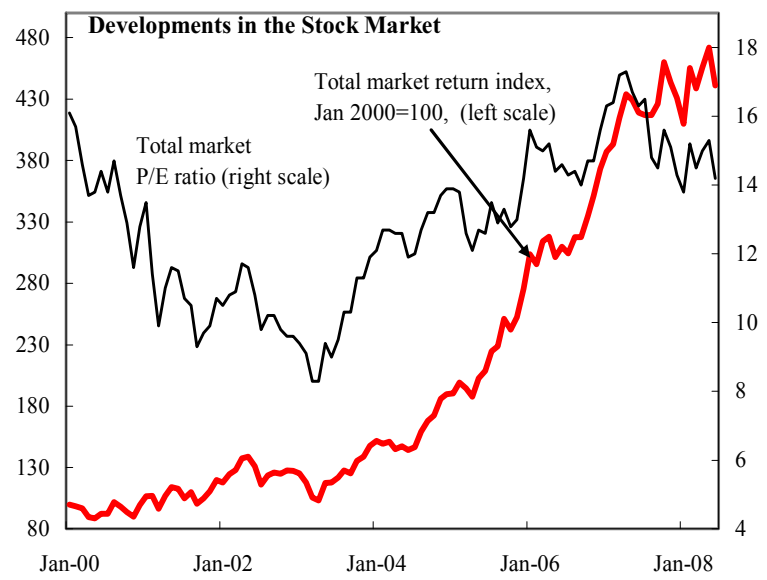

...closing the gap with an emerging market index.

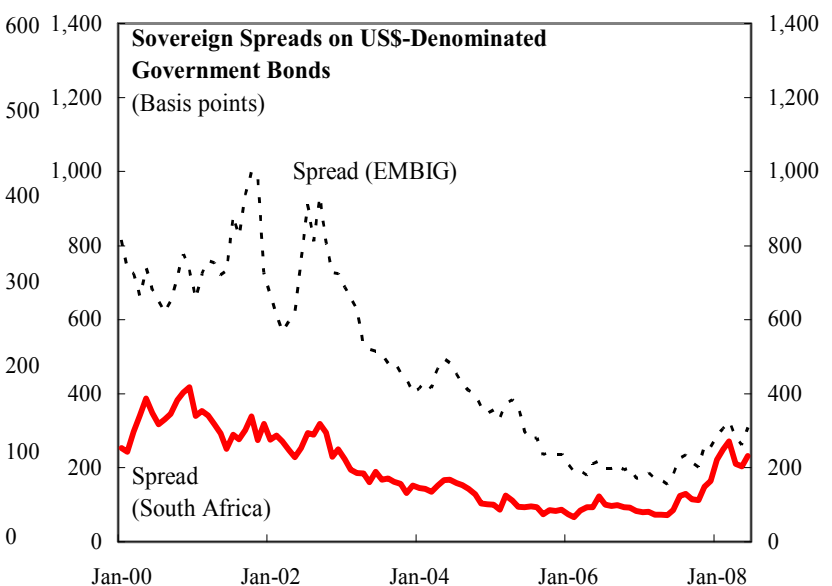


Figure 3. South Africa: Money, Prices and Interest Rates

Money and credit flows have begun to moderate...

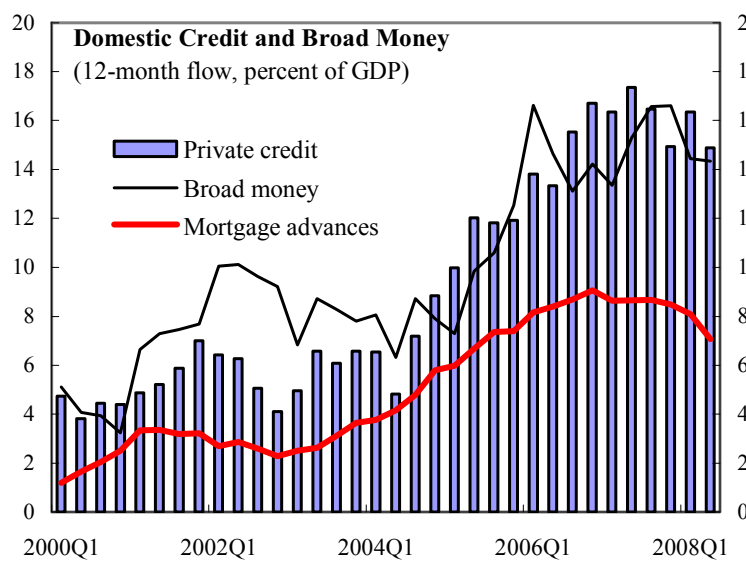

Inflation has been rising ...

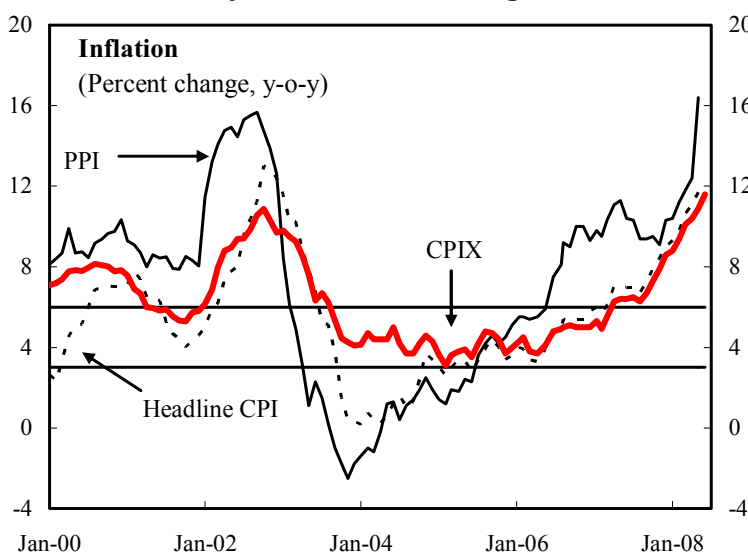

Short-term bond yields have caught up with the repo rate...

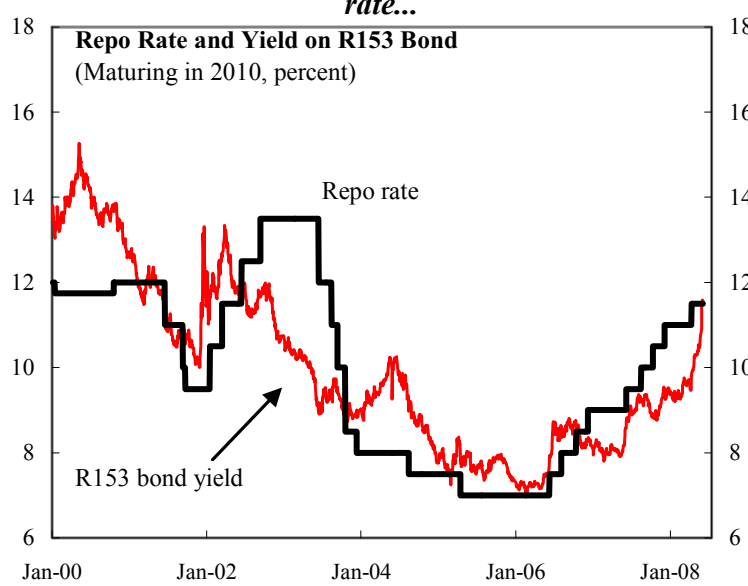

Sources: SARB, BER, Datastream, and IMF.

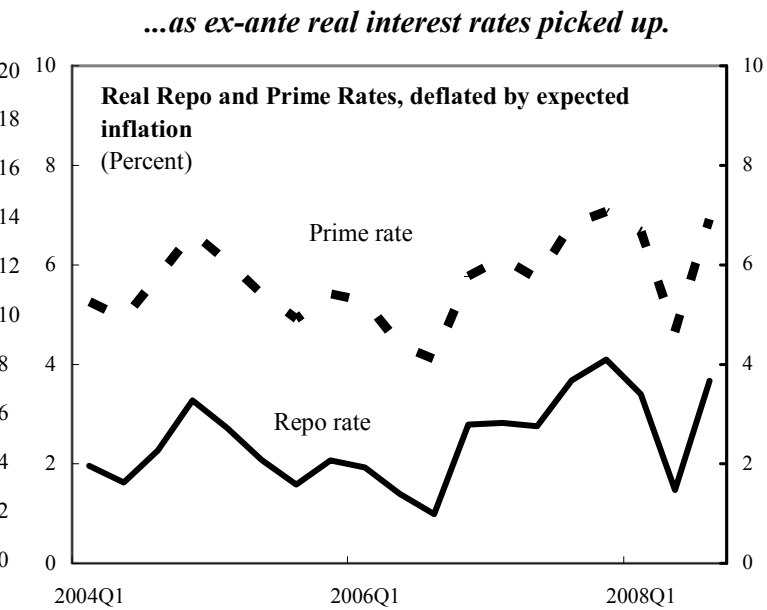

...and so have measures of inflation expectations.

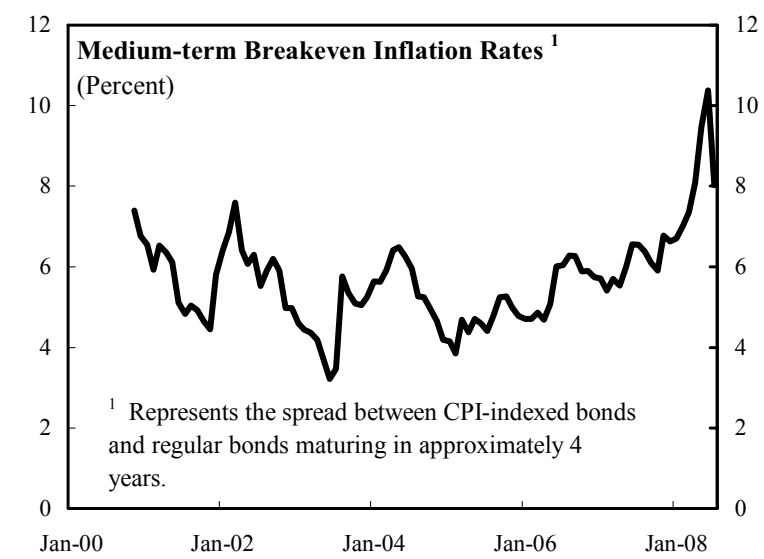

...but forward rates are downplaying the probability of further increases.

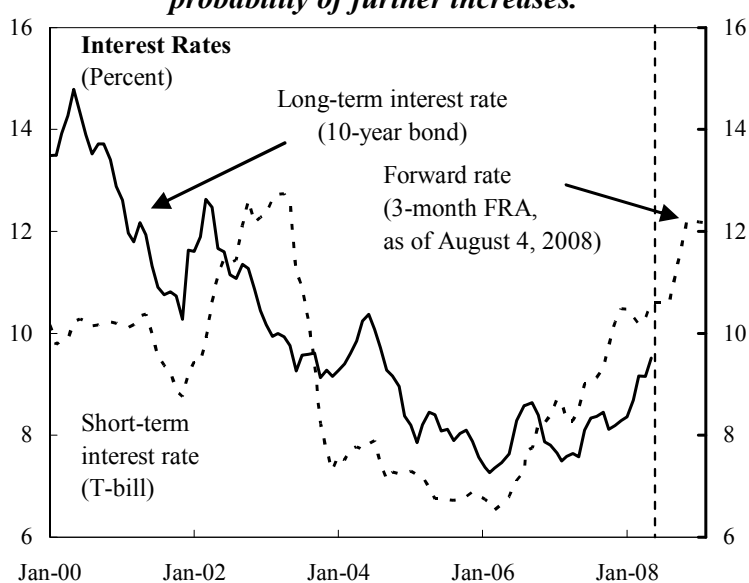


Figure 4. South Africa: Fiscal Developments

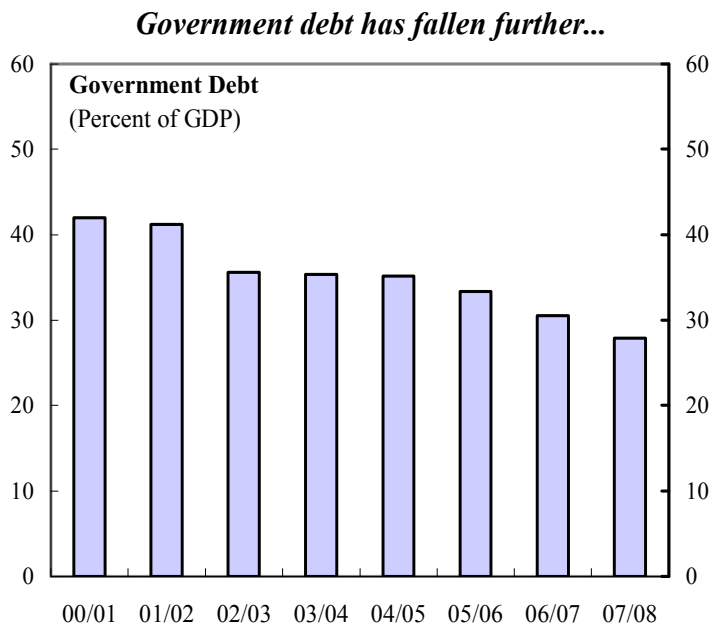

...supported by rising revenues...

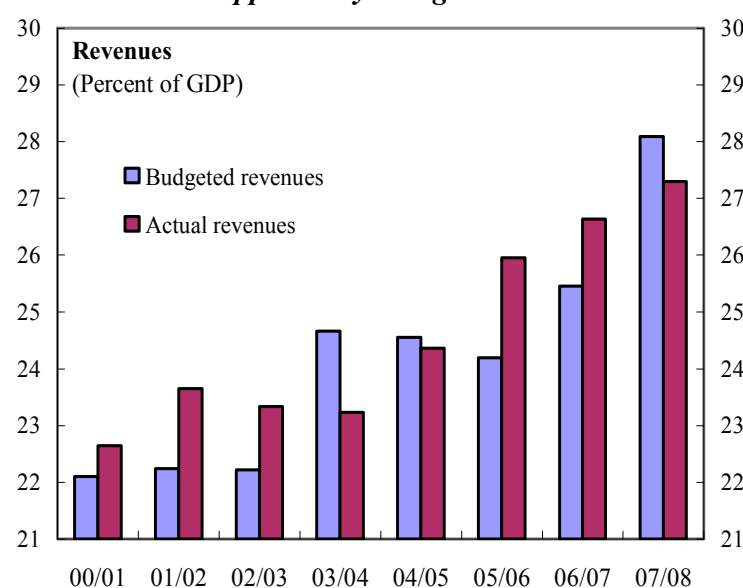

$\begin{array}{llllllll}00 / 01 & 01 / 02 & 02 / 03 & 03 / 04 & 04 / 05 & 05 / 06 & 06 / 07 & 07 / 08\end{array}$

Government expenditures have stabilized...

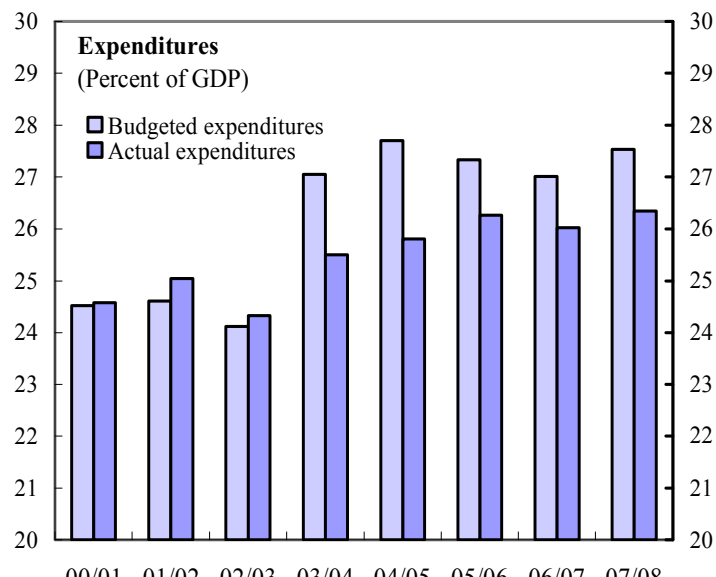

$\begin{array}{llllllll}00 / 01 & 01 / 02 & 02 / 03 & 03 / 04 & 04 / 05 & 05 / 06 & 06 / 07 & 07 / 08\end{array}$ ....as the budget remained in surplus...

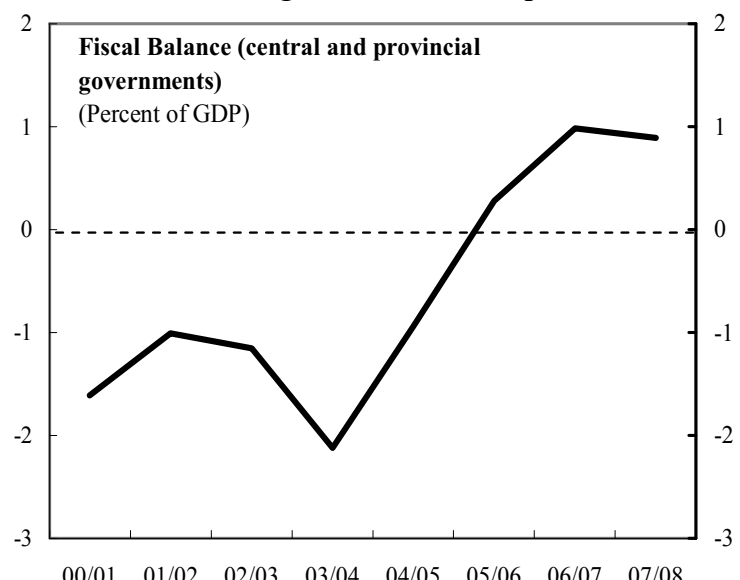

...due largely to buoyant corporate tax receipts.

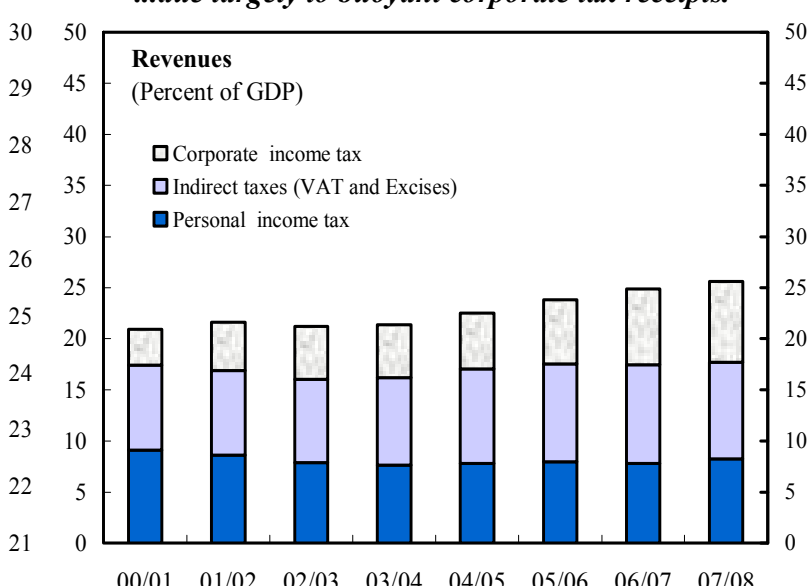

....as have social outlays.

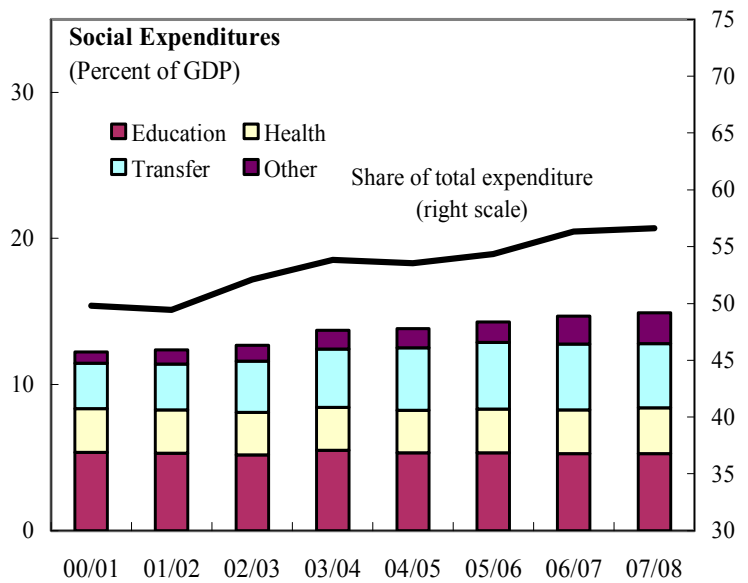

Sources: National Treasury and IMF. 


\section{APPENDIX I. SOUTH AFRICA-DEBT SUSTAINABILITY ANALYSIS}

South Africa's public debt position remains sustainable. The ratio of government debt to GDP continues to fall steeply, from $35 \frac{1}{4}$ percent in 2005 to $281 / 2$ percent at end-2007. Under the policies outlined in the 2008/9 budget and the medium-term expenditure framework, government debt should continue to decline to below 16 percent of GDP over the next five years. Gross financing needs should fall to less than 2 percent of GDP per year in the medium term, significantly below the average of the past five years (Figure 1). Total public debt would fall more gradually, as public enterprise borrowing to finance their investment expansion would add about 51/2 percent of GDP in debt by 2013 (Table 1).

The declining trend in the public debt-to-GDP ratio appears to be broadly robust to a variety of shocks, including weaker GDP growth, a lower primary balance, a 30 percent real depreciation of the exchange rate, and a 10 percent increase in the debt stock (Figure 1). Under most of these scenarios, the government debt ratio is only slightly above the baseline over the projection period, and in the case of the "no policy change" scenario it falls well below. It picks up somewhat, while remaining manageable, in the case of a hypothetical 10 percent contingent liability shock, which is more than the sum of the projected increase in public enterprise debt over the period and the current stock of government financial guarantees (3.4 percent of GDP by February 2008).

South Africa's external debt is projected to rise to about 35 percent of GDP in the medium term. The current account deficit is projected to remain large during the entire projection period. During 2008-09, despite slower domestic demand growth, the current account deficit is projected to widen, reflecting deteriorating terms of trade and the pick up in public investment with a high import content. The deficit will peak at just over $9 \frac{1}{2}$ percent of GDP in 2009 and decline slightly to about 9 percent of GDP by 2013, as import growth subsides. The deficit is envisaged to be financed by a mixture of debt and nondebt creating capital inflows, driving the external debt-to-GDP ratio up to about 35 percent of GDP by 2011 , at which level it would remain in subsequent years.

The outlook for South Africa's external debt deteriorates without becoming overly unfavorable under a broad range of shocks (Figure 2). With rand-denominated debt accounting for 42 percent of external debt at end-2007, currency risk is moderate; the share of short-term debt in foreign-currency denominated debt (421/2 percent at end-2007) implies moderate rollover risk as well. The results of various stress tests indicate that the largest adverse impact on the external debt would arise from a larger than projected current account deficit - a noninterest current account deficit higher by about $1 \frac{1}{2}$ percentage points of GDP on average over the next five years would bring the debt-to-GDP ratio to about 42 percent by end-2013. Permanent adverse shocks to real GDP growth and real interest rates, whether considered individually or together, or a 30 percent one-time real exchange rate depreciation would have only a minor-to-moderate effect. 
Table 1. South Africa: Public Sector Debt Sustainability Framework, 2005-13

(In percent of GDP, unless otherwise indicated)

\begin{tabular}{|c|c|c|c|c|c|c|c|c|c|c|}
\hline & \multicolumn{2}{|c|}{ Actual } & \multirow[b]{2}{*}{2007} & \multicolumn{6}{|c|}{ Projections } & \multirow{3}{*}{$\begin{array}{c}\text { Debt-stabiliz }^{\text {primary }} \\
\text { balance }\end{array}$} \\
\hline & 2005 & 2006 & & 2008 & 2009 & 2010 & 2011 & 2012 & 2013 & \\
\hline & & & & & & & & & & \\
\hline Baseline: Government debt ${ }^{1}$ & 35.3 & 33.1 & 28.6 & 25.6 & 22.8 & 20.7 & 18.8 & 17.2 & 15.7 & -0.3 \\
\hline $\mathrm{o} / \mathrm{w}$ foreign-currency denominated & 4.5 & 4.6 & 3.9 & 4.5 & 4.1 & 3.9 & 3.7 & 3.3 & 3.0 & \\
\hline Change in public sector debt & -1.1 & -2.2 & -4.5 & -3.0 & -2.8 & -2.1 & -1.8 & -1.7 & -1.5 & \\
\hline Identified debt-creating flows $(4+7+12)$ & -2.9 & -4.5 & -5.4 & -4.5 & -3.1 & -2.8 & -2.5 & -2.3 & -2.1 & \\
\hline Primary deficit & -3.2 & -3.8 & -3.7 & -2.8 & -2.0 & -2.1 & -2.0 & -1.9 & -1.7 & \\
\hline Revenue and grants & 27.3 & 28.2 & 28.7 & 28.5 & 28.3 & 28.4 & 28.3 & 28.3 & 28.3 & \\
\hline Primary (noninterest) expenditure & 24.0 & 24.4 & 25.0 & 25.6 & 26.4 & 26.2 & 26.3 & 26.4 & 26.5 & \\
\hline Automatic debt dynamics $^{2}$ & 0.4 & -0.7 & -1.6 & -1.6 & -1.1 & -0.7 & -0.5 & -0.4 & -0.4 & \\
\hline Contribution from interest rate/growth differential ${ }^{3}$ & -0.2 & -1.1 & -1.5 & -1.6 & -1.1 & -0.7 & -0.5 & -0.4 & -0.4 & \\
\hline Of which contribution from real interest rate & 1.5 & 0.6 & -0.1 & -0.7 & -0.2 & 0.2 & 0.4 & 0.4 & 0.4 & \\
\hline Of which contribution from real GDP growth & -1.6 & -1.7 & -1.5 & -0.9 & -0.8 & -0.9 & -0.9 & -0.8 & -0.8 & \\
\hline Contribution from exchange rate depreciation ${ }^{4}$ & 0.5 & 0.4 & -0.1 & & & & & & & \\
\hline Other identified debt-creating flows & 0.0 & 0.0 & -0.1 & 0.0 & 0.0 & 0.0 & 0.0 & 0.0 & 0.0 & \\
\hline Privatization and other extraordinary rece & -0.4 & -0.2 & -0.1 & 0.0 & 0.0 & 0.0 & 0.0 & 0.0 & 0.0 & \\
\hline Recognition of implicit or contingent liabilities & 0.0 & 0.0 & 0.0 & 0.0 & 0.0 & 0.0 & 0.0 & 0.0 & 0.0 & \\
\hline Other & 0.4 & 0.2 & 0.0 & 0.0 & 0.0 & 0.0 & 0.0 & 0.0 & 0.0 & \\
\hline Residual, including asset changes $(2-3)^{5}$ & 1.8 & 2.3 & 0.9 & 1.5 & 0.3 & 0.7 & 0.7 & 0.6 & 0.6 & \\
\hline Public sector debt-to-revenue ratio ${ }^{1}$ & 129.4 & 117.5 & 99.7 & 90.0 & 80.6 & 72.9 & 66.6 & 60.7 & 55.4 & \\
\hline Gross financing need ${ }^{6}$ & 3.5 & 3.5 & 2.8 & 2.3 & 2.9 & 2.2 & 1.8 & 1.6 & 1.3 & \\
\hline in billions of U.S. dollars & 8.5 & 9.1 & 7.8 & 6.9 & 9.6 & 7.9 & 7.1 & 6.6 & 5.7 & \\
\hline Scenario with key variables at their historical averages ${ }^{7}$ & & & & 26.8 & 23.8 & 21.3 & 18.7 & 16.2 & 13.6 & 0.0 \\
\hline Scenario with no policy change (constant primary balance) in $2008-2013$ & & & & 24.8 & 20.3 & 16.8 & 13.3 & 9.9 & 6.6 & -0.1 \\
\hline \multicolumn{11}{|l|}{ Key Macroeconomic and Fiscal Assumptions Underlying Baseline } \\
\hline Real GDP growth (in percent) & 5.0 & 5.4 & 5.1 & 3.8 & 3.7 & 4.4 & 4.8 & 5.0 & 5.0 & \\
\hline Average nominal interest rate on public debt (in percent) ${ }^{8}$ & 9.9 & 9.5 & 9.2 & 9.2 & 9.0 & 8.9 & 8.1 & 7.8 & 7.8 & \\
\hline Average real interest rate (nominal rate minus change in GDP deflator, in percen & 4.7 & 2.3 & 0.2 & -2.3 & -0.7 & 1.5 & 2.6 & 2.9 & 3.0 & \\
\hline Inflation rate (GDP deflator, in percent) & 5.2 & 7.2 & 8.9 & 11.6 & 9.7 & 7.4 & 5.5 & 4.9 & 4.8 & \\
\hline Growth of real primary spending (deflated by GDP deflator, in percent) & 7.8 & 7.0 & 7.8 & 6.4 & 6.7 & 3.9 & 4.9 & 5.6 & 5.5 & \\
\hline Primary deficit & -3.2 & -3.8 & -3.7 & -2.8 & -2.0 & -2.1 & -2.0 & -1.9 & -1.7 & \\
\hline \multicolumn{11}{|l|}{ Memorandum items: } \\
\hline Debt of nonfinancial public enterprises & 5.8 & 5.8 & 5.7 & 7.5 & 8.4 & 8.9 & 10.5 & 10.9 & 11.1 & \\
\hline Debt of local governments and local enterprises & 1.5 & 1.4 & 1.3 & 1.3 & 1.3 & 1.3 & 1.3 & 1.3 & 1.3 & \\
\hline Total public sector debt under the baseline & 42.5 & 40.3 & 35.6 & 34.4 & 32.6 & 30.9 & 30.7 & 29.5 & 28.1 & \\
\hline
\end{tabular}

Total public sector debt under the baseline

Sources: National Treasury and IMF staff estimates.

${ }^{2}$ Derived as $[(r-p(1+g)-g+a e(1+r)](1+g+p+g p))$ times previous period debt ratio, with $r=$ interest rate; $p=$ growth rate of GDP deflator; $g=$ real GDP growth rate; $a=$ share of foreign-currency

denominated debt; and $\mathrm{e}=$ nominal exchange rate depreciation (measured by increase in the local currency value of the U.S. dollar).

The real interest rate contribution is derived from the denominator in footnote 2 as $r-\pi(1+g)$ and the real growth contribution as -g.

The exchange rate contribution is derived from the numerator in footnote 2 as ae(1+r).

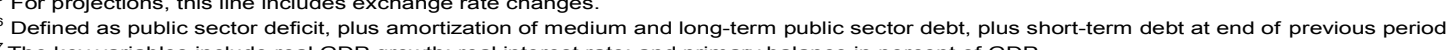

作

${ }^{9}$ Assumes that key variables (real GDP growth, real interest rate, and other identified debt-creating flows) remain at the level of the last projection year 
Figure 1. South Africa: Public Debt Sustainability: Bound Tests ${ }^{1}$ (Public debt in percent of GDP)
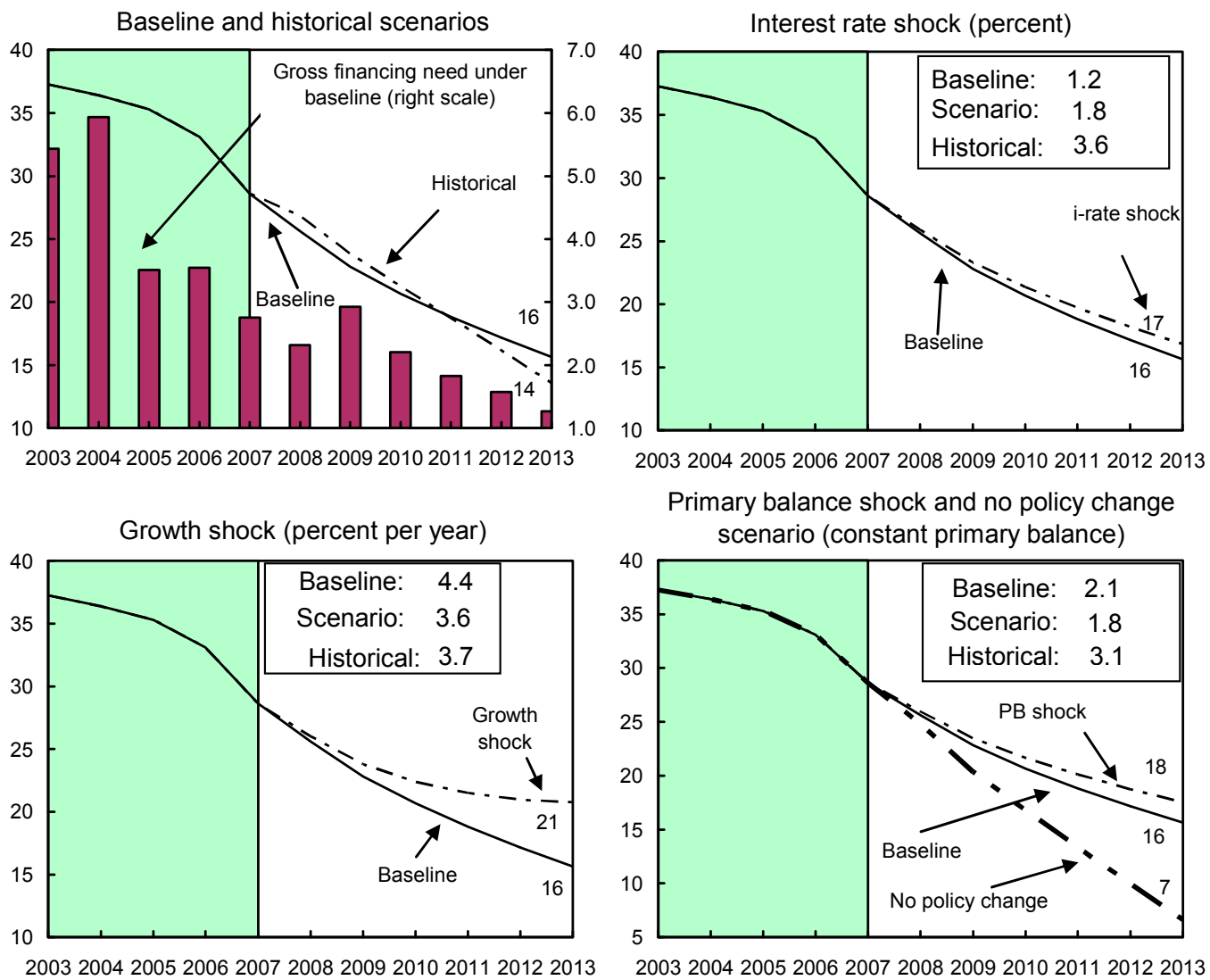

Primary balance shock and no policy change scenario (constant primary balance)

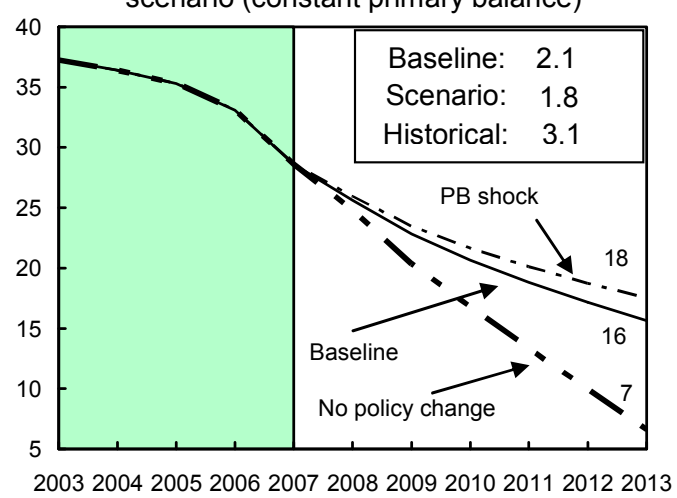

Real depreciation and contingent liabilities
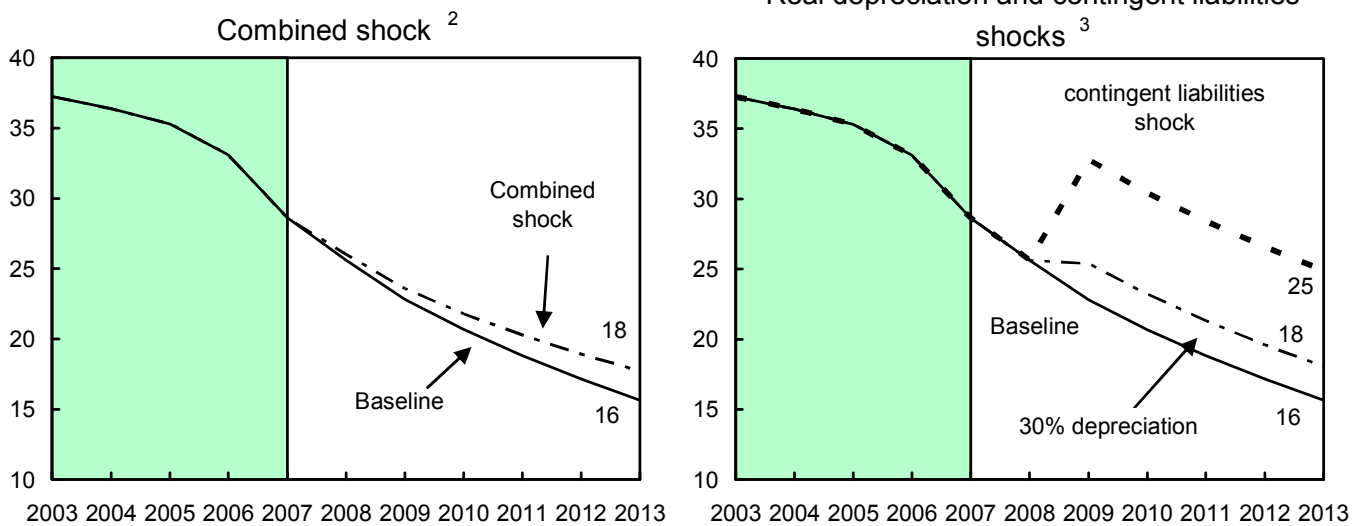

Sources: International Monetary Fund, South African authorities, and IMF staff estimates.

${ }^{1}$ Shaded areas represent actual data. Individual shocks are permanent one-half standard deviation shocks. Figures in the boxes represent average projections for the respective variables in the baseline and scenario being presented. Ten-year historical average for the variable is also shown.

${ }^{2}$ Permanent $1 / 4$ standard deviation shocks applied to real interest rate, growth rate, and primary balance.

${ }^{3}$ One-time real depreciation of 30 percent and 10 percent of GDP shock to contingent liabilities occur in 2009 , with real depreciation defined as nominal depreciation (measured by percentage fall in the dollar value of local currency) minus domestic inflation (based on GDP deflator). 
Table 2. South Africa: External Debt Sustainability Framework, 2005-2013

(In percent of GDP, unless otherwise indicated)

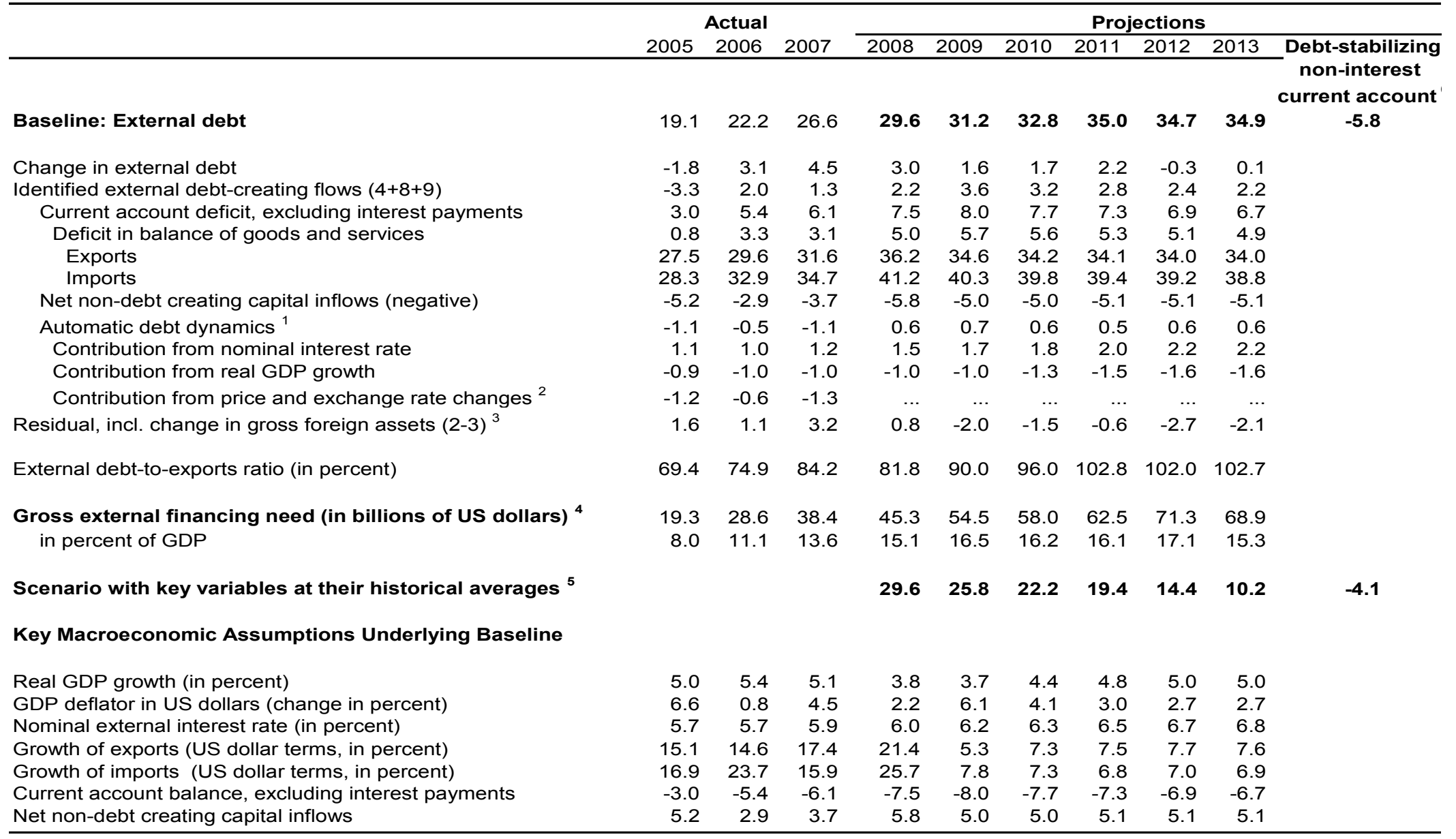

Sources: SARB and IMF staff estimates.

${ }^{1}$ Derived as $[r-g-r(1+g)+e a(1+r)] /(1+g+r+g r)$ times previous period debt stock, with $r=$ nominal effective interest rate on external debt; $r=$ change in domestic GDP deflator in US dollar terms,

$\mathrm{g}=$ real GDP growth rate, $\mathrm{e}=$ nominal appreciation (increase in dollar value of domestic currency), and $\mathrm{a}=$ share of domestic-currency denominated debt in total external debt.

${ }_{2}^{2}$ The contribution from price and exchange rate changes is defined as $[-r(1+g)+e a(1+r)] /(1+g+r+g r)$ times previous period debt stock. $r$ increases with an appreciating domestic currency $(e>0)$ and rising GDP deflator.

${ }^{3}$ For projection, line includes the impact of price and exchange rate changes.

${ }^{4}$ Defined as current account deficit, plus amortization on medium- and long-term debt, plus short-term debt at end of previous period.

${ }^{5}$ The key variables include real GDP growth; nominal interest rate; dollar deflator growth; and both non-interest current account and non-debt inflows in percent of GDP.

${ }^{6}$ Long-run, constant balance that stabilizes the debt ratio assuming that key variables (real GDP growth, nominal interest rate, dollar deflator growth, and non-debt inflows in percent of GDP) remain at their levels

of the last projection year. 
Figure 2. Country: External Debt Sustainability: Bound Tests ${ }^{1}$ (External debt in percent of GDP)
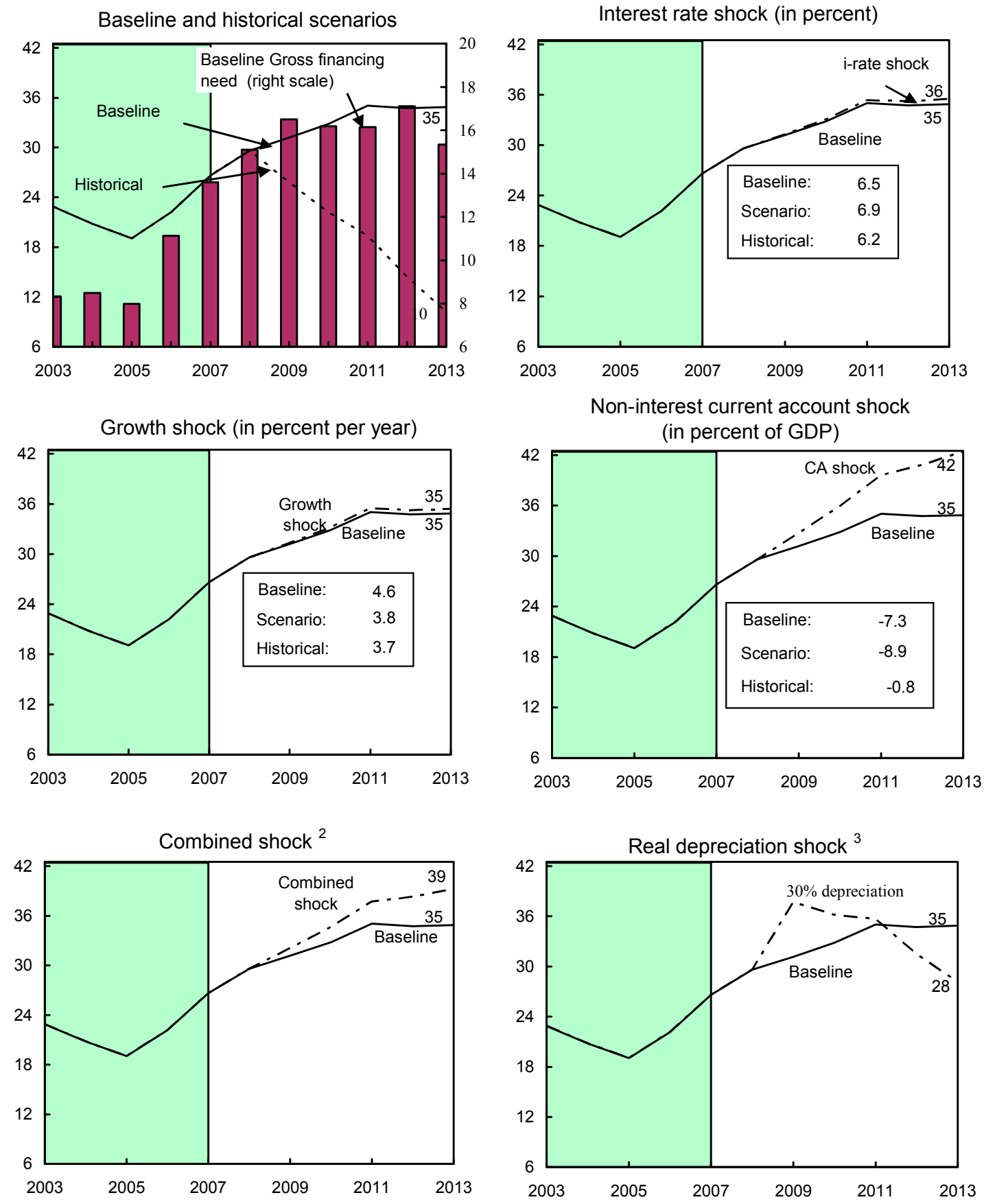

Sources: International Monetary Fund and IMF staff estimates.

${ }^{1}$ Shaded areas represent actual data. Individual shocks are permanent one-half standard deviation shocks. Figures in the boxes represent average projections for the respective variables in the baseline and scenario being presented. Ten-year historical average for the variable is also shown.

${ }^{2}$ Permanent $1 / 4$ standard deviation shocks applied to real interest rate, growth rate, and current account balance.

${ }^{3}$ One-time real depreciation of 30 percent occurs in 2009. 
INTERNATIONAL MONETARY FUND

SOUTH AFRICA

Staff Report for the 2008 Article IV Consultation-Informational Annex

Prepared by Staff Representatives for the 2008 Consultation with South Africa

Approved by Saul Lizondo and Adnan Mazarei

August 15, 2008

- $\quad$ Relations with the Fund. Describes financial and technical assistance by the IMF and provides information on the safeguards assessment and exchange system. South Africa has no outstanding purchases and loans from the Fund.

- $\quad$ The JMAP Bank-Fund Matrix. Describes the priorities and main activities of the World Bank Group and the IMF and areas of cooperation in their work with the South African authorities.

- Statistical Issues. Assesses the quality of statistical data. Economic data for South Africa are generally of good quality and are provided to the Fund and the public in a timely manner. South Africa subscribes to the SDDS and publishes all data on the reserves template.

Contents

Page

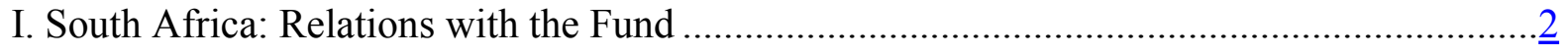

II. South Africa: the JMAP Bank-Fund Matrix …......................................................

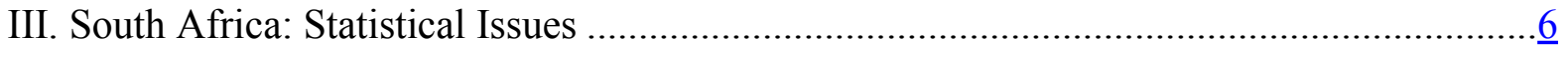




\section{SOUTH AFRICA: Relations WITH THE FUND}

(As of June 30, 2008)

I. Membership Status: Joined 12/27/1945; Accepted the obligations of Article VIII, Sections 2,3, and 4 of the Fund's Articles of Agreement on September 15, 1973.

II. General Resources Account:

Quota

Fund holdings of currency

Reserve position in Fund

III. SDR Department:

Net cumulative allocation

Holdings $\underline{\text { SDR Million }}$

$1,868.50$

$1,867.20$

1.30

$\underline{\text { SDR Million }}$

220.36

223.07

None

IV. Outstanding Purchases and Loans:

V. Latest Financial Arrangements:
Percent Quota

100.00

99.93

0.07

\section{Percent Allocation \\ 100.00 \\ 101.23}

VI. Projected Payments to Fund (SDR Million; based on existing use of resources and present holdings of SDRs):

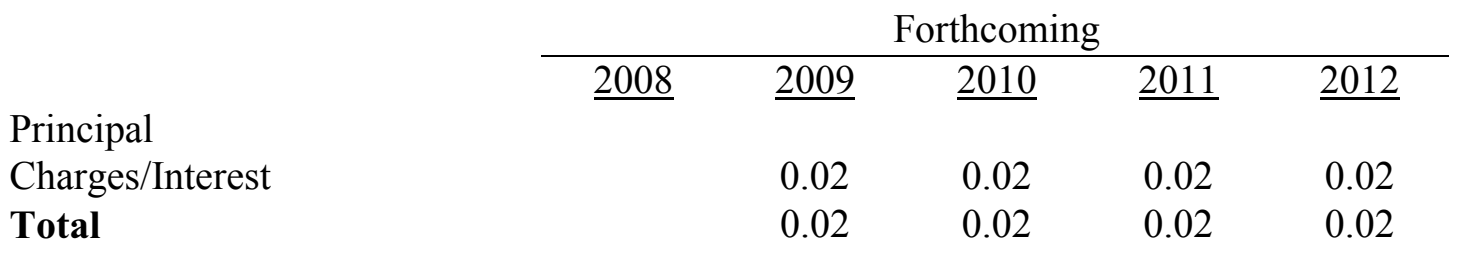

\section{Exchange Rate Arrangement:}

The South African rand floats against other currencies. South Africa maintains an exchange system free of restrictions on the making of payments and transfers for current international transactions, except for measures implemented solely for the preservation of national or international security which South Africa is in the process of notifying the Fund about pursuant to the procedures set out in Decision No. 144-(52/51) (August 14, 1952). On May 20, 2008 the exchange rate of the rand was US\$0.1318=R1.

With the abolition of the financial rand in 1995, all exchange controls on nonresidents were eliminated. They are free to purchase shares, bonds, and other assets without restriction and to repatriate dividends, interest receipts, and current and capital profits, as well as the original investment capital. Foreign companies, governments and institutions may list on South Africa's bond and securities exchanges. 
Since 1995, exchange controls on capital transaction by residents have also been relaxed. Rather than completely liberalizing particular types of current or capital transactions, the authorities have pursued a strategy of allowing an increasing array of transactions, with each subject to a quantitative cap that has been progressively raised over time. Regarding outward foreign direct investment by South African corporates, application to the South African Reserve Bank's Exchange Control Department is still required for transactions above $\mathrm{R} 50$ million a year, for monitoring purposes and approval in terms of existing foreign direct investment criteria, including demonstrated benefit to South Africa. The South African Reserve Bank (SARB) reserves the right to stagger capital outflows relating to large foreign direct investments so as to manage any potential impact on the foreign exchange market.

In 2008, the authorities initiated a process of replacing direct exchange controls on local institutional investors with prudential regulations and relaxing their foreign exposure limits. Under the new system, the SARB will monitor these investors' foreign exposure through quarterly reports, abolishing the existing pre-transaction authorization requests; however, substantial changes in foreign exposure will still require pre-notification. Institutional investors are permitted to invest in foreign securities, subject to an overall limit of 20 percent of their total retail assets for retirement funds and long-term insurers. Investment managers registered as institutional investors for exchange control purposes and collective investment schemes management companies are restricted to 30 percent of total retail assets under management. There is an additional allowance of 5 percent of assets for portfolio investment in Africa for all institutional investors. Banks' foreign exposure limit (which remains to be precisely defined) will be raised to 40 percent of liabilities from 40 percent of capital. Corporates are not allowed portfolio investment at present. They may, upon application, be permitted to establish primary listings at stock exchanges offshore under certain conditions. Their currency proceeds from exports must be repatriated within 180 days from accrual. All local entities are now allowed to participate in the rand futures market, enabling them to hedge and diversify their portfolios.

Private individuals are allowed to invest up to $\mathrm{R} 2$ million offshore. In addition to the above, they can take out further R 500,000 a year in documented discretionary allowance (gifts, donations, travel, etc.). There are restrictions on the transfer of funds abroad by emigrants ("blocked funds"). The transfer of blocked funds in excess of R 2 million for individuals and $\mathrm{R} 4$ million for families is allowed, provided a 10 percent exit levy is paid. Large amounts may be staggered to manage any impact on the foreign exchange market. Dividends and interest payments on the blocked funds are freely transferable abroad.

\section{Article IV Consultations}

The 2008 Article IV consultation was concluded by the Executive Board on September 8, 2008. South Africa is on the standard 12-month Article IV consultation cycle.

\section{Technical Assistance}


A FAD mission took place in 2003 to discuss with the National Treasury their draft royalty bill. A monetary and financial statistics mission took place in 2003 , followed up by a visit during May-June, 2004.

A STA mission, supported by a labor statistics consultant funded by the World Bank, undertook a review of South Africa Labor Force Statistics in March 2005. The mission recommended steps to produce statistics that are more reliable, better quality, and more closely aligned with International Labor Organization (ILO) standards.

A number of LEG missions in 2007-08 assisted the authorities in the ongoing process of rewriting the Income Tax Act and drafting a new Tax Administration Act. 


\section{SOUTH AFrICA: THE JMAP BANK-FUND MATRIX}

\begin{tabular}{|c|c|c|c|}
\hline Title & Products & $\begin{array}{c}\text { Provisional } \\
\text { timing of } \\
\text { missions }\end{array}$ & $\begin{array}{c}\text { Expected } \\
\text { delivery date }\end{array}$ \\
\hline \multicolumn{4}{|c|}{ A. Mutual information on relevant work programs } \\
\hline $\begin{array}{l}\text { The World } \\
\text { Bank work } \\
\text { program in } \\
\text { the next } \\
12 \text { months }\end{array}$ & $\begin{array}{l}\text { Analytical work on Labor Markets } \\
\text { Analysis of Binding Constraints on Skill Development } \\
\text { Study of Public Expenditure on Education } \\
\text { Second Investment Climate Assessment (and related } \\
\text { background studies) } \\
\text { Land reform policy support } \\
\text { Energy sector dialogue } \\
\text { Technical assistance to the National Treasury in developing } \\
\text { and maintaining a computable general equilibrium model }\end{array}$ & & $\begin{array}{l}\text { June } 2009 \\
\text { July } 2009 \\
\text { Q2 } 2009 \\
\text { S1 } 2009 \\
\text { Ongoing } \\
\text { Ongoing }\end{array}$ \\
\hline $\begin{array}{l}\text { The Fund } \\
\text { work } \\
\text { program in } \\
\text { the next } 12 \\
\text { months }\end{array}$ & $\begin{array}{l}\text { 1. } 2008 \text { Article IV consultation and FSSA report } \\
\text { - Background papers on a) growth constraints and aggregate } \\
\text { savings behavior in SA, b) handling relative price shocks } \\
\text { within the inflation targeting framework, and c) the scope for } \\
\text { fiscal reforms to influence growth and employment. } \\
\text { 2. Staff visit - preparatory work for the } 2009 \text { Article IV } \\
\text { consultation } \\
\text { 3. } 2009 \text { Article IV consultation } \\
\text { 4. LEG TA in rewriting the Income Tax Act and drafting a } \\
\text { new Tax Administration Act }\end{array}$ & $\begin{array}{l}\text { May-June } \\
2008 \\
\text { Q4 } 2008 \\
\text { Q3 } 2009\end{array}$ & $\begin{array}{l}\text { Board meeting } \\
\text { in September } \\
2008 \\
\text { Board meeting } \\
\text { in Q3-Q4 2009 } \\
\text { Ongoing }\end{array}$ \\
\hline Title & Products & $\begin{array}{c}\text { Provisional } \\
\text { timing of } \\
\text { missions }\end{array}$ & $\begin{array}{c}\text { Expected } \\
\text { delivery date }\end{array}$ \\
\hline \multicolumn{4}{|c|}{ B. Requests for work program inputs } \\
\hline $\begin{array}{l}\text { Fund } \\
\text { request to } \\
\text { Bank }\end{array}$ & Periodic update on progress on analytical work & & \\
\hline $\begin{array}{l}\text { Bank } \\
\text { request to } \\
\text { Fund }\end{array}$ & $\begin{array}{l}\text { Periodic updates on macroeconomic developments and } \\
\text { analytical work }\end{array}$ & & \\
\hline
\end{tabular}




\section{SOUTH Africa: Statistical ISSUES}

Data provided to the Fund are adequate for surveillance purposes. South Africa subscribed to the Special Data Dissemination Standard (SDDS) on August 2, 1996 and is in observance of specifications for coverage, periodicity, and timeliness of data, although using a flexibility option on the timeliness and periodicity of unemployment data. A Report on Observance of Standards and Codes - Data Module, Response by the Authorities, and Detailed Assessments Using the Data Quality Assessment Framework (DQAF) was published on October 16, 2001.

\section{Real sector}

The national accounts are compiled according to the $S N A$ 1993. In November 2004, the base year of the national accounts was changed from 1995 to 2000 . At the same time, benchmarking was undertaken to reflect more accurately the structure of the economy and to introduce other methodological changes to the compilation of data. These changes resulted in an upward revision of the average annual growth rate of real GDP for the period 1998 to 2003 from 2.4 percent to 2.7 percent. Reporting of real sector data for International Financial Statistics (IFS) is timely.

Labor market statistics are published with lags of three months. Given the seriousness of the unemployment problem, labor market analysis and policy design would benefit from better, more frequent and timely labor market data. A new quarterly Labor Force Survey has been introduced; results for the first and second quarters of 2008 have been published in August 2008 .

The consumer price index (CPI) covers all households living in metropolitan and urban areas, which represent approximately 56 percent of the total number of households and 75 percent of private consumption expenditures. The CPI weights are based on an Income and Expenditure of Households Survey conducted from November 1999 to October 2000. Beginning with the April 2003 index, Statistics South Africa issued revisions to the Consumer Price Index for the period January 2002 to March 2003, reflecting the incorporation of more reliable data on residential rents. After finalizing the ongoing analysis of the 2005 Income and Expenditure Survey, Statistics South Africa plans to update the weights in the CPI basket in January 2009. At the same time, Statistics South Africa will change the way of measuring housing costs. The concept of owners' equivalent rent will be used to more accurately reflect the cost of the accommodation services derived by owner occupiers from their own homes.

\section{Government finance}

Data are compiled and disseminated according to the GFSM 2001 framework. Data for social security funds and central government's extra budgetary funds have been reported on an accrual basis, starting in 2000 and 2002, respectively. Starting in 2005, the authorities have included additional noncash data, consistent with their migration to accrual accounting. 
South Africa currently reports data for the consolidated general government for publication in the Government Finance Statistics Yearbook. It also reports monthly data covering the cash operations of the budgetary central government for publication in IFS.

\section{Monetary statistics}

Monetary statistics compiled by SARB are consistent with the methodology recommended in the Monetary and Financial Statistics Manual. South Africa regularly reports good quality monetary statistics for publication in the IFS and the IFS Supplement, although there is room for improving the timeliness of the data on non-depository financial institutions.

\section{Balance of payments}

Balance of payments data are broadly consistent with the fifth edition of the Balance of Payments Manual (BPM5). The authorities are also working with their partners in the Southern African Customs Union (SACU) to improve the coverage of intra-SACU trade flows. Data reported for Direction of Trade Statistics differ substantially from external trade data reported for IFS, particularly exports, due to balance of payments adjustments.

The banking sector holdings of foreign-currency assets have been removed from the official measure of reserves, in accordance with international practice. Data on international reserves position are disseminated in line with the requirements of the IMF's template on international reserves and foreign currency liquidity.

Net errors and omissions in the balance of payments are large, averaging 2 percent of GDP during 2003-07. Work is ongoing to improve the reliability and accuracy of balance of payments data. 


\section{SOUTH AFRICA: TABLE OF COMMON INDICATORS REQUIRED FOR SURVEILLANCE}

(as of July 31,2008 )

\begin{tabular}{|c|c|c|c|c|c|c|c|}
\hline & \multirow{2}{*}{$\begin{array}{c}\text { Date of } \\
\text { latest } \\
\text { observatio } \\
n\end{array}$} & \multirow{2}{*}{$\begin{array}{l}\text { Date } \\
\text { received }\end{array}$} & \multirow{2}{*}{$\begin{array}{l}\text { Frequency } \\
\text { of } \\
\text { Data }^{7}\end{array}$} & \multirow{2}{*}{$\begin{array}{l}\text { Frequency } \\
\text { of } \\
\text { Reporting }\end{array}$} & \multirow{2}{*}{$\begin{array}{l}\text { Frequency } \\
\text { of } \\
\text { publication } \\
7\end{array}$} & \multicolumn{2}{|c|}{ Memo Items: } \\
\hline & & & & & & $\begin{array}{l}\text { Data Quality - } \\
\text { Methodological } \\
\text { soundness }^{8}\end{array}$ & $\begin{array}{l}\text { Data Quality - } \\
\text { Accuracy and } \\
\text { reliability }\end{array}$ \\
\hline Exchange Rates & $7 / 21 / 08$ & $7 / 21 / 08$ & $\mathrm{D}$ & D & $\mathrm{D}$ & & \\
\hline $\begin{array}{l}\text { International Reserve Assets and } \\
\text { Reserve Liabilities of the } \\
\text { Monetary Authorities }\end{array}$ & $6 / 08$ & $6 / 10 / 08$ & M & M & M & & \\
\hline Reserve/Base Money & $6 / 08$ & $7 / 31 / 08$ & M & M & M & \multirow{4}{*}{$\mathrm{O}, \mathrm{O}, \mathrm{LO}, \mathrm{O}$} & \multirow{4}{*}{ LO, O, O, O } \\
\hline Broad Money & $5 / 08$ & $6 / 30 / 08$ & M & M & M & & \\
\hline Central Bank Balance Sheet & $5 / 08$ & $7 / 31 / 08$ & M & M & M & & \\
\hline $\begin{array}{l}\text { Consolidated Balance Sheet of } \\
\text { the Banking System }\end{array}$ & $5 / 08$ & 6/30/08 & M & M & M & & \\
\hline Interest Rates ${ }^{2}$ & $7 / 21 / 08$ & $7 / 21 / 08$ & $\mathrm{D}$ & $\mathrm{D}$ & $\mathrm{D}$ & & \\
\hline Consumer Price Index & $5 / 08$ & $6 / 28 / 08$ & M & M & M & O, LO, O, O & LO, LO, O, O \\
\hline $\begin{array}{l}\text { Revenue, Expenditure, Balance } \\
\text { and Composition of Financing }{ }^{3}- \\
\text { General Government }\end{array}$ & FY 2007/8 & $4 / 30 / 08$ & A & $s$ & $\mathrm{~s}$ & \multirow{2}{*}{$\mathrm{O}, \mathrm{O}, \mathrm{O}, \mathrm{O}$} & \multirow{2}{*}{$\mathrm{O}, \mathrm{O}, \mathrm{O}, \mathrm{O}$} \\
\hline $\begin{array}{l}\text { Revenue, Expenditure, Balance } \\
\text { and Composition of Financing }{ }^{3}- \\
\text { Central Government }\end{array}$ & $05 / 08$ & $6 / 30 / 08$ & M & Q & $Q$ & & \\
\hline $\begin{array}{l}\text { Stocks of Central Government } \\
\text { and Central Government- } \\
\text { Guaranteed Debt }{ }^{5}\end{array}$ & Q1 2008 & $5 / 13 / 08$ & Q & Q & Q & & \\
\hline $\begin{array}{l}\text { External Current Account } \\
\text { Balance }\end{array}$ & Q1 2008 & $5 / 13 / 08$ & Q & Q & $\mathrm{Q}$ & \multirow[t]{2}{*}{ LO, LO, LO, LO } & \multirow[t]{2}{*}{ LO, LO, LO, LO } \\
\hline $\begin{array}{l}\text { Exports and Imports of Goods } \\
\text { and Services }{ }^{6}\end{array}$ & $5 / 08$ & 6/30/08 & M & M & M & & \\
\hline GDP/GNP & Q1 2008 & 5/13/08 & $Q$ & Q & $Q$ & O, LO, LO, LO & LO, O, O, O \\
\hline Gross External Debt & Q1 2008 & 5/13/08 & Q & Q & $Q$ & & \\
\hline International Investment Position & 2006 & $12 / 07$ & A & A & A & & \\
\hline
\end{tabular}

${ }^{1}$ Includes reserve assets pledged or otherwise encumbered as well as net derivative positions.

${ }^{2}$ Both market-based and officially-determined, including discount rates, money market rates, rates on treasury bills, notes and bonds.

${ }^{3}$ Foreign, domestic bank, and domestic nonbank financing.

${ }^{4}$ The general government consists of the central government (budgetary funds, extra budgetary funds, and social security funds) and state and local governments.

${ }^{5}$ Including currency and maturity composition.

${ }^{6}$ Monthly data for goods. Goods and services are published quarterly on the same schedule as the rest of the balance of payments.

${ }^{7}$ Daily (D), Weekly (W), Monthly (M), Quarterly (Q), Annually (A), Irregular (I); Not Available (NA).

${ }^{8}$ Reflects the assessment provided in the data ROSC (October 2001) for the dataset corresponding to the variable in each row. The assessment indicates whether international standards concerning concepts and definitions, scope, classification/sectorization, and basis for recording are fully observed (O), largely observed (LO), largely not observed (LNO), or not observed (NO).

${ }^{9}$ Same as footnote 8, except referring to international standards concerning (respectively) source data, statistical techniques, assessment and validation, and revision studies. 


\section{Statement by the IMF Staff Representative \\ September 8, 2008}

1. This statement summarizes economic developments since the issuance of the staff report. These developments do not alter the thrust of the staff appraisal.

2. In July, annual CPIX inflation reached 13 percent, up from 11.6 percent in June, reflecting a jump in gasoline and electricity prices. Inflation excluding food and energy prices rose slightly to 6.2 percent. Producer prices increased by 18.9 percent relative to July 2007.

3. GDP growth in Q2 was somewhat stronger than consensus at 4.5 percent year-onyear, lifted by good performance in agriculture, nonresidential construction, and manufacturing. Output in the mining sector remained about 5 percent below its level a year ago, despite some recovery from an electricity-shortage-induced slump in Q1. As highfrequency indicators point to a slowdown in interest-sensitive industries, staff's projection of annual GDP growth in 2008 remains unchanged at 3.8 percent.

4. The current account deficit in Q2 narrowed to 7.3 percent of GDP on an annualized basis from 8.9 percent in Q1 on the strength of merchandise exports. It was financed mainly by net portfolio investment which had been negative the previous quarter. Monthly trade data indicate that imports rose sharply in July.

5. The Monetary Policy Committee (MPC) of the South African Reserve Bank kept the policy interest rate on hold at 12 percent at its meeting in August. The Committee noted the decline in international oil prices and domestic agricultural producer prices, as well as the drop in inflation expectations as measured by the break-even inflation rates derived from the bond market, reflecting the expected technical effect of reweighing and rebasing the inflation index in January 2009. The Committee nevertheless observed that significant risks to the inflation outlook remained. 


\section{INTERNATIONAL MONETARY FUND}

EXTERNAL

Public Information Notice

Public Information Notice (PIN) No. 08/137

FOR IMMEDIATE RELEASE

October 22, 2008
International Monetary Fund

$70019^{\text {th }}$ Street, NW

Washington, D. C. 20431 USA

\section{IMF Executive Board Concludes Article IV Consultation with South Africa}

On September 8, 2008 the Executive Board of the International Monetary Fund (IMF) concluded the Article IV consultation with South Africa. ${ }^{1}$

\section{Background}

South Africa's economic performance has strengthened in the last several years, with real GDP growing by 5-51/2 percent in 2005-07, inflation declining to mid-single digits until recently and employment growing steadily. Growth last year was driven by strong domestic demand, with private consumption and investment spending supported by robust consumer and business sentiment. Household consumption was also boosted by growing disposable income, rising employment, and wealth effects from rising asset prices until late in the year. Total employment grew by 3.4 percent in the year to September 2007 and the unemployment rate declined to 23 percent.

However, 2008 saw a slowdown in activity reflecting the cumulative impact of electricity power shortages, the global slowdown, and past monetary tightening. Real GDP growth slowed to 4.2 percent (year-on-year) in the first half of 2008, and subsequent highfrequency indicators point to further moderation.

Inflation pressures have intensified further. Twelve-month CPIX inflation has been rising since early 2007-reaching 13 percent in July 2008, well above the South African Reserve Bank's (SARB) 3-6 percent target range-mainly reflecting rising global food

\footnotetext{
${ }^{1}$ Under Article IV of the IMF's Articles of Agreement, the IMF holds bilateral discussions with members, usually every year. A staff team visits the country, collects economic and financial information, and discusses with officials the country's economic developments and policies. On return to headquarters, the staff prepares a report, which forms the basis for discussion by the Executive Board. At the conclusion of the discussion, the Managing Director, as Chairman of the Board, summarizes the views of Executive Directors, and this summary is transmitted to the country's authorities.
} 
and fuel prices and, until recently, demand pressures. ${ }^{2}$ Inflation expectations for the year ahead have picked up markedly. In response to the deteriorating inflation outlook, the SARB has raised its policy interest rate by 300 basis points since June 2007, to 12 percent by June 2008, but decided to keep it on hold in August in light of falling commodity prices and some moderation in inflation expectations.

Credit to the private sector has begun to moderate but still remains resilient, expanding by 20.3 percent in the year ending in June 2008. Household debt rose slightly to a record level of $781 / 4$ percent of disposable income by the first quarter of 2008 . Pushed mainly by rising interest rates, household debt service has risen to about $11 \frac{1}{4}$ percent of disposable income, but remains below historic highs.

Asset prices continued to rise rapidly in 2007 but has moderated significantly since then. Strong commodity prices drove the JSE all-share index up by 16 percent in 2007. In 2008 the index fell by 4 percent through July, reflecting weakness in financial and manufacturing share prices, which were only partially offset by the strong performance of resource equities. Residential property prices recently slowed considerably, growing by about 4 percent in the year ending in June 2008 .

The current account deficit expanded sharply to 71/4 percent of GDP in 2007 and almost 9 percent in the first quarter of 2008, driven by strong public and private investment and rising international oil prices, before narrowing somewhat to $7 \frac{1}{4}$ percent of GDP in the second quarter of 2008 . The deficit was financed by a mixture of equity and debtcreating inflows, bringing external debt to $261 / 2$ percent of GDP by end-2007. Net portfolio flows were negative in the first quarter of 2008 and the current account deficit was covered by the proceeds from a large foreign direct investment (FDI) deal and an increase in nonresident bank deposits; net portfolio inflows turned positive again in the second quarter. Risk premia on South African debt in international markets rose steeply in the first quarter of 2008, reflecting turmoil in global financial markets, before moderating somewhat by mid-year.

The SARB has maintained a flexible exchange rate system, with a publicly-announced policy of purchasing foreign exchange on the market only to bolster its reserve position. Consistent with this policy, gross reserves grew to US $\$ 34.9$ billion by June 2008- well over 200 percent of short-term external debt. After depreciating markedly in early 2008 , the rand strengthened somewhat by end-July 2008. In real effective terms, the rand has depreciated by 10 percent in the 12 months ending April 2008.

The fiscal balance of the national government turned into a surplus of 0.9 percent of GDP in FY2007/08, bringing government debt down to about 28 percent of GDP. The surplus, the second in a row, reflected a large increase in tax revenue, owing to strong economic activity over most of the period and continued collection efforts. Total public debt, including obligations of public enterprises and local governments, fell to about 35 percent of GDP.

\footnotetext{
${ }^{2}$ The CPIX - the measure targeted by the SARB — excludes interest payments on mortgage loans.
} 


\section{Executive Board Assessment}

Executive Directors welcomed the significant economic strides made by South Africa over the past several years, reflected in high economic growth, low inflation, and rising employment. These achievements have been based on sound macroeconomic policies and a transparent policy framework. South Africa's economic fundamentals remain strong, the external debt is low, and the financial system is resilient.

Recent developments, however, have heightened economic vulnerabilities and made more challenging the achievement of the authorities' medium-term growth strategy. In particular, global food and fuel price shocks have boosted inflation and the external current account deficit, while economic growth has slowed in the context of still-high levels of unemployment and inequality. On the domestic side, an elevated household debt and debt service burden poses further risks to growth and possibly to pockets of the financial system. The deterioration of the economic outlook has heightened the risk of a slowdown of capital inflows. Directors accordingly underlined the importance of continuing to address the constraints to economic growth and job creation, while taking steps to preserve macroeconomic stability and strengthen economic resilience. This will require redoubled efforts to raise South Africa's national saving rate, improve infrastructure, and implement further structural reforms.

Directors welcomed the authorities' pursuit of a prudent fiscal policy, and their intention to maintain a broadly neutral fiscal stance in 2008 while strengthening the social safety net in response to the increase in food prices. Directors acknowledged South Africa's pressing infrastructure and social spending needs, and noted the authorities' plan to raise public investment significantly. Given the importance of sustaining investor confidence and the limited scope for raising private saving, most Directors called for an increase in public saving so as to bring the structural public sector borrowing requirement to zero over the next few years. This should be achieved mainly by containing current expenditure and increasing spending efficiency. Several Directors suggested that the authorities explore options for addressing infrastructure and social needs that would avoid weakening fiscal policy-for example, by relying more widely on public-private partnerships established within an appropriate transparent regulatory regime.

Directors considered that the inflation targeting framework has served South Africa well. They supported the tightening of monetary policy so far in 2008 to contain inflation expectations and the second-round effects of the food and fuel price shocks. They noted the central bank's current pause in further tightening, but considered that the authorities should stand ready to raise interest rates further if supply shocks resume or domestic demand pressures do not dampen as expected. Some Directors considered that conditions warrant the resumption of monetary tightening. Directors also considered the effective lengthening of the policy horizon for bringing inflation back within target range to be appropriate, given the increase in inflationary pressures. They commended the high quality of the central bank's written communications and public discussions, and underscored the continued importance of a clear communication strategy for containing inflation expectations. 
Directors considered that South Africa's floating exchange rate has served as a useful buffer against external shocks, limiting foreign exchange exposure in balance sheets and discouraging speculative inflows. While acknowledging the considerable uncertainty surrounding estimates of the equilibrium value of the currency, Directors took note of the staff's tentative assessment that the currency may be moderately overvalued. Directors supported the authorities' policy of gradually building up international reserves.

Directors welcomed the Financial Sector Assessment Program (FSAP) update finding that South Africa's financial system is sound, well capitalized, and well regulated. They stressed the importance of the authorities' continued proactive engagement with banks to ensure that capital and liquidity buffers are adequate-especially in the current context of a less benign environment, including high exposure to the household sector. Directors called for prompt implementation of the FSAP update recommendations-in particular, those relating to deeper forward-looking financial stability analysis based on bank-level data, and to an improved regulatory framework based on consolidation of the supervision of financial conglomerates and strengthened insurance and pension supervision.

Directors stressed the importance of structural reforms to boost productivity and employment growth. Possible fiscal reforms to be explored include deficit-neutral modifications to revenue and expenditure policies aimed at strengthening incentives to invest and work. Directors also encouraged the authorities to persevere with steps to open the economy to greater international competition, strengthen product and labor market competition, and improve education outcomes.

Public Information Notices (PINs) form part of the IMF's efforts to promote transparency of the IMF's views and analysis of economic developments and policies. With the consent of the country (or countries) concerned, PINs are issued after Executive Board discussions of Article IV consultations with member countries, of its surveillance of developments at the regional level, of post-program monitoring, and of ex post assessments of member countries with longer-term program engagements. PINs are also issued after Executive Board discussions of general policy matters, unless otherwise decided by the Executive Board in a particular case. The staff report (use the free Adobe Acrobat Reader to view this pdf file) for the 2008 Article IV Consultation with South Africa is also available. 
South Africa: Selected Economic Indicators, 2004-08

(Annual percent change, unless otherwise indicated)

\begin{tabular}{|c|c|c|c|c|c|}
\hline & 2004 & 2005 & 2006 & 2007 & $\begin{array}{r}2008 \\
\text { Proj. }\end{array}$ \\
\hline Real GDP & 4.9 & 5.0 & 5.4 & 5.1 & 3.8 \\
\hline CPI (metropolitan areas, annual average) & 1.4 & 3.4 & 4.7 & 7.1 & 11.3 \\
\hline CPIX ${ }^{1,2}$ & 4.3 & 4.0 & 5.0 & 8.6 & 11.6 \\
\hline Broad money $^{2}$ & 13.1 & 20.5 & 22.5 & 23.6 & 26.3 \\
\hline Unemployment rate (percent) & 26.2 & 26.7 & 25.5 & 23.0 & 22.9 \\
\hline National government budget balance (percent of GDP) ${ }^{3}$ & -1.6 & -0.6 & 0.4 & 0.9 & 0.5 \\
\hline National government debt (percent of GDP) ${ }^{3}$ & 36.4 & 35.3 & 33.1 & 28.6 & 25.6 \\
\hline External current account balance (percent of GDP) & -3.2 & -4.0 & -6.5 & -7.3 & -9.0 \\
\hline External debt (percent of GDP) & 20.8 & 19.1 & 22.2 & 26.6 & 29.6 \\
\hline Gross reserves (SARB, in months of next year's total imports) & 2.6 & 2.9 & 3.1 & 3.2 & 3.3 \\
\hline International liquidity position of SARB (billions of U.S. dollars) ${ }^{2}$ & 11.4 & 17.2 & 23.0 & 31.3 & 34.9 \\
\hline U.S. dollar exchange rate (rand per U.S. dollar) ${ }^{2}$ & 5.63 & 6.33 & 6.97 & 6.81 & $\ldots$ \\
\hline
\end{tabular}

Sources: South African Reserve Bank; IMF, International Financial Statistics; and staff estimates and projections.

${ }^{1}$ The CPIX is equal to the CPI excluding interest payments on mortgage loans.

${ }^{2}$ End of period.

${ }^{3}$ Calendar year. 


\section{Statement by Peter Gakunu, Executive Director for South Africa and Goolam Aboobaker, Senior Advisor to Executive Director September 8, 2008}

\section{Introduction}

1. The South African authorities find the Article IV report a fair reflection of their discussions with the Fund staff. They agree with the broad thrust of the Staff appraisal. They find the FSAP Update to be thorough and are in broad agreement with the recommendations contained therein.

\section{Recent Economic Developments}

2. After several years of robust, above-trend economic growth of about 5 percent, real GDP growth has slowed down in 2008. GDP growth in the first quarter slowed to 2.1 percent having been badly affected by serious electricity supply disruption that affected both mining and manufacturing output. However, second quarter data indicate a significant rebound, pushed by mining, agriculture, manufacturing, and construction, with an annualized growth rate of 4.9 percent in Q2. A star performer in the first half has been gross fixed capital formation (GFCF), which accelerated at 16.9 percent q/q in Q1. Although it slowed to 9.1 percent in Q2, if the trend continues, GFCF would push potential growth into a higher trajectory for the medium term.

3. South Africa has not been immune to the inflationary pressure arising mainly from increases in global food and oil prices. Inflation has continued to rise with CPIX inflation reaching 13 percent in July $2008 \mathrm{y} / \mathrm{y}$ and is expected to peak later this year before beginning a downward trajectory. The South African Reserve Bank has acted decisively by tightening monetary policy in order to dampen inflationary pressures and to counter second round effects as well as inflationary expectations. The repurchase rate has risen by a cumulative 500 basis points (bps) since June 2006. This has brought down retail sales and household consumption continues to decelerate. Recent data indicate that private sector credit extension has also begun to moderate.

4. Results released from the latest quarterly labor force survey indicate that the economy has continued to create employment and show that in the first quarter of 2008 the level of formal non-agricultural employment increased by 3.9 percent. However, the unemployment rate, standing at about 23 percent, remains high. Of particular concern is the unemployment rate amongst the youth $(15-24$ years) which is recorded at over 40 percent. The authorities consider appropriate measures to tackling this problem a priority.

5. In the context of slow employment growth and widespread poverty, the authorities continue to rely on social transfers to ensure that benefits of economic growth are shared equitably. Recent data indicate that the roll out of social security grants, principally child 
support grants and old age pensions, increased to a total of 12.4 million beneficiaries. Social transfers comprise 3.1 percent of GDP. There has also been a significant decrease in the number of people living below the various poverty lines. However, while the income of all sectors of the population has increased, the level of inequality has remained high.

6. Preliminary estimates indicate a widening of the current account deficit in the first quarter of 2008 to 8.9 from 7.3 percent for 2007 but a narrowing back to 7.3 percent in the second quarter largely because exports increased by 20 percent. Nonetheless, the concerns about the size of the deficit remains, underpinning the need to accelerate exports and increase savings as indicated in several statements by the authorities. However, we need to reiterate an observation contained in a recent survey of the South African economy by the OECD that this "deficit does not correspond to public dissaving, but to private savings-investment behavior." The pressure on the current account has come largely from the public and private sector investment program with significant import components. Moreover, South Africa's external debt at 26.6 percent of GDP in 2007 remains low.

\section{Fiscal Policy}

7. The authorities remain committed to fiscal prudence. Their 2008 consolidated national budget made provision for a surplus of 0.8 percent of GDP, with slightly declining surpluses in 2009 and 2010. The authorities also made provision for a public sector borrowing requirement of 1.3 percent of GDP over the MTEF period to ensure that financing requirements of state owned enterprises, municipalities, and other public entities are met.

8. The authorities agree that the downside risk posed by a widening of the current account deficit is a serious concern, especially in light of current developments in the global economic environment. The staff suggestion of a significant improvement in government savings is in line with the authorities' thinking; and will remain an important objective of fiscal policy into the foreseeable future. However, the authorities remain uncertain as to the desirability of increasing savings at the pace recommended by the staff. The concern is that while the suggested government savings may be expected to improve the current account, it would not significantly relieve the financing concerns of the economy as a whole. In addition, in the short term this would require significant increase in the tax burden or reduction in consumption expenditure (short-term opportunities for efficiency gains are limited), the net effect on the economy and broader economic environment of such an aggressive increase in government savings could in fact be negative. The authorities agree with staff that low savings rate is a key constraint on increasing investment on a sustained basis. This is a recurring theme that the authorities regularly articulate through public statements.

9. The authorities have noted the serious decline in corporate savings which appears to correlate with the increase in revenue. However, they are uncertain that in order to boost corporate savings, the corporate income tax rate has to be reduced further. While the 
corporate tax rate was reduced from 35 percent in 1996 to 29 percent in 2007, corporate savings declined.

\section{Monetary policy}

10. Inflation outlook has deteriorated as a result of a combination of factors depreciation of the South African Rand against USD and other major currencies, the upward revisions in oil prices and administered prices. The SARB has responded to the deterioration in inflation by increasing the repo rate by a cumulative 500 bps since June 2006 resulting in an increase in money market rates. The authorities agreed on the importance of clear communication of their inflation targeting approach to combating inflation and its expectations.

11. The ZAR depreciated by 11.9 percent against the US\$ at end-August 2008 mainly because of risk aversion among global investors, bigger current account deficit and the expected impact of electricity supply constraints on economic growth. The daily turnover of foreign exchange against the ZAR in domestic foreign exchange market has also seen an increase, reaching a peak of US\$ 14.4 billion at the end of 2007. There has also been a significant increase in the volatility of the ZAR's exchange rate, reaching a high of 28.2 percent before declining to 17.0 percent. International reserves at end July 2008 stood at US\$ 35 billion and the Authorities remain committed to increasing reserves which currently are adequate to cover 3.2 months of imports of goods and services

12. The authorities reaffirm their commitment to the flexible exchange rate system as it continues to serve them well and have noted the conflicting results produced by Fund methodologies regarding its value.

13. The Johannesburg Stock Exchange (JSE), the local equity bourse, has seen an increase in equity prices of about 45 percent since the end of 2005 driven largely by high commodity prices, positive performances in corporate sector, healthy economic growth as well as merger and acquisition activity. Since the end of 2007, it has declined by under 10 percent (September 4, 2008). Despite the turmoil in global financial markets, the South African economy and the JSE have continued to attract net capital inflows demonstrating economy's resilience. In Q2 there was a net inflow of R44.7 billion, with a large portion being portfolio investments. However, the authorities are monitoring these developments to take the necessary actions to deal with downside risks.

\section{Financial sector}

14. The South African financial system is sound, underpinned by a well-established legal and financial infrastructure, and an effective and modern regulatory framework. The system, amidst the current global financial market turmoil, has remained largely unaffected and strong. 
15. There has been a sharp increase in non performing loans, but from a very low base and at end of 2007 stood at 1.4 percent. A significant percentage of NPLs are mortgage related. Debt service cost to disposable income increased from 11.3 percent in first quarter to 11.6 percent in the second. The authorities share staff concerns regarding the elevated debt service burden affecting households but would like to add that NPLs remain low in comparison to other EMs. They also agree with Staff suggestion that it would be important to have a better understanding of the distribution of household debt and debt service costs by income category. Meanwhile the authorities are monitoring the situation and encouraging financial institutions to take appropriate prudential measures.

\section{Structural reforms and Accelerated and Shared Growth Initiative of South Africa (ASGISA)}

16. The authorities are aware that the key challenge confronting the country is how to strengthen growth and employment; and in meeting this challenge serious structural reforms, including in labor and product markets, have been considered. This was the principal reason for launching ASGISA.

17. Alongside the launch of the ASGISA, the authorities appointed an international panel of notable economists to undertake an examination of the constraints to faster economic growth and advise the government on how to accelerate growth so as to halve poverty and unemployment by 2014. The panel completed its investigation and its report was publicly released earlier this year so as to generate debate. The Panel's broad conclusion is that the key challenge confronting authorities in employment creation is how to develop/promote the tradable sector of the economy so as to absorb semi-skilled and unskilled workers to produce for export markets. This would help to reduce unemployment.

18. The recommendations of the panel, informed by a series of policy papers, are far reaching and cover wide policy areas. Their recommendations include measures to respond to volatility of the exchange rate, how to address low national savings, the need to introduce a wage subsidy to encourage the employment of youth between 16-24 years (school leavers), tariff reform and a proactive competition policy in order to reduce barriers to entry, etc.

\section{Conclusion}

19. The authorities remain steadfast in their commitment to formulating and implementing sound policies to ensure macroeconomic stability and robust growth to facilitate poverty reduction. 